Illinois State University

ISU ReD: Research and eData

Theses and Dissertations

$10-6-2013$

\title{
An Examination of Student Perceptions of Regional Safe School and Public School Services
}

Elizabeth Degruy

Illinois State University, elizabethdegruy@hotmail.com

Follow this and additional works at: https://ir.library.illinoisstate.edu/etd

Part of the Special Education Administration Commons, and the Special Education and Teaching Commons

\section{Recommended Citation}

Degruy, Elizabeth, "An Examination of Student Perceptions of Regional Safe School and Public School Services" (2013). Theses and Dissertations. 22.

https://ir.library.illinoisstate.edu/etd/22

This Dissertation is brought to you for free and open access by ISU ReD: Research and eData. It has been accepted for inclusion in Theses and Dissertations by an authorized administrator of ISU ReD: Research and eData. For more information, please contact ISUReD@ilstu.edu. 
AN EXAMINATION OF STUDENT PERCEPTIONS OF REGIONAL SAFE

SCHOOL AND PUBLIC SCHOOL SERVICES

\author{
Elizabeth J. deGruy
}

213 Pages

May 2011

This study involved the analysis of the perceptions of students with disabilities who attend a regional safe school of their schooling experiences. Findings indicate that students identify both teacher and school factors as contributing to their success.

APPROVED:

Date Maureen E. Angell, Chair

Date Julia B. Stoner

Date James R. Thompson

Date Elizabeth T. Lugg 


\title{
AN EXAMINATION OF STUDENT PERCEPTIONS OF REGIONAL SAFE SCHOOL AND PUBLIC SCHOOL SERVICES
}

\author{
Elizabeth J. deGruy
}

213 Pages

May 2011

The purpose of this study was to investigate the perceptions of students with Individualized Education Programs who attend regional safe schools of their educational experiences. The Individuals with Disabilities Education Act mandates that students with disabilities be provided a free, appropriate, public education in the least restrictive environment; however, the students who participated in this study had been removed from their home public schools. This study employed a qualitative research methodology to investigate the students' perspectives on their experiences at public schools and a regional safe school.

Participants in this study were 8 high school students with disabilities who attended a regional safe school. The school was located in a small urban community in the Midwest. Data were collected through document review, observations, and one-onone, semi-structured interviews. All but one student participated in three interviews. Interview questions focused on students' experiences, views of their success in public and alternative school, and elements that they identified as being essential for their success. Open coding was used to analyze student responses to interview questions. 
Findings indicated that students identified both teacher and school factors as essential to their school success. Students expressed positive changes in themselves in the areas of motivation, determination to succeed, and self-awareness. All students perceived that they were more successful at their regional safe school.

APPROVED:

$\overline{\text { Date } \quad \text { Maureen E. Angell, Chair }}$

Date Julia B. Stoner

Date James R. Thompson

Date Elizabeth T. Lugg 
AN EXAMINATION OF STUDENT PERCEPTIONS OF REGIONAL SAFE SCHOOL AND PUBLIC SCHOOL SERVICES

ELIZABETH J. DEGRUY

A Dissertation Submitted in Partial Fulfillment of the Requirements for the Degree of

DOCTOR OF EDUCATION

Department of Special Education

ILLINOIS STATE UNIVERSITY 
AN EXAMINATION OF STUDENT PERCEPTIONS OF REGIONAL SAFE SCHOOL AND PUBLIC SCHOOL SERVICES

\section{ELIZABETH J. DEGRUY}

DISSERTATION APPROVED:

\begin{tabular}{ll}
\hline Date & Maureen E. Angell, Chair \\
\hline Date & Julia B. Stoner \\
\hline Date & James R. Thompson \\
\hline Date & Elizabeth T. Lugg
\end{tabular}




\section{ACKNOWLEDGMENTS}

As with all who have navigated this process, I am sure, the completion of this program is not my accomplishment alone. I wish to thank members of my dissertation committee, my family, and my friends who have supported me and made the completion of my doctoral program a reality. First, I thank Dr. Maureen Angell for serving as the chair of my committee, a responsibility representing the culmination of 4 years of support and mentoring, prodding, encouragement, and inspiration. Thank you for the many times you have put me back on track while allowing me to think that I found my own way. Thank you to my committee members, Dr. Julia Stoner, Dr. James Thompson, and Dr. Elizabeth Lugg for your time, expertise, and support. Thank you for exciting me about the possibilities of qualitative research, education law, and precision in my work.

To my family, thank you for always believing that I could reach this goal. Mom and Dad, thanks for your moral and financial support, your prayers, and your pride in me. Yes mother, I did finish before you were dead. To Ann, Catherine, and Michael, thank you for your encouragement and for not telling me what you really think of me during this process.

To my friends, thank you for putting up with this experience and remaining my friends. To Apryl Whitehead, my oldest and dearest friend who took my calls in the middle of the night and offered me escape to Las Vegas; to April Westerfield, who got me into this in the first place and has been my greatest cheerleader; and to Joanna Nicholson, to whom I am forever bonded by shared suffering, words cannot express my 
appreciation. Thank you to Donna Kauffman for all of the help you have given me, particularly for having enthusiasm for this project that exceeded mine on the days that I needed it. Angela Bell, Amy and Sean Wells, Gregory Hall, Lori Busboom, Rick Carr, Cindy Keller, Katie Ahsell - thank you for your friendship and encouragement even when I was painful to be around.

Thank you to the Urbana and Champaign School Districts for providing me with rich professional experiences, learned mentors, and dear friends. Many thanks to those who have supported me through the daily neuroses involved in completing a doctoral program, Tish Stanner, Agatha Barnes, Katey Haun, Kay Sathoff, Melissa Vessell, Sarah Evans, Beth Ladd, Theresa Sweeney, Liza Thomas, and Terence Fitzgerald. Last, thank you to all the unnamed teachers and students with whom I have worked. I have learned significantly more from you than I have taught.

E. J. deG. 


\section{CONTENTS}

ACKNOWLEDGMENTS

CONTENTS

TABLES

FIGURES

\section{CHAPTER}

I. INTRODUCTION

Historical and Contemporary Conceptualization of LRE

Deno's (1970) Cascade and the Continuum of Placements

Dissatisfaction with Separate Placements

Current Status of Placements

National and state data

Speech and language impairments

Learning disabilities

Other health impairments

Autism spectrum disorder

Intellectual disabilities

Emotional disabilities

Mainstreaming, REI, and Inclusive Education Movements and LRE 
Statement of the Problem 31

Significance of the Study $\quad 32$

Purposes of the Study

Research Questions 33

Definitions of Terms $\quad 34$

Assumptions $\quad 35$

Delimitations $\quad 35$

Limitations $\quad 35$

Chapter Summary $\quad 36$

II. REVIEW OF RELATED LITERATURE AND RESEARCH 37

Methods for Conducting the Search for Related Literature 37

Results of Literature Review $\quad 38$

History and Definition of Alternative Schools 38

National Studies $\quad 40$

State Legislation $\quad 41$

$\begin{array}{ll}\text { Students Served } & 47\end{array}$

$\begin{array}{ll}\text { Curriculum } & 47\end{array}$

Special Education and Alternative Schools 48

$\begin{array}{ll}\text { Surveys } & 51\end{array}$

Alternatives to the Alternative School 52

Charter schools $\quad 54$

Regional Safe Schools $\quad 56$

Public-private partnerships $\quad 56$

Therapeutic schools 57

Residential schools $\quad 58$

Interim alternative educational settings $\quad 60$

$\begin{array}{lr}\text { Student Perspectives } & 60\end{array}$ 
$\begin{array}{ll}\text { Purpose of the Study } & 67\end{array}$

$\begin{array}{ll}\text { Research Questions } & 68\end{array}$

Research Design $\quad 68$

$\begin{array}{ll}\text { Sampling Plan } & 70\end{array}$

Researcher as Instrument $\quad 71$

$\begin{array}{ll}\text { Participants } & 72\end{array}$

School Participants Attended $\quad 72$

$\begin{array}{ll}\text { Eligibility Criteria } & 73\end{array}$

$\begin{array}{ll}\text { Recruitment } & 73\end{array}$

Selection of Participants $\quad 74$

$\begin{array}{ll}\text { Participant Descriptions } & 74\end{array}$

Thomas $\quad 75$

$\begin{array}{ll}\text { Evan } & 76\end{array}$

Bobby $\quad 77$

Zach $\quad 78$

Luke $\quad 79$

$\begin{array}{ll}\text { Isaiah } & 80\end{array}$

Hailey $\quad 81$

$\begin{array}{ll}\text { Andrea } & 81\end{array}$

$\begin{array}{ll}\text { Data Collection } & 82\end{array}$

Generation of Document Data $\quad 82$

Generation of Observation Data $\quad 83$

Generation of Interview Data 84

Data Management and Analysis $\quad 85$

$\begin{array}{ll}\text { Confirmability } & 87\end{array}$

Role of the Researcher $\quad 88$

Ethical Considerations $\quad 89$

$\begin{array}{ll}\text { Chapter Summary } & 90\end{array}$

$\begin{array}{ll}\text { IV. FINDINGS } & 91\end{array}$ 
Results of Documents Review

Websites $\quad 92$

Student Handbook $\quad 92$

Master Schedule $\quad 93$

FY 2010 End Year Report 93

Findings from Observations 994

Clear Expectations $\quad 96$

Student-Centered Environment $\quad 97$

Strong Student-Teacher Relationships $\quad 100$

Findings from Interviews 103

Concept Map of Interview Findings 103

Teacher Factors: Disposition $\quad 105$

Understanding 105

Caring 106

Accessible 112

Interest in students' lives outside of school 115

Teacher Factors: Knowledge and Skills 117

Explains academic content well 117

Follows up $\quad 119$

$\begin{array}{ll}\text { School Factors: Structure } & 120\end{array}$

Small class size $\quad 120$

Clear student limitations $\quad 123$

$\begin{array}{ll}\text { School Factors: Culture } & 124\end{array}$

Family environment $\quad 124$

Student accountability $\quad 125$

$\begin{array}{ll}\text { Motivation systems } & 126\end{array}$

$\begin{array}{ll}\text { Changes in Students } & 128\end{array}$ 
Findings Related to Research Question One

Teachers who care

Teachers who are willing to help when needed

Structure

Culture

Findings on School Factors: Addressing the Research Questions 161

Key Findings Related to Changes in Students

Motivation

Determination to Succeed 
$\begin{array}{ll}\text { Conceptual Framework } & 167\end{array}$

Limitations of the Study 168

Implications for Practice 169

Recommendations for Future Research 172

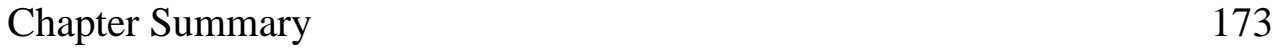

$\begin{array}{ll}\text { REFERENCES } & 174\end{array}$

APPENDIX A: Initial Interview Protocol 191

APPENDIX B: Second Interview Protocols 192

APPENDIX C: Third Interview Protocols 206 


\section{TABLES}

Table Page

1. Case Law on Least Restrictive Environment 8

2. Participant Demographics 75

3. Observations 95 


\section{FIGURES}

Figure

1. Concept Map of Major Findings and Themes
Page

104 


\section{CHAPTER I}

\section{INTRODUCTION}

Thomas Jefferson wrote of the importance of "an enlightened citizenry" and that the government should undertake to "educate and inform the whole mass of the people" (1789). While the mass of which Jefferson wrote is not the mass that is educated today, his ideals have been touted by and applied to various groups of people seeking educational rights. If it is in the public interest to have citizens educated, then surely this means all citizens should be educated.

In Brown v. Board of Education (1954), the Supreme Court agreed, holding that not only should all citizens be afforded the property right of an education, but that the education should not be separate based on race. The Fifth and Fourteenth Amendments (U.S. Const., amend. V, § 1; U.S. Const., amend. XIV, § 1) mandated due process and equal protection under the law, and this applied to an equal education. While this case did not address the rights of people with disabilities, the arguments set forth in Brown would be applied to students with disabilities in fewer than 20 years.

\section{P.A.R.C. v. Commonwealth of Pennsylvania (1971) and Mills v. Board of}

Education (1972), Supreme Court cases holding that students with disabilities were entitled to due process and free public education in an environment similar to that of their non-disabled peers, prepared the country for the mandate that all children with disabilities would be educated at the expense of the state. The passage of the Education for All Handicapped Children Act of 1975 (P.L. 94-142) recognized that certain students required special education and related services in order to access public education, and 
these students were those who qualified as students with disabilities under the law. The idea that separate was not equal for people with disabilities was reinforced.

In the years since the passage of P.L. 94-142, the categories of disabilities that might qualify students for special education services have expanded. Today, the categories in which students may qualify for special education and related services are the following: autism spectrum disorder (ASD), deaf-blindness, deafness, developmental delay, serious emotional disturbance (ED), hearing impairment, intellectual disability, multiple disabilities, orthopedic impairment, other health impairment (OHI), specific learning disability (SLD), speech or language impairment (S/L), traumatic brain injury, and visual impairment. Operational criteria for these disability categories have been defined by federal and state law as well as local school districts. In order to meet the eligibility criteria for special education, a student must have a disability in one of the listed areas and that disability must have an adverse effect on the student's education, requiring special education and related services (Hardman, Egan, \& Drew, 2008).

P.L. 94-142 outlined the ideal of the Least Restrictive Environment (LRE), the federal mandate that

To the maximum extent appropriate, children with disabilities... are educated with children who are not disabled, and that special classes, separate schooling, or other removal of children with disabilities from the regular [general] education environment occurs only when the nature or severity of the disability is such that education in regular classes with the use of supplementary aids and services cannot be achieved satisfactorily (Individuals with Disabilities Education Act [IDEA], 2004, PL 108-446, Sec. 614[d]).

The LRE mandate required school districts to develop and maintain a continuum of placements where students with disabilities might be educated, making substantial efforts to educate students with disabilities in the same settings as students without disabilities. 


\section{Historical and Contemporary Conceptualization of LRE}

\section{Deno's (1970) Cascade and the Continuum of Placements}

Prior to the passage of P.L. 94-142 in 1975, schools struggled with how and where to educate students with disabilities. As part of an article decrying the existing categorical system of special education, Deno (1970) proposed a cascade model of services. This model emphasized the responsibility that both the general and special education systems had to educate students with disabilities and was "designed to make available whatever different-from-the-mainstream kind of setting is required to control the learning variables deemed critical for the individual case...tailoring of treatment to individual needs" (p. 235). Deno's cascade was represented by a large inverted triangle wherein the largest number of students would receive educational services in the regular classroom. As the triangle tapered, the six levels of educational settings became more segregated, until reaching the tip, in which was located homebound services. This large triangle sat atop a smaller triangle which included residential or hospital settings, what Deno termed health or welfare placements. Interestingly, even while proposing options ranging from regular education classrooms to highly segregated settings as part of the continuum of placements, Deno questioned whether or not the general and special education systems should be separate.

Other authors have agreed with the need for multiple educational placement options for students with disabilities. Vergason and Anderegg (1992) defined the LRE as "an instructional environment independent of setting" (p. 45). That is, the LRE was the environment that could best meet the needs of a student with a disability and best prepare him or her for life after school. By virtue of the differences in children, this was indi- 
vidualized and necessitated a continuum of placements. MacMillan (1977) described the continuum of placements for students with intellectual disabilities, who need multiple options for placement because of their varying needs. The need for specialized instruction, an alternate curriculum, intensive school and adult services, and a similar peer group required special education placements for some students with disabilities (Lieberman, 1992). Merulla and McKinnon (1982) called for greater flexibility in program planning for students who seemed to get stuck at certain service levels of Deno's (1970) cascade, noting that special education over-serves some students and under-serves others. Zigmond and Baker (1995) stated that instruction, not location, should be the most important consideration in the education of students with disabilities. Indeed, while researchers have debated the merits of separate placements, it is notable that the debate has always been about special education services and instruction, "the intensity and effective delivery of which sometimes requires a change in the place of instruction" (Hockenbury, Kauffman, \& Hallahan, 1999-2000, p. 5). The Council for Exceptional Children (1995) agreed with the need for educational placement options, publishing the position statement that "full-inclusion" for students with learning disabilities was not supported by research or by the mandate to address students' needs individually.

In other studies, residential settings, the most restrictive placements for students with disabilities, have yielded benefits for some students with emotional disabilities (Farrell \& Polat, 2003; Gelder, Sitlington, \& Pugh, 2008). Last, in spite of the myriad recommendations for improving the inclusion of students with emotional disturbance, Kauffman and Lloyd (1995) asserted that, "we doubt that regular schools and classrooms will ever be able to provide an appropriate education for all students with emotional or 
behavioral disorders" (p. 542). Advocates of children with hearing and vision impairments supported separate placements for these children because of the instructional specialization needed and the cultural experiences not available in the general education classroom (Fuchs \& Fuchs, 1994). Last, Lieberman (1992) made an important point, noting that, "To be against full integration as public policy, or educational or school policy, is not to be for exclusion" (p. 15). The supporters of the continuum of placements were not against the placement of students with disabilities in regular classrooms; they were against that as the only option.

\section{Dissatisfaction with Separate Placements}

When discussing full inclusion in general education classrooms for students with intellectual disabilities, Brown et al. (1991) asserted that "the 100\% club may not have a member" (p. 40); however, other authors have noted that $100 \%$ is preferable to $0 \%$. Indeed, the $100 \%$ club has had many members. Prior to the passage of P.L. 94-142, Dunn (1968) questioned the value of separate placements for students with disabilities, noting that "we must stop segregating them by placing them into our allegedly special programs" (p. 6) and advocated for the end of special education classrooms. Dunn further explained that labels were damaging to students with disabilities, who were further hurt by special education's homogeneous groupings. MacMillan (1977) noted that, "It is naïve to assume that physical mainstreaming (the simple placement of the child in the class) will result in immediate success" (pp. 452-453); however, the general education classroom was the preferred placement for students with intellectual disability. Reynolds (1989) argued that "there was no evidence in the past and there is no evidence now showing that removing disabled children from the mainstream and putting them into 
special classes or schools is an advantage for them" (p. 8). Full inclusion was touted as a means for students with disabilities to make greater academic and social gains and to prepare them for community living; it could also help nondisabled peers gain understanding of people with disabilities (Stainbeck \& Stainbeck, 1992). The Regular Education Initiative (REI) and inclusive education movements, discussed in greater detail below, advocated for the end of the segregation that occurs through special education (Kavale \& Forness, 2000). The inclusive education movement in particular has had unyielding $100 \%$ members, led by advocates of people with severe disabilities.

\section{Current Status of Placements}

The Individuals with Disabilities Education Act (IDEA, 2004) outlined three steps to be followed by Individualized Education Program (IEP) teams when determining a student's placement in special education (Yell \& Katsiyannis, 2004). Teams need to consider the evaluation and identification and determine the student's educational needs. Next, teams must develop the student's IEP, including the student's measurable goals and how they will be reached. The third step, based on the data compiled from the first two steps, was to decide the most appropriate placement for the child. Although the student's educational needs drive placement, the effect of the student on peers may also be considered, as documented in the legislation and case law I discuss in later sections. Schools must define their continuum of placements, which IEP teams must consider in order of least to most restrictive. The IDEA outlined that the continuum must include the general education classroom, special classes, special schools, homebound instruction, and instruction in institutions and hospitals. Teams must consider not only the continuum of placements that is available, but how supplementary aids and services might allow 
students to be placed in less restrictive settings, and where opportunities for greater integration might exist. Districts and states continue to struggle with placement of students with disabilities, particularly with maximizing their time in the general education environment.

Although the considerations in making placement decisions are the same for all IEP teams, the individual characteristics of students differ considerably, affecting team decisions. For example, specific disabilities and their severity levels may make certain placements more or less acceptable to IEP teams. Students may not be placed according to disability, as noted in Corey H. v. Board of Education of the City of Chicago (1998; see Table 1); however, there are placements that are geared toward certain populations. In particular, therapeutic day schools and residential placements, which are often private placements, may be designed to meet the needs of specific students. However, schools are to consider these placements only after IEP teams determine that the general education environment, home schools, and home districts are unable to meet students' needs. 
Table 1

Case Law on Least Restrictive Environment

\begin{tabular}{|c|c|c|c|c|}
\hline Name & Citation & Rule of Law & Material Facts & Decision \\
\hline $\begin{array}{l}\text { Board of } \\
\text { Education of } \\
\text { the Hendrick } \\
\text { Hudson Central } \\
\text { School District } \\
\text { v. Rowley } \\
(6 / 28 / 1982)\end{array}$ & $\begin{array}{l}458 \text { U.S. } \\
176\end{array}$ & $\begin{array}{l}\text { Defined FAPE as } \\
\text { providing a "basic } \\
\text { floor of opportunity" } \\
\text { consistent with equal } \\
\text { protection. The } \\
\text { requirement for FAPE } \\
\text { is met when the school } \\
\text { provides } \\
\text { individualized } \\
\text { instruction with } \\
\text { support services to } \\
\text { permit the child with a } \\
\text { disability to benefit } \\
\text { educationally from } \\
\text { that instruction. }\end{array}$ & $\begin{array}{l}\text { A deaf student in a } \\
\text { public school sued } \\
\text { local officials } \\
\text { claiming a denial of } \\
\text { FAPE because the } \\
\text { district did not } \\
\text { provide the student } \\
\text { with a qualified sign- } \\
\text { language interpreter } \\
\text { in all of her academic } \\
\text { classes. }\end{array}$ & $\begin{array}{l}\text { The Act's require- } \\
\text { ment of a "free } \\
\text { appropriate public } \\
\text { education" is satis- } \\
\text { fied when the State } \\
\text { provides personal- } \\
\text { ized instruction with } \\
\text { sufficient support } \\
\text { services to permit the } \\
\text { handicapped child to } \\
\text { benefit educationally } \\
\text { from that instruction. } \\
\text { The Act does not } \\
\text { require a state to } \\
\text { maximize the poten- } \\
\text { tial of each handi- } \\
\text { capped child com- } \\
\text { mensurate with the } \\
\text { opportunity provided } \\
\text { nonhandicapped } \\
\text { children. }\end{array}$ \\
\hline $\begin{array}{l}\text { Honig v. Doe } \\
(1 / 20 / 1988)\end{array}$ & $\begin{array}{l}484 \text { U.S. } \\
305\end{array}$ & $\begin{array}{l}\text { "Stay-put" provision } \\
\text { of the EHA prohibited } \\
\text { state or local school } \\
\text { authorities from } \\
\text { unilaterally excluding } \\
\text { disabled children from } \\
\text { classroom for danger- } \\
\text { ous or disruptive con- } \\
\text { duct growing out of } \\
\text { their disabilities during } \\
\text { pendency or review } \\
\text { proceeding. A suspen- } \\
\text { sion in excess of } 10 \\
\text { days does constitute a } \\
\text { prohibited "change in } \\
\text { placement." }\end{array}$ & $\begin{array}{l}\text { Emotionally } \\
\text { disturbed students } \\
\text { were suspended } \\
\text { indefinitely for } \\
\text { violent and disruptive } \\
\text { conduct related to } \\
\text { their disabilities, } \\
\text { pending the } \\
\text { completion of } \\
\text { expulsion } \\
\text { proceedings by the } \\
\text { San Francisco } \\
\text { Unified School } \\
\text { District. }\end{array}$ & $\begin{array}{l}\text { Case was moot for } \\
\text { one of the students, } \\
\text { who was already } 24 \\
\text { years old. There is a } \\
\text { presumption in favor } \\
\text { of the student's } \\
\text { current placement } \\
\text { ("stay put"). Schools } \\
\text { may not remove } \\
\text { students unless they } \\
\text { show that the } \\
\text { placement is } \\
\text { substantially likely to } \\
\text { result in injury to self } \\
\text { or others. }\end{array}$ \\
\hline $\begin{array}{l}\text { M.R. } v . \\
\text { Lincolnwood } \\
\text { Board of } \\
\text { Education, } \\
\text { District } 74 \\
(2 / 1 / 1994)\end{array}$ & $\begin{array}{l}\text { No. } 93 \text { C } \\
0418\end{array}$ & $\begin{array}{l}\text { Level of student } \\
\text { disruption in } \\
\text { placement is a factor } \\
\text { to be considered in } \\
\text { appropriateness of } \\
\text { placement. }\end{array}$ & $\begin{array}{l}\text { A student with } \\
\text { disruptive behavior } \\
\text { was placed at a } \\
\text { therapeutic day } \\
\text { program. Parent } \\
\text { argued that he was } \\
\text { benefitting from his } \\
\text { public school } \\
\text { placement. }\end{array}$ & $\begin{array}{l}\text { The placement was } \\
\text { in the therapeutic day } \\
\text { treatment facility was } \\
\text { upheld. }\end{array}$ \\
\hline
\end{tabular}


Table 1 (continued)

\begin{tabular}{lll}
\hline Name & Citation & Rule of Law \\
\hline $\begin{array}{l}\text { Board of } \\
\text { Education of }\end{array}$ & 41 F.3d & $\begin{array}{l}\text { As the school district } \\
\text { failed to present an }\end{array}$ \\
$\begin{array}{l}\text { Murphysboro } \\
\text { Community }\end{array}$ & $\begin{array}{l}\text { IEP that met the } \\
\text { requirements of IDEA } \\
\text { Unit School }\end{array}$ & $\begin{array}{l}\text { and had suggested no } \\
\text { District No. }\end{array}$ \\
186 v. Illinois & $\begin{array}{l}\text { alternatives, the court } \\
\text { placed the child as }\end{array}$ \\
Education & urged by the parents. \\
(12/5/1994) & & Mainstreaming is \\
& & applicable only if the \\
& & IEP meets the other \\
& & IDEA requirements.
\end{tabular}

Corey H. v. The $995 \mathrm{~F}$.

Board of

Education of

the City of

Chicago

(2/19/1998)
A.S. v. Five

Town

Community

School District

(1/18/2008)
Supp. 900

The failure of the

Board of Education of

the City of Chicago

also belonged to the

Illinois State Board of

Education. The State

Board was responsible

for monitoring of LRE

and had made no

efforts to enforce or

remediate violations of

LRE.

513 F.3d

279

Court could not reject adequate public school
Material Facts

A student with intellec- Since the residential tual disability, speech and language impairments, and possibly ASD was recommended by her district there.

for a placement that included interaction with non-disabled peers. Parents argued that the placement did not meet her educational needs, withdrew her from public school, and continued to request residential placement.

Children with disabilities in the Chicago public schools had been segregated into separate and unequal educational environments, contrary to established federal law. Students were placed by category of disability rather than with the intention of educating them in the LRE. placement for optimal private placement. A school system has met the obligation for FAPE as long as the program that it offers to a disabled student is "reasonably calculated" to deliver "educational benefits." facility was the only viable option, the court ordered that the child be educated
Placements decisions must based on the child's individual needs as determined by his or her IEP. Placements should be in the LRE rather than categorical programs.

Reimbursement of parents' expenses was denied as they abandoned the collaborative IEP process before an appropriate IEP could be written.
Parents of a student with an emotional disability placed her in a private school before the school district could evaluate the student. After completion of private evaluation, an IEP was proposed. The school district and private evaluator agreed that a public placement was appropriate. Parents disagreed, placed residentially again, and requested reimbursement. 


\begin{tabular}{|c|c|c|}
\hline Name & Citation & Rule of Law \\
\hline $\begin{array}{l}\text { Christina } \\
\text { McComish v. } \\
\text { Underwood } \\
\text { Public Schools } \\
(3 / 6 / 2008)\end{array}$ & $\begin{array}{l}2008 \text { U.S. } \\
\text { Dist. } \\
\text { LEXIS } \\
17492\end{array}$ & $\begin{array}{l}\text { Continuing to educate } \\
\text { Christina in the } \\
\text { District without } \\
\text { providing FAPE } \\
\text { simply because it is } \\
\text { the LRE would run } \\
\text { contrary to the } \\
\text { mandate of the IDEA. }\end{array}$ \\
\hline
\end{tabular}

Material Facts

Decision

Student with a

Because South

significant visual

impairment was

placed at a public

high school with

services from a low-

vision instructor.

After the teacher

resigned, the district

was unable to replace

her. Other placements

were explored, but

only the SDSB could

meet her needs.

Stevie Yates v.

2008 U.S. The $9^{\text {th }}$ Circuit relied

Stevie was a high school student with

Washoe County Dist.

on a four factor

School District

LEXIS

$(8 / 28 / 2008)$

68937

balancing test for

LRE: (a) the

educational benefits of

placement full-time in

a regular class, (b)

non-academic benefits

of the placement, (c)

the effect of the

student on the teacher

and other students, and

(d) the cost of

mainstreaming.

ASD and apraxia,

who had not devel-

oped functional

verbal skills. Parents

alleged that Stevie's

placement in a spe-

cial education math

class, in addition to

his special education

English and voca-

tional classes, con-

stituted a violation of

FAPE in the LRE.

Also complaints

about lack of inclu-

sion of BIP and

assistive technology

in the IEP.

Stevie's receipt of math instruction in the special education resource room is consistent with

IDEA's LRE

mandate.

The educational benefits available to

Stevie in the math

resource room

outweigh the

educational benefits

to him through

embedded activities

in the general

education

environment. The

district did not

violate FAPE.

M.W. v. Clarke

2008 U.S.

Plaintiffs bear the

Preschool student burden of showing that

County School

Dist.

District

LEXIS

(a) Defendant's

with ASD was placed

in a self-contained

placement was

inappropriate and (b)

Their chosen

classroom for

students with ASD.

Parents requested

placement was

appropriate.

multiple evaluations

and eventually

removed M.W. from

the public school and

enrolled him in

private school.

Since the defendant

does not have its own

public school

program for non-

disabled three year-

old students, within

the continuum of

services provided

directly by the

defendant, M.W. was

in the LRE.

Table 1 (continued) 


\begin{tabular}{|c|c|c|c|c|}
\hline Name & Citation & Rule of Law & Material Facts & Decision \\
\hline $\begin{array}{l}P . v . \text { Newington } \\
\text { Board of } \\
\text { Education } \\
(10 / 9 / 2008)\end{array}$ & $\begin{array}{l}546 \text { F.3d } \\
111\end{array}$ & $\begin{array}{l}\text { In determining } \\
\text { whether a child with } \\
\text { disabilities can be } \\
\text { educated satisfactorily } \\
\text { in a regular class with } \\
\text { supplemental aids and } \\
\text { services a federal } \\
\text { district court should } \\
\text { consider several } \\
\text { factors, including: (a) } \\
\text { Whether the school } \\
\text { district has made } \\
\text { reasonable efforts to } \\
\text { accommodate the child } \\
\text { in a regular classroom; } \\
\text { (b) The educational } \\
\text { benefits available to } \\
\text { the child in a regular } \\
\text { class, as compared to } \\
\text { the benefits provided } \\
\text { in a special education } \\
\text { class; and (c) The } \\
\text { possible negative } \\
\text { effects of the inclusion } \\
\text { of the child on the } \\
\text { education of the other } \\
\text { students in the class. }\end{array}$ & $\begin{array}{l}\text { A student with Down } \\
\text { syndrome, hearing } \\
\text { impairment, and } \\
\text { significant health } \\
\text { problems was placed } \\
\text { in the regular } \\
\text { classroom for } 60 \% \text { of } \\
\text { the day. The district } \\
\text { hired hearing and } \\
\text { behavioral } \\
\text { consultants to work } \\
\text { on the student's } \\
\text { programming. } \\
\text { Parents wanted at } \\
\text { least } 80 \% \text { of the } \\
\text { student's day in the } \\
\text { regular classroom. }\end{array}$ & $\begin{array}{l}\text { While including stu- } \\
\text { dents in the regular } \\
\text { classroom as much } \\
\text { as is practicable is } \\
\text { undoubtedly a central } \\
\text { goal of the IDEA, } \\
\text { schools must attempt } \\
\text { to achieve that goal } \\
\text { in light of the equally } \\
\text { important objective } \\
\text { of providing an edu- } \\
\text { cation appropriately } \\
\text { tailored to each } \\
\text { student's particular } \\
\text { needs. The court } \\
\text { determines that the } \\
\text { school district was } \\
\text { justified in removing } \\
\text { the child from the } \\
\text { regular classroom } \\
\text { and providing educa- } \\
\text { tion in a segregated, } \\
\text { special education } \\
\text { class. }\end{array}$ \\
\hline $\begin{array}{l}\text { B.S. v. } \\
\text { Placentia- } \\
\text { Yorba Linda } \\
\text { Unified School } \\
\text { District } \\
(1 / 5 / 2009)\end{array}$ & $\begin{array}{l}306 \text { Fed. } \\
\text { Appx. } 397\end{array}$ & $\begin{array}{l}\text { Mainstreaming is a } \\
\text { policy which must be } \\
\text { balanced with the } \\
\text { primary objective of } \\
\text { providing handicapped } \\
\text { children with an } \\
\text { "appropriate" } \\
\text { education. }\end{array}$ & $\begin{array}{l}\text { Parents of a child } \\
\text { with ASD alleged } \\
\text { violation of the LRE } \\
\text { mandate because of } \\
\text { placement in a 90- } \\
\text { minute separate class. } \\
\text { They requested } \\
\text { placement in a } \\
\text { separate } 240 \text {-minutes } \\
\text { class as an } \\
\text { alternative. }\end{array}$ & $\begin{array}{l}\text { The U.S. Court of } \\
\text { Appeals for the } \\
\text { Ninth Circuit has } \\
\text { adopted a four-factor } \\
\text { balancing test to } \\
\text { determine whether a } \\
\text { district's placement } \\
\text { offers education in } \\
\text { the LRE: (a) The } \\
\text { educational benefits } \\
\text { of placement full- } \\
\text { time in a regular } \\
\text { class; (b) The non- } \\
\text { academic benefits of } \\
\text { such placement; (c) } \\
\text { The effect the } \\
\text { student has on the } \\
\text { teacher and other } \\
\text { students in the } \\
\text { regular class; and (d) } \\
\text { The cost of } \\
\text { mainstreaming the } \\
\text { student. } \\
\text { Table } 1 \text { (continued) }\end{array}$ \\
\hline
\end{tabular}




\begin{tabular}{|c|c|c|c|c|}
\hline Name & Citation & Rule of Law & Material Facts & Decision \\
\hline $\begin{array}{l}\text { Richard Paul } \\
\text { E. and Annette } \\
\text { S. B. v. } \\
\text { Plainfield } \\
\text { Community } \\
\text { Consolidated } \\
\text { School District } \\
202(4 / 9 / 2009)\end{array}$ & $\begin{array}{l}2009 \text { U.S. } \\
\text { Dist. } \\
\text { LEXIS } \\
29833\end{array}$ & $\begin{array}{l}\text { The amount of educa- } \\
\text { tional advancement } \\
\text { required for each child } \\
\text { will vary. The Seventh } \\
\text { Circuit has suggested } \\
\text { that the necessary } \\
\text { amount of progress } \\
\text { needed to satisfy this } \\
\text { standard will correlate, } \\
\text { at least to some } \\
\text { degree, with "the } \\
\text { student's abilities," } \\
\text { which reflect the } \\
\text { severity of the child's } \\
\text { disability. }\end{array}$ & $\begin{array}{l}\text { A student with } \\
\text { learning disabilities, } \\
\text { Central Auditory } \\
\text { Processing Disorder, } \\
\text { ADHD, and } \\
\text { Asperger's syndrome } \\
\text { had attended Easter } \\
\text { Seals. After signifi- } \\
\text { cant improvements, } \\
\text { he was placed in } \\
\text { public school. The } \\
\text { guardian objected to } \\
\text { the return and } \\
\text { requested return to } \\
\text { private placement. }\end{array}$ & $\begin{array}{l}\text { Paulie's placement in } \\
\text { the public school } \\
\text { program allowed for } \\
\text { interaction with } \\
\text { nondisabled peers } \\
\text { and provided for all } \\
\text { of his educational } \\
\text { needs. Public school } \\
\text { was the appropriate } \\
\text { placement. }\end{array}$ \\
\hline $\begin{array}{l}\text { James and Lee } \\
\text { Anne D. v. } \\
\text { Board of } \\
\text { Education of } \\
\text { Aptakisic-Tripp } \\
\text { Community } \\
\text { Consolidate } \\
\text { School District } \\
\text { (7/22/2009) }\end{array}$ & $\begin{array}{l}642 \mathrm{~F}, \\
\text { Supp. } 2 d \\
804\end{array}$ & $\begin{array}{l}\text { A school district is not } \\
\text { required to offer } \\
\text { parents a variety of } \\
\text { placement options for } \\
\text { their children and } \\
\text { allow them to choose. } \\
\text { The issue is whether a } \\
\text { chosen placement is } \\
\text { appropriate, not } \\
\text { whether another place- } \\
\text { ment would also be } \\
\text { appropriate, or even } \\
\text { better for that matter. } \\
\text { The LRE requirement } \\
\text { was not developed to } \\
\text { promote integration at } \\
\text { the expense of other } \\
\text { IDEA requirements } \\
\text { and does not apply } \\
\text { unless the education is } \\
\text { appropriate. Under the } \\
\text { unilateral placement } \\
\text { standard, plaintiffs } \\
\text { first must meet their } \\
\text { burden of showing that } \\
\text { the school district's } \\
\text { proposed IEP was } \\
\text { inappropriate. }\end{array}$ & $\begin{array}{l}\text { A student with severe } \\
\text { dyslexia had attended } \\
\text { public school. Parents } \\
\text { argued that the place- } \\
\text { ment was inappropri- } \\
\text { ate withdrew their } \\
\text { daughter, and } \\
\text { enrolled her in } \\
\text { private school. They } \\
\text { sought reimburse- } \\
\text { ment for the } \\
\text { placement. }\end{array}$ & $\begin{array}{l}\text { The district } \\
\text { concluded that a } \\
\text { placement in district } \\
\text { was appropriate, } \\
\text { consequently, a } \\
\text { private placement } \\
\text { would not be the } \\
\text { LRE. }\end{array}$ \\
\hline
\end{tabular}

National and state data. Both state and federal data are collected on the numbers of students served under the IDEA and the settings in which those students are served. The Illinois State Board of Education releases an Annual State Report on Special 
Education Performance which details the environments in which students of different disabilities and ethnic groups receive special education services. The most recent of these to be released reported on the school year ending in 2008. The most recent federal publication, $28^{\text {th }}$ Annual Report to Congress on the Implementation of the Individuals with Disabilities Education Act, 2006 (2009), tracked similar trends nationally. The data included in these two reports will form a backdrop for this discussion.

In 2008 , Illinois served only $49.2 \%$ of students with disabilities in the regular education classroom for $80 \%$ or more of their school days. Nationally, $57.5 \%$ of students with disabilities were educated at this level (Illinois State Board of Education, 2008; U.S. Department of Education, 2009). In Illinois, $26.3 \%$ of students receiving special education services were inside the general classroom $40-79 \%$ of the school day; nationally the percentage was $22.7 \%$. For students with disabilities, $18.4 \%$ were educated inside the general education classroom less than $40 \%$ of the time, while nationally the number was $15.6 \%$. Last, in $2007,6.2 \%$ of students with disabilities in Illinois and $4.2 \%$ nationally were educated in separate educational facilities. While these percentages, on both the state and national levels, do follow the recommendation set forth by Deno's (1970) cascade, Illinois continues to educate children with disabilities in more restrictive settings than the national average.

Speech and language impairments. For students in different disability categories, the percentages of the population served in less or more restrictive environments differ greatly. Students who are identified for special education services for speech and language impairments are educated in the general education setting more than any other disability group. In Illinois, $93.1 \%$ of these students were educated in the general educa- 
tion classroom for $80 \%$ or more of their school days during the 2007-2008 school year; nationally the percentage was 89.1. Students with speech and language impairments were least likely to be educated in separate facilities; the percentages were 0.2 in Illinois and 0.4 nationally. A model like Deno's (1970) cascade does not accurately describe the services provided to students in this disability category since virtually all of these students would fall into the top layer of the triangle.

Learning disabilities. Students with learning disabilities (LD) were educated $80 \%$ or more in the general education classroom at a rate of $47.0 \%$ in Illinois and $59.5 \%$ nationally (Illinois State Board of Education, 2008; U.S. Department of Education, 2009). This group was educated in separate facilities at a rate of $1.0 \%$ in Illinois and $1.3 \%$ nationally. The settings in which this population received services mirror's that described in Deno's (1970) cascade. The concept of least restrictive environment (LRE) for students with LD has been contentious since the advent of special education. Kokoszka and Drye (1981) discussed the needs of these students as they reach high school age. At an age during which students needed the most socialization, they were receiving the least, dependent on self-contained classes and vocational education programs. The authors stated that the role and goal of special education teachers should be to integrate them more fully into the general education environment.

The Council for Exceptional Children (1995) published an informational brochure on inclusive education and students with LD. Recommendations included the use of accommodations and modifications to maximize the time that students were educated in the general education classroom, maintaining a continuum of placements, and encouraging placement decisions that are based on maximizing peer interactions and 
individualized services. The issue of peer interactions has been a recurring theme in research on the inclusive education of children with disabilities, and the research has been conflicting. Researchers have hypothesized that long-term inclusive education improves group interactions but does not substantially affect social standing among peers for students with LD (Estell, Jones, Pearl, Van Acker, Farmer, \& Rodkin, 2008). The peer ratings in this study remained stable over the 3 years of research and echoed findings of previous research (Frederickson \& Furnham, 2004; Salend \& Duhaney, 1999).

A number of studies have focused on making the inclusive education of students with LD more effective and offered suggestions on how to do so. Responsible inclusive education should include consideration of the student and family, professional development, involvement of teachers who choose to participate in inclusive education, sufficient resources for inclusive classrooms, maintenance of a continuum of services, and a service delivery model that was established and evaluated school wide (Vaughn \& Schumm, 1995). Vaughn and Schumm warned that "irresponsible inclusion will yield a deterioration in educational practices involving individuals with disabilities" (p. 269). Zigmond and Baker (1995) reinforced that "special education in inclusive programs is, by design, no longer special"' (p. 245).

In spite of the difficulty instituting effective inclusive education, the related research has shown a general consensus that students with LD should spend the majority of their school days in general education classrooms (Klingner, Vaughn, Hughes, Schumm, \& Elbaum, 1998; Marston, 1997; McLeskey, Hoppey, Williamson, \& Rentz, 2004). In spite of this consensus, the aforementioned data for students with LD in Illinois and nationally illustrate that this continues not to be the case. During the 1980s, school 
districts across the nation educated students in increasingly restrictive settings (McLeskey \& Pacchiano, 1994). Even during the inclusive education movement of the 1990s, few states moved toward LREs, and those that did moved back toward more restrictive placements as the decade came to a close (McLeskey et al., 2004). The recommendations of the mid-1990s, not yet evident in schools implementing inclusive educational practices, have continued to be made in recent research. Dukes and Lamar-Dukes (2009) posited the idea that inclusive educational practices in secondary schools must be designed to define needs of students, purposes and functions of the educational system, personnel training needed, and evaluation of the system.

Other health impairments. Rates for students with other health impairments (OHI) indicate that $54.9 \%$ of them were educated $80 \%$ or more in general education classrooms in Illinois, while the rate was 59.5\% nationally (Illinois State Board of Education, 2008; U.S. Department of Education, 2009). This population was educated in separate educational facilities at a rate of $4.1 \%$ in Illinois and $3.1 \%$ nationally. As for students with LD, Deno's cascade was reflected in the distribution of these students with OHI across educational environments. Students with Attention Deficit Hyperactivity Disorder (ADHD) were included in the OHI category, and they may have been the most difficult to include and educate effectively in the general education classroom (Humphrey, 2009; Sava, 2000). Sava provided a menu of options for structuring the environment of students with ADHD that included behavioral contracts, group contingencies, token economies, and classroom organization among others. Humphrey noted that in order to educate students with ADHD in the regular classroom, teachers need to have a better understanding of the role of medication, provide structure, minimize 
distractions, and use both cognitive and behavioral strategies to help students be successful. It may be the lack of training of general education teachers in these areas that contributes to the exclusion of this group of students.

Autism spectrum disorder. In Illinois, only $29.8 \%$ of students with autism spectrum disorders (ASD) were educated in the general education classroom $80 \%$ or more, while $34.8 \%$ of them were nationally during the 2007-2008 school year (Illinois State Board of Education, 2008; U.S. Department of Education, 2009). In Illinois, 15.0\% of students with ASD were educated in separate facilities while $9.6 \%$ of the population was nationally. Placements for this group did not follow the model of Deno's (1970) cascade as the percentages of students both nationally and in Illinois were higher for those placed in separate educational facilities or general education for less than $40 \%$ of the day than in less restrictive settings. It may be that participation in classrooms with nondisabled peers is more essential to this group than to any other group of students with disabilities because of their deficits in communication and social skills (Leach \& Duffy, 2009).

Peer modeling or peer tutoring have been suggested as interventions that may allow students with ASD to spend more of their time in the general education classroom while improving their social skills (Campbell, Ferguson, Herzinger, Jackson, \& Marino, 2005; Koenig, Bleiweiss, Brennan, Cohen, \& Siegel, 2009). In addition, Robertson, Chamberlain, and Kasari (2003) found that relationships between children with ASD and their nondisabled peers were affected positively by positive relationships with their teachers. Regardless of the presence of a paraprofessional or the method of teaching in the classroom, students with ASD fared better when their teachers reported positive 
feelings about them. New York City's ASD Program uses small class size, a co-teaching model, a daily class schedule, visual aids, teacher training and ongoing site support, and choice-making opportunities to create a therapeutic environment for students with ASD in general education classrooms (Koenig et al., 2009).

Intellectual disabilities. Students with intellectual disabilities (ID) spent the least amount of time in the general education classroom with $5.4 \%$ of them spending $80 \%$ or more of the day in the general education classroom in Illinois. The percentage was 15.9\% for this group nationally (Illinois State Board of Education, 2008; U.S. Department of Education, 2009). This population was educated in separate educational facilities at a rate of $14.9 \%$ in Illinois and $7.3 \%$ nationally. To a greater extent than students with ASD, students with ID were educated in more restrictive settings at much higher rates than students with disabilities in general. The triangle that illustrated Deno's (1970) cascade in no way depicted the placements of students with ID.

Parent and teacher concerns may have contributed to the statistics for these students. Johnson (2006) noted that parents and teachers were concerned about resources and relevance of the curriculum; however, both groups responded positively to the social benefits of inclusive education for students with Down syndrome. Parents who participated in Johnson's study noted the following benefits of inclusive education for their children: positive peer role models for speech and behavior, academic gains, high expectations, fostered independence, and the opportunity for non-disabled children to learn about people with disabilities. Negative feedback in the same study included the limited resources for inclusive education, insufficient knowledge and skills of some staff members, expectations that were too high, and the fact that peers matured at a faster rate 
than the students with disabilities. In spite of concerns, the majority of parents interviewed as part of the study stated that they would have chosen the mainstream placement again if given the opportunity.

Even with concerns and drawbacks, the recommendation continued to be that students with ID be included in the general education classroom because of the opportunities to interact socially and with the curriculum (Smith, 2006). One strategy suggested for improving the inclusion of students with ID in general education classrooms was selfregulation, which improved classroom performance (Wehmeyer, Yeager, Bolding, Agran, \& Hughes, 2003). Johnson (2006) cited "the positive ethos of the schools" as being essential for successful inclusive environments (p. 28) and Smith (2006) added that "the importance of school context cannot be overstated" (p. 336). These authors agreed that although curriculum and instruction are important for successful inclusion of students with CD, the role of the inclusive school culture is paramount.

Emotional disabilities. Last, students with ED were educated $80 \%$ or more in the general education classroom at a rate of $25.5 \%$ in Illinois and $37.5 \%$ nationally during the 2007-2008 school year (Illinois State Board of Education, 2008). More sobering for this group was the number of students educated in separate educational facilities: $30.4 \%$ of students in Illinois and $20.1 \%$ of students nationally were removed completely from general education settings and placed in separate educational facilities. This was much higher than for any of the aforementioned groups, and the placement of these students in no way reflected the model set forth in Deno's (1970) cascade. Heath, Petrakos, Finn, Karagiannakis, McLean-Heywood, and Rousseau (2004) compared students with ED in general education and separate settings. The students in general education participated in 
a team-model school and were included in regular classes. Findings indicated that externalizing behaviors decreased for students in inclusive education settings; however, these children exhibited more internalizing symptoms and off-task behaviors throughout the year compared to those in segregated settings.

When studying the self-determination of students with ED across settings, Gelder et al. (2008) found that students in residential settings rated themselves higher in selfdetermination than students with ED from either public school or separate facility settings. However, parents and teachers rated the students in the public high school the highest in self-determination. In a study of 26 students with ED who had received special education services in a residential school, the majority indicated that the experience had been positive and that the residential setting was the only educational placement where they had felt supported (Farrell \& Polat, 2003). While residential placements should not be the first placement considered for students with ED, the extreme needs of these students and the benefits they reaped clearly warranted the placements. In addition, Farrell and Polat asserted that residential settings offered the evening and weekend support, never provided by general education, required by some students with ED. The aforementioned teaming model (Heath et al., 2004) was recommended to improve the behavior of students with ED in general education settings. Kauffman and Lloyd (1995) proposed the following list of interventions as those common to successful inclusive education programs for students with ED: multi-component treatment matched to the needs of individual students, systematic and data-based interventions with ongoing progress monitoring, system-wide dedication to continued programming, and regular practice of academic and social skills with an emphasis on generalization. Another 
recommendation was the use of Positive Behavior Support (PBS). PBS (Hendley, 2007) stresses the importance of identifying maladaptive behaviors, understanding their function, and designing positive interventions to decrease those behaviors. Interventions that help students with ED include school-wide environmental changes, social skills instruction, and problem-solving instruction.

School-wide systems, particularly effective administration, a staff dedicated to inclusive education, and access to outside agencies have been cited as essential for the successful inclusion of students with ED (Visser, Cole, \& Daniels, 2002); however, these authors recognized that for some students with ED, time out of general education is necessary for them to make educational progress. Because many general education teachers feel unprepared to teach students with ED and in order for school staffs to be effective in their attempts to implement more inclusive programs, training and ongoing support are needed (Shapiro, Miller, Sawka, Gardill, \& Handler, 1999). Home-school connections, ongoing behavior assessment, academic interventions, and environmental structure are also seen as important supports for students with ED who are moving into inclusive educational settings (MacLeod, 2001).

\section{Mainstreaming, REI, and Inclusive Education Movements and LRE}

Reynolds (1989) described the history of LRE and special education placements as "progressive inclusion" (p. 7). Mainstreaming was initially the way to integrate the normalization principle (Wolfensberger, 1972) into education by placing students with disabilities in regular classrooms (MacMillan, 1977). Conversely, Vergason and Anderegg (1992) argued that normalization was more closely related to LRE and the continuum of placements than mainstreaming because of its focus on adaptive behaviors. 
According to MacMillan (1977), mainstreaming needed to include placement in general education classrooms, shared responsibility among general and special education teachers for students, and an elimination of the intellectual disability label (p. 449). However, MacMillan did question whether or not general education settings were prepared for children with intellectual disabilities.

During the 1980s, proponents of the REI asserted that special education, which included expensive and burdensome systems of evaluation, labeling, and placement into special classes, was not working and served to segregate students with disabilities (McLeskey, Skiba, \&Wilcox, 1990; Reynolds, 1988). Reynolds noted that "the REI proposes that we need to formulate and test procedures by which special education teachers and their resources can be joined with regular teachers to help meet individual differences in the classroom" (p. 354). Other arguments supporting the REI were that quality teachers could teach any students, who were mostly alike, and that those students had been set apart primarily by their disability labels (Kavale \& Forness, 2000). In addition, the REI recognized that the poor performance of students with disabilities was the result of the environments in which those students were educated, not because of the students themselves; therefore, changing the general education environment would produce better student outcomes (Ysseldyke, Algozzine, \& Thurlow, 1992).

The REI had several goals. These were to merge the general and special education systems, to increase greatly the number of students with disabilities in general education classrooms, and to improve the academic achievement of students at-risk and those with disabilities (Fuchs \& Fuchs, 1994). Advocates also hoped that in moving students into general education classrooms, the students in more restrictive placements 
would move out of those placements into environments that more closely approximated regular classrooms. They desired to make the LRE less restrictive for all students along the continuum. While most proponents did not advocate for the end of special education, they hoped that the successes of special education would be shared with general education and that the strategies and techniques of special education would "bubble up" into regular classrooms (McLeskey et al., 1990, p. 320).

In spite of the promise that the REI held for some students, the movement had its detractors who argued that special education could be improved rather than eliminated. Kauffman and Hallahan (1990) pointed out that there was no one answer to the placement question, that teacher education must remain specialized in order for special education to exist, and that the answer to the problems of special education was to become more effective across settings. Kauffman (1989) made a number of other arguments against the REI, noting that, "the most important equity issue is the quality of instruction, not the place of instruction (p. 258). In addition, Kauffman pointed out that students with disabilities had already been unsuccessful in general education, the setting recommended by proponents of the initiative. The REI also lacked a sound research base (Kavale \& Forness, 2000).

Fuchs and Fuchs (1994) categorized the REI as a movement that advocated primarily for the needs of students with high-incidence disabilities. Elements of this movement became part of the inclusive education movement; however, inclusive education was driven principally by advocates of children with low-incidence disabilities. Proponents of "full inclusion" called for the demise of the continuum of services and emphasized the importance of the social benefits to be had by students with disabilities in 
general education classrooms (Fuchs \& Fuchs). Their position was essentially that there was no need for a continuum because the regular classroom was the LRE, and they believed that general education would rise to the challenge of educating all students (Fuchs \& Fuchs; Kavale \& Forness, 2000; Zigmond, Kloo, \& Volonino, 2009). The argument that all students with disabilities should be educated in general education classrooms was primarily a moral one, essentially that it was simply the fair, equitable, and right thing to do, and the argument frequently cast those who disagreed as uncaring (Kavale \& Forness; Shanker, 1994/1995; Stainbeck \& Stainbeck, 1992; Wright, 1999). Arguments for inclusive education have strengthened during the last decade with the mandates that students with disabilities must participate in the same accountability systems and be held to the same standards as their general education peers (Zigmond et al.).

Inclusive education also had its opponents, many of whom levied the same arguments as those that had been made against the REI. Among the arguments against inclusive education were that it was not supported by empirical evidence, that general education was not equipped or willing to accept all students with disabilities, and that inclusive education would take a great deal of preparation (Kavale \& Forness, 2000; Kavale \& Mostert, 2003). Others questioned whether or not inclusive education actually eliminated special education: "If a differentiated education is provided in the same place as everyone else, on the same content as everyone else, with adapted instruction that is not unique to the student with disabilities, is the student receiving a special education?" (Zigmond et al., 2009, p. 201). 


\section{Legal Basis for LRE}

\section{Historical Legislation}

The Education for All Handicapped Children Act of 1975 (P.L. 94-142) required that all school districts receiving federal funds must provide a free appropriate public education (FAPE) to students with disabilities. The law defined "handicapped child" and set forth the basic tenets of special education that have remained constant in today's public schools. These requirements were the guarantee of a FAPE for students with disabilities, the provision of special education and related services designed to meet the individual needs of the student, an IEP for each eligible student, nondiscriminatory and multi-disciplinary assessment, education in LRE, and the rights of parents to participate in and consent to all decision making and evaluation. In addition, due process procedures guaranteed parents the right to challenge actions taken by the school. While federal statutory law is the primary source of guidance in special education, due process has been used and court cases have been filed when there has been confusion or disagreement about the language and meaning of laws. These cases have helped to clarify and define terms in the law. Table 1 contains a list of cases that have alleged violations of special education legislation. The first two cases, Rowley and Honig, alleged violations of P.L. 94-142. These cases helped to clarify the meaning of FAPE and LRE. Since its initial passage, P.L. 94-142 has been reauthorized a number of times, sometimes more substantially than others. The next sections of this chapter include more detailed discussion of those revisions.

Rowley and Honig merit further discussion as the decisions in these federal cases have affected subsequent legislation and practice. The Supreme Court in Board of 
Education of the Hendrick Hudson Central School District Westchester County, et al. v. Rowley (1982) held that the lower courts erred when they determined that P.L. 94-142 required states to maximize the potential of each child with a disability commensurate with the opportunity provided those without disabilities. Amy Rowley was a deaf student who was placed in regular kindergarten and first grade classes. While her parents argued that she required the services of an interpreter, the school district maintained that an appropriate education could be provided without one. Rowley established the "basic floor of opportunity" that schools are required to provide as one consisting of access to instruction, individualized and specialized, and indicated that FAPE must enable children with disabilities to benefit from instruction. The decision required that states establish procedures ensuring that, "special classes, separate schooling, or other removal of handicapped children from the regular educational environment occurs only when the nature or severity of the handicap is such that education in regular classes with the use of supplementary aides and services cannot be achieved satisfactorily." The Rowley case established that equal protection required equal access for students with disabilities.

In Honig v. Doe (1988), the Court held that the intent of P.L. 94-142 related to exclusions of students with disabilities from school was to prevent schools from indefinitely excluding students with disabilities from school. Students with emotional disturbance were suspended indefinitely, pending expulsion, for disruptive and violent behavior that was related to their disabilities. In Honig, the Court stated that suspensions in excess of 10 days constituted a change of placement, and that the "stay put" provision of P.L. 94-142 mandated that the child remain in the current educational placement 
unless the school and parents agreed to a change of placement. The Court also declined to read a "dangerousness" exception into the "stay put" provision.

The revision of P.L. 94-142 in 1990 renamed the statute the Individuals with Disabilities Education Act (IDEA). Another important language change was the replacement, throughout the law, of handicapped child with child with a disability. This reauthorization of the law emphasized defining the LRE as a requirement that the child with a disability, to the maximum extent appropriate, be educated with children without disabilities: defined as the child with a disability being educated in the same classroom as he or she would be if he or she did not have a disability. Like P.L. 94-142, the IDEA was clarified through a number of court cases. Table 1 contains court decisions that have shaped the reauthorizations of IDEA and the way that the law has been implemented. With the exception of Rowley and Honig, all cases described in Table 1 have alleged that school districts violated the IDEA.

The amendments set forth in the IDEA 1997 expanded access of students with disabilities to the general education curriculum and settings in a number of ways. Congress noted that the IDEA had been successful in ensuring access to education for students with disabilities; the law must go further and improve students' performance and achievement. For the first time, the focus of the law moved from access to achievement. To further this aim, students' IEPs were to include not only measurable goals, but the means by which those goals would be measured. Students with disabilities were to have access to the general curriculum and be included in state and district assessments, ensuring that they were held to the same expectations as were students without disabilities. In addition, if a student was removed from the general education 
environment, his or her IEP was to contain a statement explaining why that removal was necessary.

At least one general education teacher was to be part of the IEP team, and eligibility was again expanded to allow children with ADHD to be considered in the OHI category. Discipline underwent many changes. Schools were required to provide services to a student who was removed from school for more than 10 school days in a school year; in addition, the IEP team needed to develop a functional behavioral assessment if one was needed or review the existing behavior intervention plan. Under these amendments, schools could unilaterally remove a student for up to 45 days if the student's discipline was for weapons or drugs offenses. In this reauthorization, LRE was defined as an assurance that all students would have "access to the general curriculum."

\section{Recent Legislation}

Congress began to fund K-12 education at significant levels in 1965 through the Elementary and Secondary Education Act (ESEA). After several renewals, in 2002, the ESEA was reauthorized as the No Child Left Behind (NCLB) Act. This Act was based on the theory of standards-based reform and represented a substantial change in the accountability that public schools in the United States would have to the federal government. The purpose of the law was "to ensure that all children have a fair, equal, and significant opportunity to obtain a high-quality education and reach, at a minimum, proficiency on challenging State academic achievement standards and state academic assessments" (NCLB Act, Title 1, Sect 1001.). The purpose was more specific in that it specifically addressed the educational needs of low-achieving children, those who attended high poverty schools, were migratory, had limited English proficiency, had 
disabilities, and were neglected or delinquent. Title I of the NCLB Act provides the bulk of federal K-12 funding in order to support schools, and the support is provided to schools that educate children who are economically disadvantaged. This section of the law outlines some of the requirements that schools must meet in order to receive federal funding.

The Four Pillars of the NCLB Act are (a) stronger accountability for results, (b) more freedom for states and communities to use resources where they are most needed, (c) more choices for parents, and (d) proven education methods. State and local education agencies must employ "highly qualified" teachers, give assessments in basic skills to students in certain grades, set state learning standards, utilize "scientifically-based research," provide high quality reading programs, make adequate yearly progress (AYP) toward meeting state learning standards, and ensure that all students meet state learning standards in math and reading by 2014. In addition to monitoring the progress of schools, districts, and the state, the NCLB Act requires the disaggregation of data in order to measure the progress of specifically designated subgroups. Students with IEPs are one of these groups. Some of the specific achievement goals of the NCLB Act are that all students will reach high standards, achieve proficiency on state assessments by the 2014 school year, and graduate from high school. These goals are of particular interest to the field of special education as students with disabilities are frequently not academically proficient and are more likely than their nondisabled peers to drop out of school.

Title IV of the NCLB Act includes the Safe and Drug-Free Schools and Communities Act (SDFSCA) and the Gun-Free Schools Act (GFSA). This Title of the NCLB Act were included in order to support schools in establishing programming that 
prevents violence and the use of alcohol, tobacco, and drugs in schools; to promote parent and community involvement; and to advance safe school environments that encourage student achievement. In addition to supporting programming, the GFSA required that states receiving federal funds expel a student who brings a gun to school. The expulsion must be for a period of at least 1 year. Moreover, school districts must also refer to the criminal justice system students bringing firearms or weapons to school.

The NCLB Act is important to students with disabilities because of their inclusion in the accountability and discipline systems. Students with disabilities must be assessed as part of the AYP system; if this system, even with appropriate accommodations, is not appropriate for a student's needs, the student must be assessed using an alternate assessment. IEP teams will determine which accommodations are needed by individual students with disabilities; however, states disallow accommodations that may threaten the validity of the tests. For example, Illinois does not allow any reading of tests to students on the reading portion of the assessment, even if that is an accommodation to which the student is entitled through his or her IEP. The scores of students with disabilities must be reported as a subgroup and as part of the general school population. The NCLB Act placed a cap on the number of students who may be assessed using alternate methods; that cap is $1 \%$ of the school population involved in testing. In Illinois, schools may be able in certain circumstances to count $2 \%$ of the testing population who are assessed using alternate methods.

The most recent reauthorization of the IDEA was passed in 2004. The purpose of the IDEA was to "ensure that all children with disabilities have available to them a free appropriate public education that emphasizes special education and related services 
designed to meet their unique needs and prepare them for further education, employment, and independent living." Again, the emphasis of the law changed: from access and progress to results. Efforts were made during this reauthorization to align the IDEA with the NCLB Act. The laws agreed that students should be included in state-wide assessments but that IEP teams should determine how, not if, the students should be assessed. The IDEA now allows state funds to be used to design appropriate accommodations and assessments for students with disabilities, requires goals that align with the AYP requirements for students with disabilities, mandates "highly qualified" teachers, and obligates accountability through reporting to the state and public.

\section{Statement of the Problem}

The IDEA mandates that students with disabilities be provided FAPE in the LRE. This has been defined through legislation and case law as a removal from the general education environment only when the students' educational needs cannot be met in that environment. However, the IDEA allows schools to place students unilaterally for up to 45 days. The NCLB Act mandates that schools expel students, even those with disabilities, for certain offenses. While students with disabilities continue to receive services during the period of their expulsion, those services may not be in the LRE according to the IDEA. Although the NCLB Act has helped students with disabilities become more integral members of the school society in a number of ways, the IDEA and the NCLB Act are at odds in regards to discipline. The NCLB Act clearly states that students with disabilities can be unilaterally placed in an alternative setting for more than 45 days.

When students with disabilities are expelled, they may be placed outside their home schools. In Illinois, students may be expelled to Regional Safe School Programs (RSSPs) which are intended to educate students who have been suspended multiple times 
or expelled. These placements may not have been made by IEP teams for educational reasons; the purpose of the placements may have been to maintain order at the students' home schools.

I designed this study to explore the perspectives of students with disabilities who had been suspended multiple times or expelled and subsequently placed at one RSSP. The positive behavior management, academic engagement, and caring teachers at alternative schools have been named as reasons why at-risk students find success there (Quinn, Poirier, Faller, Gable, \& Tonelson, 2006). My interviews with students, during the current study and a pervious study (deGruy, 2009) revealed much about the levels of support and services they perceived that they received at their home schools and the therapeutic school or RSSP.

\section{Significance of the Study}

While much research exists about the many manifestations of alternative schools, little research focuses specifically on students with disabilities in alternative schools or the perspectives of students enrolled in alternative schools. My review of the literature revealed no research that described the perspectives of students with disabilities attending alternative schools in which they had been placed involuntarily. Chapter II contains a review of related literature on alternative schools; the focus is on students with disabilities who attend these schools. The primary purpose of this study was to give a voice to these marginalized students who were excluded from their home schools.

Students with disabilities who are unilaterally removed from their home schools have unique perspectives on their schooling. All students included in this study attended the RSSP for disciplinary reasons: three had been expelled, two had been placed after 
multiple suspensions, and two had been given the choice to attend after multiple suspensions. Their perspectives are important both for the home schools and RSSP. The information gleaned from these students' interviews may inform effective programming for students with disabilities in both educational settings.

\section{Purposes of the Study}

The primary purpose of this study was to investigate the perspectives of students with IEPs who attend a regional safe school on their educational experiences. The study focused on the perspectives of students who attended a regional safe school located in a small urban community but serving a number of surrounding districts. By exploring students' perspectives, this study yielded information on how schools might better support students with disabilities in both their home and alternative schools. Specifically, the purposes of this study were the following:

1. To identify the perspectives of students with disabilities related to their educational experiences.

2. To identify the specific elements of educational placements that contribute to the success or failure of students with disabilities.

3. To identify whether the least restrictive environment was the most desirable to the student and to what extent that setting facilitated student success.

\section{Research Questions}

The research questions that guided the current study were the following:

1. What are the perspectives of students enrolled in a regional safe school regarding their comparative experiences in their home schools and regional safe school?

2. What are the perspectives of students enrolled in a regional safe school regarding strengths and weaknesses of the services and programming received at their home schools and regional safe school? 
3. What are the perspectives of students regarding the effectiveness of their schooling in their home schools and regional safe schools setting?

4. What do students identify as the key elements to their success in school, and what are their perspectives on how both settings address those elements?

\section{Definitions of Terms}

Student with a disability: For the purpose of this study, student with a disability is defined as a student who qualifies for special education services in one of the disability categories defined by the IDEA.

Alternative education school: The U.S. Department of Education (2002) defines an alternative education school as:

A public elementary/secondary school that: (1) addresses needs of students that typically cannot be met in a regular school, (2) provides nontraditional education, (3) serves as an adjunct to a regular school, or (4) falls outside of the categories of regular, special education, or vocational education. (pp. 55-56)

Alternative placement: For the purpose of this study, an alternative placement is any school, outside of his or her home public school, that a student with a disability might attend.

Least Restrictive Environment (LRE): As defined by the IDEA, "to the maximum extent appropriate, children with disabilities...should be educated with children who are not disabled, and...special classes, separate schooling, or other removal of children with disabilities from the regular educational environment should occur only when the nature or severity of the disability is such that education in regular classes with the use of supplementary aids and services cannot be achieved satisfactorily" (20 U.S.C. 1412(a)(5)(B)).

Intellectual disability: "Intellectual disability" is the term which will replace the language "mental retardation" in all federal legislation. The labels cognitive disability, 
cognitive impairment, and mental impairment have also been used to name this disability category.

\begin{abstract}
Assumptions
I assume that this study's participants were honest in sharing their experiences and perspectives during the interviews. In order to assure equal opportunity for student participation, I used a semi-structured interview protocol and recorded and transcribed all interviews. Following transcription and data analysis, I completed member checking to determine that interviews reflected the accurate perspectives of the participants.
\end{abstract}

\title{
Delimitations
}

Eight students who met eligibility criteria for this study participated in this study. I selected the participants according to the following guidelines: attendance at a regional safe school, identification as a student with a disability who received special education services, enrollment in grades 6 through 12, and placement at the regional safe school because of disciplinary reasons.

\section{Limitations}

Because I derived transcripts of the interviews from audio recordings, intelligibility could have affected the reliability of interview data. However, qualified individuals completed all transcriptions. Since I, the primary researcher, have worked with students who have been placed at regional safe schools, members of my dissertation committee monitored my personal bias. 


\section{Chapter Summary}

IEP teams must place students with disabilities in the LRE that will meet the students' needs. Legislation and case law have defined the LRE mandate; however, a continuum of services model, consistent with Deno's (1970) cascade, provides a range of placements in which students with disabilities may be educated. Students with disabilities are educated in a number of settings, but their prevalence in different environments varies by disability category; the acceptance of different environments varies by disability category as well. In spite of the IDEA and the LRE mandate, some students with disabilities are placed unilaterally in settings outside their home schools.

The primary purpose of this study was to explore the perspectives of students who attend RSSPs. It is essential that these students find success at school, and their viewpoints about the factors that contribute to their success cannot be ignored. The data generated by this study will inform programming at RSSPs. In addition, the data are critical for home public schools as they examine ways in which to support students with disabilities who may be at risk for exclusion. 


\section{CHAPTER II}

\section{REVIEW OF RELATED LITERATURE AND RESEARCH}

The purpose of this chapter is to describe the research and existing literature related to alternative schools. Specifically, this chapter contains descriptions of the following topics as they relate to alternative schools: (a) the history and definition of alternative schools, (b) national studies, (c) state legislation, (d) students served, (e) special education and alternative schools, (f) types of schools, (g) student perceptions of schools, and (h) a description of a sample district.

\section{Methods for Conducting the Search for Related Literature}

I conducted a systematic search of related literature using the following databases: Academic Search Complete, FirstSearch, Ovid, and PsycINFO. Because of the lack of a consistent definition for alternative schools, I used the following combinations of terms: special education or students with disabilities were combined with alternative school(s), alternative education school(s), therapeutic school(s), day treatment school(s), charter school(s), and residential school(s). Although the search yielded several articles on alternative schools alone, many did not address students with disabilities; thus the reason for combining terms. I also conducted an Internet search for state legislation related to alternative schools and reviewed the Illinois State Board of Education's website in order to create a profile of the Regional Safe Schools Programs (RSSPs). 


\section{Results of Literature Review}

\section{History and Definition of Alternative Schools}

After the turn of the $20^{\text {th }}$ century, many states passed compulsory attendance laws, which required that all children attend school. Prior to the passage of these laws and the curbing of child labor, the exclusion of certain students was used to maintain order in schools (Tropea, 1987). These were the students who were sometimes classified as "disciplinary" or "backward." In order to continue maintenance of order, special schools and ungraded classrooms were put in place in urban areas to segregate those students who had formerly been excluded. Compulsory education laws, then, did not eliminate exclusion; they merely changed its outward appearance. These special schools, precursors to today's alternative schools, benefitted school districts in a number of ways. They removed "unmanageable pupils" (Tropea, 1987, p. 34) from teachers' classrooms, created a workforce through vocational training and work permits, and allowed schools to appear more efficient since special students were not included in schools' promotion rates.

These continue to be reasons why school districts find it efficient to enroll students in alternative schools. However, as is true of today's alternative schools, the Detroit Annual Report (1911) noted that, "it is not intended that pupils entering the ungraded schools shall stay there indefinitely" (as cited in Tropea, 1987, p. 36).

The U.S. Department of Education (2002) defined an alternative education school as:

A public elementary/secondary school that: (1) addresses needs of students that typically cannot be met in a regular school, (2) provides nontraditional education, (3) serves as an adjunct to a regular school, or (4) falls outside of the categories of regular, special education, or vocational education. (pp. 55-56) 
In spite of this description, the types of alternative schools in operation in the US are many and varied, and a true definition of alternative education may not exist (Bullock, 2007; Katsiyannis \& Williams, 1998; Lehr \& Lange, 2003a; Lehr, Tan, \& Ysseldyke, 2009). Researchers generally agree that alternative schools "tend to serve students who are at risk for school failure within the traditional educational system" (Lehr et al., p. 19). Alternative schools were often designed to help students at risk for drop out or expulsion. However, little research exists exploring whether those outcomes are avoided for a significant number of students or whether positive outcomes are likely (Atkins, Bullis, \& Todis, 2005). In addition, while students often make academic and behavioral improvements in alternative schools, their progress does not continue when they return to their home schools (Brown \& Beckett, 2007).

Alternative schools have educated an increasing number of students over recent years; however, little is known about the programming these students receive (Kleiner, Porch, \& Farris, 2002). Raywid (1994) classified alternative schools into three categories: Type I are schools of choice that emphasize innovative curriculum or instructional practices; Type II are "last chance" schools that save students from expulsion and emphasize behavior modification; Type III are those that take a more therapeutic approach, emphasizing remediation of academic or social emotional skills. The distinction is important because student choice has been identified as an important component in the success of students attending alternative schools; in addition, this classification system has "implications tied to student motivation, outcomes, and overall program effectiveness" (Lehr \& Lange, 2003b, p. 61). Alternative schools may also be categorized into 
groups based on whether their goal is to change the school, change the student, or change the educational system (Quinn, Poirier, Faller, Gable, \& Tonelson, 2006).

\section{National Studies}

National studies have provided statistics on alternative schools and programs for students at risk for educational failure. Kleiner et al. (2002) reported findings of a national survey of district-operated alternative programs and schools for the 2000-01 school year. Updated data were analyzed by Carver, Lewis, and Tice (2010) for the 2007-08 school year. In addition, the later study included data on alternative programs not operated by the district; however, alternative schools or programs that served only students with disabilities were excluded from the study.

During the 2007-08 school year, $40 \%$ of school districts administered their own alternative schools or programs; $64 \%$ had either their own program or used a program operated by another entity (Carver et al., 2010). Public school districts reported that 646,500 students attended alternative schools during the 2007-08 school year and that those students were more likely to be enrolled in high school than middle or elementary schools. Of the 558,300 students attending district-administered alternative schools and programs, 90,300 , or $16 \%$, received special education services. In addition, $28 \%$ of students who were enrolled in alternative schools and programs were placed because of functional behavioral assessments, which may indicate a disability or concerns by public school staff.

The Carver et al. (2010) report contains much information about the number of districts administering alternative schools, why students attend those schools, and the ways in which districts are educating their at-risk students; however, it leaves questions 
about the alternative education of special education students. Readers should be cognizant of the fact that the study excludes information on the numbers of students with disabilities who attend facilities that serve only students with disabilities.

While the research on alternative schools is expanding, information on the services provided to students with disabilities in alternative schools is still lacking (Lehr et al., 2009; Unruh, Bullis, Todis, Waintrup, \& Atkins, 2007). The Alternative Schools Research Project (ASRP, 2005) was initiated to study alternative schools in the US, particularly the ways in which these programs include and serve students with disabilities. The ASRP mission was to be accomplished through four individual studies. Study 1 was designed to provide an understanding of alternative schools nationwide and whether those schools served students with disabilities. Study 2 involved a more in-depth look at the state level and included case studies of five states. Study 3 consisted of visits to alternative schools to collect data from students, parents, and educators. Last, Study 4 provided a synthesis of the previous studies and recommendations (ASRP, 2005). These projects helped to define alternative education and describe its role in the provision of services to students with disabilities; study findings have been incorporated into the following review of state legislation pertaining to alternative schools.

\section{State Legislation}

To determine how alternative schools are conceptualized from state to state, an examination of state-level legislation and policy is necessary. Katsiyannis and Williams (1998) found that 20 states (52.6\% of 38 responding) had defined alternative education through legislation; however, 22 (57.9\%) states had laws governing alternative education. The definitions that states provided contain some common elements including: (a) the 
location was separate from the home school, (b) the curriculum was non-traditional and more flexible according to students' needs, (c) instructional methods were different from those in the traditional school, and (d) student outcomes were defined in a manner that reflected students' at-risk status.

By 2003, the numbers identified by Katsiyannis and Williams (1998) had increased, as reflected in the ASRP's report, which noted that 48 of 50 states (94\%) had legislation that addressed alternative education, and laws of 34 states (71\%) defined alternative schools (Lehr, Lanners, \& Lange, 2003). The most comprehensive legislation is that which addresses alternative schools outside the general school or educational code (Lehr et al., 2009). Many of these definitions included the language found in the legislation in 1998; however, some additional information was included. The idea that alternative schools were designed particularly for students who had not been successful in their traditional schools was included in Arizona. The Iowa definition distinguished between alternative program and alternative school, and delineated that students attended by choice. Only students who had dropped out of high school were included in the Massachusetts definition of alternative education. The common elements in the definitions remained the same in this later study (Lehr et al., 2003).

A purposeful sample of current state legislation was gathered in order to compare laws of states regulated by different circuit courts. The legislation described below is from states in 8 of the 10 federal circuit courts. This type of sampling was chosen because circuit court decisions related to alternative schools would affect subsequent legislation and litigation in all states in the given circuit. A review of the laws indicates varying levels of specificity in the laws referring to alternative schools. Except in the few 
cases specifically noted below, legislation does not include references to students with disabilities. While this sampling focused on alternative schools in general, it is possible that state law addresses special education placements in separate sections of the law. For example, the Illinois Administrative Code includes a subchapter that focuses on nonpublic schools used for special education placements. These do not meet the definition of alternative schools and are not included with the state's alternative education legislation; however, they do provide an alternative setting in which to educate students with disabilities. Again, there is confusion about how schools are defined, where special education students are being educated, and the extent to which states are accountable for those settings.

California (California Codes, Education Code, Section 56360-56369, n.d.) gives school districts the right to establish their own alternative schools; however, the legislation refers only to the innovative instruction and learning and the importance of alternative schools in maximizing opportunities for learning. There is no reference to using alternative schools for disciplinary reasons. California also gives public school districts the right to contract with nonpublic schools in order to provide special education services in alternative settings.

In Illinois law (Illinois School Code, 2009), the section addressing alternative schools includes a definition of disruptive students as those in grades 6 to 12 who are eligible for suspension or expulsion. Illinois notes that alternative schools are for the purpose of creating a safe educational environment for all students. The law does specifically state that Individualized Education Programs (IEPs) will continue to apply for students with disabilities unless they are modified by the students' IEP teams. 
Nevada law, like that of Illinois, emphasizes the role of alternative programs in dealing with discipline problems (Nevada Revised Statutes, 2010). The law gives districts permission to enroll suspended or expelled students in alternative programs, independent study, distance education, or charter schools that are designated to deal with students who have disciplinary problems. However, unlike Illinois law, the Nevada statute clearly indicates that even alternative programs have the right to review a student's disciplinary record and the incident resulting in expulsion. The alternative program may then reject a student's enrollment if the student will be too disruptive.

Alternative education programs in Pennsylvania are included in the section of the law entitled "Disruptive Student Programs" (Pennsylvania School Code, 1997). The law states that students receiving special education services are not disruptive students except in specific cases, which correspond to situations that would allow students to be placed in Interim Alternative Educational Settings (IAESs). Federal law allows unilateral placement in an IAES in specific cases involving drugs, weapons, or serious bodily injury. In Pennsylvania alternative schools, teachers must be certified, instruction must recognize students' needs, and programming must address the disruptive nature of student behavior. In addition, alternative schools are available only in cases where traditional discipline has been exhausted and failed or student behavior is so severe that it must be addressed immediately.

In Oklahoma (School Laws of Oklahoma, 2009), money for the establishment of alternative schools is available first to districts in which there are a high number of dropouts or referrals to the juvenile justice system. Programs funded by the state must ensure small class sizes, have an eligibility process monitored by intake and screening 
procedures, maintain courses aligned with state standards, include individualized instruction, serve students in grades 6 through 12, plan for the graduation of each student, and include social services and counseling. The law also provides financial incentives for teachers employed and allows for abbreviated day schedules at alternative schools.

Oklahoma mandates that students attending alternative schools be able to participate in extracurricular, vocational, and graduation activities if they meet the requirements, and the state requires that districts spend the same amount of money per student on students who attend alternative schools as those who attend in district schools.

Massachusetts provides grants to districts as well as charter schools to establish alternative programs for students who have been suspended or expelled from school (General Laws of Massachusetts, 2010). Funding may be used to support a variety of initiatives including the hiring of behavior specialists, creation of crisis centers, and the use of technology to set up new or support existing alternative settings. Massachusetts programs must include instruction driven by state standards, small class size, social services to address the issues contributing to the student's truancy or failure, and a remediation plan addressing academics and behavior for every student. Flexible scheduling is an option. Emphasis is also placed on the need for program evaluation and the expectation that students will be reintegrated into general education classrooms.

Ohio law authorizes alternative schools "to serve students who are on suspension, who are having truancy problems, who are experiencing academic failure, who have a history of class disruption, who are exhibiting other academic or behavioral problems specified in the resolution, or who have been discharged or released from the custody of the department of youth services" (Ohio Revised Code, 2004, p. 1). This is later clarified 
as students who are disruptive and low-performing. The statute includes the possibilities of a uniform requirement, restrictions on participation in extracurricular activities, and the establishment of an alternative program in an existing district building. Assessment, progress monitoring, a social services plan, programming for students enrolled in Grades 6 to 12 , and plans for students' transition back to district schools are required.

Iowa's statute focuses specifically on students who have dropped out or are at risk of dropping out (Iowa Code, 2009). It places the responsibility for setting up and maintaining the program with the district. Iowa law is also specific about the confidentiality of records for students who attend alternative schools and the fact that their attendance is voluntary.

While the U.S. Department of Education's definition does not address the use of alternative schools for disciplinary purposes, the brief sampling of laws indicates that a number of states have chosen to use alternative schools as discipline placements. Illinois, Nevada, Pennsylvania, Massachusetts, Ohio, and Iowa laws state that alternative schools are for students with discipline issues, those who have been suspended or expelled, those who have dropped out, or those who are at risk for these situations. California and Oklahoma laws emphasize innovative instruction and the inclusion of particular services, but Oklahoma targets funds to communities that have drop out and delinquency problems. Students with disabilities may qualify for admittance to alternative schools based on discipline criteria; however, the state laws reviewed do not specifically address whether students with disabilities are to be included in alternative school populations. State laws do not assist in the clarification of alternative schools' role in the education of students with disabilities. 


\section{Students Served}

Both the 1998 (Katsiyannis \& Williams) and the 2003 (Lehr et al.) studies included information about the students enrolled in alternative schools; this did not change significantly between the two studies. Limited data have been released from the 2007-2008 study (Carver et al., 2010), so it is unclear whether student characteristics have changed. As noted above, the students' qualities put them at risk for school failure. Students who attended alternative schools had been suspended, expelled, truant, disruptive, involved in criminal activity, or academically unsuccessful. Again, the students were increasingly those who had not found academic or behavioral success in their home schools. Van Acker (2007) focused on programs specifically designed to educate students whose behavior was considered antisocial or aggressive and noted that programming must be specifically designed to neutralize the values and beliefs supporting such behavior. While noting that school-wide initiatives like Positive Behavior Interventions and Supports (PBIS) showed greater effects than individual interventions, Van Acker (2007) listed the following as producing results for individuals: psychotherapy, applied behavior analysis, cognitive-behavioral therapy, social development interventions, and case management. By definition, alternative schools are set up to address needs not met, in manners not undertaken by regular schools. These schools may be better equipped to provide both school-wide and individual interventions needed by some students who are unsuccessful in regular schools.

Curriculum. Curriculum and instruction have been noted as important distinguishing elements in alternative schools. Katsiyannis and Williams (1998) noted that a differing instructional methodology was a defining element in state definitions of 
alternative education. Lehr et al. (2003) found that four themes emerged when investigating and assessing the curriculum of alternative schools; the themes reflected the presence or lack of necessary curricular elements. These were that the general curriculum addressing state standards should be included, social services should be available, community service or work programs were incorporated, and instruction should be individualized (p. 11). Two definitions from the laws described above, those from New Jersey and Mississippi, required that each student attending an alternative school have his or her own individualized plan.

\section{Special Education and Alternative Schools}

Rutherford and Quinn (1999) suggested that there are six critical elements of alternative schools serving students with disabilities: (a) functional assessment to identify student needs and deficits, (b) a functional curriculum designed to meet those needs, (c) effective instruction including direct instruction, (d) transition programs addressing the behaviors that caused student removal from traditional public school, (e) comprehensive systems to address students' global needs, and (f) sufficient special education staff and resources. By 2003 , only $38 \%$, or 18 states, addressed students with disabilities in their alternative school legislation (Lehr et al., 2003). Only one common element was found: alternative schools must follow all state and federal laws that govern the education of students with disabilities. State legislation cited due process rights, the least restrictive environment, and discipline as issues specifically important to students with disabilities. In 2000-2001, there were 10,900 public alternative schools in the U.S.; 612,900 students attended, and approximately $12 \%$ of the students served by these schools were students with disabilities (Kleiner et al., 2002). Since this was a national average, the percentage 
of students with disabilities attending alternative schools covered a wide scope, ranging from 3-20\% of enrollments. By 2007-2008, the reported number of alternative schools was 10,300; these schools enrolled 646,500 students of whom 90,300 received special education services (Carver et al., 2010). Gorney and Ysseldyke (1993) found that in Minnesota $19 \%$ of students in alternative schools were students with disabilities and half of those were students with emotional disabilities (ED).

To refine the relationship of students with disabilities and alternative schools, the ASRP interviewed and surveyed state directors of special education or their designees. A series of reports, referenced below, were published to discuss the results of the ASRP. The studies noted that little information existed about the provision of services to students with disabilities in alternative schools, including IEP implementation, transition, and assessment (Lehr, Moreau, Lange, \& Lanners, 2004).

Because data may not be routinely collected and/or because some students shed their label upon entrance into the alternative school, the number of students with disabilities attending as well as the number of students who graduate or obtain a General Education Development (GED) certificate through these programs is uncertain. (Lehr \& Lange, 2003a, p. 2)

It was also uncertain how often alternative schools were used as IAESs for students with disabilities who had committed drug, weapon, or serious bodily injury offenses.

Lehr and Lange (2003b) conducted interviews with state directors of special education, or their designees, of 48 states and the District of Columbia. Interviewees indicated that alternative schools frequently had an emphasis on behavior improvement, that students enrolled both by choice and because they were compelled to do so, that curriculum was flexible, that alternative schools were located at home schools and in 
alternate settings, and that class size was small. State directors described students as being primarily high-school age and at risk for school failure for a variety of reasons.

Although many of the directors of special education in the Lehr and Lange (2003b) study thought that most of the students with disabilities served in alternative schools were those with ED, they had little or no information on the numbers of students served. Directors indicated that students with disabilities might have been served without IEPs within small settings and using the individualized instruction already in place at the alternative school, that their IEPs may have been adjusted according to what the school was able to provide, or that they may have been served at levels commensurate with those provided by their home schools. The idea that the structure of alternative schools may meet students' needs without IEPs is interesting given that "some alternative educators believe that students who receive special education should not be served in alternative schools because they already have funding and a set of supports in place" (Lehr \& Lange, p. 7). This makes one wonder why students with disabilities might be placed and perform better in properly structured settings even without the benefit of IEPs.

Directors and designees in Lehr's and Lange's (2003a) study expressed concerns about whether or not enrolling students with disabilities in alternative schools violated the requirement to educate them in the least restrictive environment with their nondisabled peers. Although the majority of students attending alternative schools were students without disabilities, all were classified as at risk. "A major issue is the isolation of these schools. Even in 'schools within schools,' these kids are isolated from others. Ironically, this is similar to special education in the past where kids were segregated from others" (Lehr \& Lange, p. 10). 
Surveys. Personnel from 39 states responded to surveys that Lehr et al. (2004) administered. In many ways, responses mirrored those from the interviews. The purpose of the programs was again stated as educating and graduating at-risk youth, and the categories of students identified were the same. Survey responses added that the alternative school placements should be short term and that instruction should be tailored to individual student learning styles. Through surveys, 20 state designees offered enrollment numbers: 1,023,260 students attended alternative schools during the 2001-2002 school year (Lehr et al., p. 11). However, as stated by interviewees, little was known about the number of these students who qualified for special education services or the services those students received. Students with ED were again listed as a group attending alternative schools in large numbers; students with learning disabilities and other health impairments were added to the list. Most of the time, these students' IEPs were changed to reflect needs as well as what the alternative school could provide. Alarmingly, however, $41 \%$ of respondents indicated that termination of services, suspension of services while at the alternative school, and/or lack of knowledge of student services were likely to occur (Lehr et al., p. 19). Measurement of outcomes from either interviews or surveys indicated that minimal data were collected on this topic. This lack of data collection is notable given that anecdotal reports of student outcomes are copious and past research has indicated positive student effects (Lehr, 2004).

Atkins et al. (2005) studied alternative schools for students involved in the juvenile justice system. The authors selected three schools to study: one urban private school, one urban public school, and one rural public school. All of the schools served students with and without disabilities. None of the schools offered intensive special 
education services, and one provided none at all, but all offered community services like parenting classes, job placement, and counseling. Both students and staff believed that the level of services met the needs of students, whether or not these services were provided by special education teachers. In addition, teachers judged students' IEPs to be unhelpful in educating students with disabilities.

\section{Alternatives to the Alternative School}

Various authors have listed a number of types of alternative settings that might or might not have met the Department of Education definition of alternative school. The alternative classroom, charter school, school within a school, distance learning program, educational center, residential school, separate alternative school, continuation school, court school, detention school, day treatment school, alternative learning center, and magnet school have been named as models (Gable, Bullock, \& Evans, 2006; Katsiyannis \& Williams, 1998). Not all of these schools were set up within public school districts and may not have been included in the ASRP's studies. Charter schools and distance learning programs were publicly funded; however, state definitions indicated that it was likely that these were not included in the ASRP's early research (Lehr et al., 2009). The difference in state definitions for alternative schools and the increasing number of private schools that provide alternative placements exclusively for students who receive special education services indicate that the information provided by states may or may not provide a clear picture of students who receive education in settings away from their home schools.

It is apparent, then, that the vast number of research projects undertaken by the ASRP still did not address the concerns related to the inclusion or exclusion of students with disabilities and the services they were provided in alternative placements. Bullock 
(2007) noted that the expansion of alternative schools may be due to school expectations that do not match student performance. The increase in the numbers of students who had been placed in alternative schools due to disrupting the learning environment or the danger they posed to others did serve to further segregate these students, and that segregation may have been disproportionate for students with disabilities (Lehr et al., 2009). Students with disabilities attend many schools that are private, and these were not addressed by the ASRP's first study nor were they included in the U.S. Department of Education's definition of alternative education school. A study of Oregon schools reinforced this idea, noting that $73.8 \%$ of districts operated alternative schools and $62.8 \%$ used privately operated placements. The study also indicated an obvious overrepresentation of students with disabilities in alternative schools: $32 \%$ versus $11 \%$ of all students in the state (Unruh et al., 2007, p. 3). Of those eligible for special education services, students with ED were the most overrepresented in more restrictive settings; they made up the majority of students placed in residential and day treatment schools and were placed in more restrictive settings than any other identified group (Gagnon \& Leone, 2006; Muscott, 1997).

Quinn et al. (2006) studied three alternative programs, focusing on school climate. The programs were selected because of the different students they served. One was a public program that provided services at a number of different sites including community day schools and correctional facilities. The second program was public, university-run, and operated a single site that educated students with disabilities from surrounding school districts. The last program was operated by a nonprofit mental health agency. The findings of this study were that, across the different types of placements, "these 
alternative programs create personalized environments in which students feel respected and fairly treated and where expectations for social, interpersonal, and academic success are supported" (Quinn et al., 2006).

Because the concept of alternative schools remains confusing, I will take a broader view of alternative schools and include public or private educational placements that serve students with disabilities outside their home schools. I discuss these in the next sections in order of increasing restrictiveness.

Charter schools. The U.S. Department of Education (2004) defined charter schools as:

...independent public schools designed and operated by parents, educators, community leaders, education entrepreneurs and others. They operate with a contract, or charter, from a public agency, such as a local or state education agency, an institution of higher education or a municipality. (p. 1)

While not private, charter schools may not have been included in the ASRP studies. As schools funded by public monies, charter schools are held to the same standards as public schools as far as providing legal protections and special education services; however, many charter schools are defined for specific purposes. These may be in conflict with the "zero reject" principle of IDEA (Estes, 2004). Thus, while charter schools were intended to be a school-choice option, that choice may not be available to students with disabilities.

Traditionally, students with disabilities in charter schools have been those with mild to moderate disabilities, and their percentage has been smaller in these schools than in public schools (Estes 2001, 2004, 2009). While 12\% of the students in Texas' traditional public schools were identified as students with disabilities in 1999-2000, the percentage of these students in charter schools was $8.6 \%$ (Estes, 2001). Nationally, 9\% 
of students in charter schools and $12 \%$ of students in public schools were students with disabilities (U.S. Department of Education, 2004). This national review found that while charter schools were less likely to serve students who received special education services, they were more likely to serve students from minority and low-income backgrounds. In a later study of charter schools in Texas, Estes (2009) found that schools with populations of students with disabilities greater than $20 \%$ were chartered specifically to serve those students, but that all charter schools in the state served students with disabilities. This study also found that the percentage of students with disabilities served in charter schools had increased to $12.5 \%$, making enrollments comparable to those in public schools.

Estes (2009) found information that gives pause. First, administrators of charter schools reported that they were much more concerned with the mandates of the NCLB Act than with those of the IDEA. Only $20 \%$ of these administrators reported that prereferral interventions took place in their buildings, and only $60 \%$ followed the requirements of holding manifestation determination meetings when necessitated in cases of suspension or expulsion. Next, the structure of special education in charter schools had moved from full inclusion in the 1999-2000 school to a resource room model. This may have represented a better understanding of the continuum of services or may have indicated a move toward exclusion of students with disabilities. Finally, Estes recommended that further research be conducted to determine the academic success of students with disabilities in charter schools, noting that the achievement of general education students in charter schools lags behind that of their peers in traditional public schools. The U.S. Department of Education, Office of the Under Secretary (2004) indicated that charter 
schools have had trouble reaching the academic standards set by the NCLB Act; charter schools were less likely to meet standards than traditional public schools.

Regional Safe Schools. In Illinois, the Regional Safe Schools Program (RSSP) meets the federal definition of alternative schools. RSSP schools are public and were designed to provide programming for youth who are too disruptive and have been suspended or expelled from their home schools. Students eligible for special education services may attend RSSP schools, but only if the decisions to do so are made by their IEP teams. During the 2005-2006 school year, 5,671 students attended RSSP schools and approximately $12 \%$ were students with disabilities (Illinois Regional Safe Schools Program, 2006). Because RSSP schools offer few special education services, special education students may have been excluded because they require a higher level of service than the programs are able to provide. When they do attend, students with disabilities continue to receive services listed in their IEPs, or their IEPs may be "appropriately modified" to better align with the services available at the schools (Koch, 2001). All students enrolled in RSSP schools should have Alternative Education Plans; data indicated that over $90 \%$ did have these plans during the 2005-2006 school year (Illinois Regional Safe Schools Program, 2006). Alternative Education Plans are similar to IEPs in that they detail students' needs and services; however, the Alternative Education Plans should also state a plan for students' transition back to their home schools. Students with disabilities continue to be protected by due process rights while attending RSSP schools. In 2001, there were 100 RSSP sites across the state of Illinois (Koch, 2001).

Public-private partnerships. Public-private partnerships have the potential to marry resources of a number of systems that can support students in alternative schools. 
The education background of public school personnel can be complemented by the therapeutic expertise of mental health personnel and counselors. The Alternative School Program (Wetzel \& McNaboe, 1997) provided one example of this model. This model created a district program that contracted with outside agencies to provide specialized staff to work within the school. While encouraging reintegration into the public school setting, the teams in this program found that extensive focus on and review of interventions for individuals helped those individuals and created systems change. Teams were able to apply interventions across settings to affect regular schooling. In this manner, the alternative school had become a laboratory for effective practice for students with behavioral challenges.

Therapeutic schools. Therapeutic schools, often called day treatment schools or therapeutic day treatment schools, educate children in settings that combine special education and mental health services (Gagnon \& Leone, 2006). Males, African Americans, and students with ED have been overrepresented historically in therapeutic schools as they have in other highly restrictive placements. Most students spend 2 to 3 years at day treatment schools before returning to less restrictive settings (Gagnon \& Leone). For many, the return is difficult because of higher academic and behavioral standards and a curriculum that does not match that of the more restrictive setting (Gagnon \& McLaughlin, 2004).

One early day treatment school, the Day Treatment Unit of the Rochester Mental Health Center, aimed to modify children's behavior, help them achieve at their ability levels, and return children to their public schools (Gold \& Reisman, 1970). Like other alternative schools, the school purported to teach students using various modalities, was 
attentive to individual needs, and provided both academic and leisure activities. Students spent an average of 16 months in the program and functioned academically below average for their age. Of 48 students for whom follow-up data were collected, 37 were in public schools; 26 of those were still enrolled in special education programs. The 11 remaining children had been placed in institutions. Early identification and intervention proved to be essential in improving student outcomes. After the students left their day treatment setting, the parents of these students rated their children to be relatively well adjusted while public school teachers thought the students were poorly adjusted. This may have been due to the fact that the parents were using their own children, whose behavior had improved drastically, as a reference point, while public school teachers were comparing the students to their peers.

Residential schools. Residential schools are similar to day treatment schools in that they provide mental health and special education services to students; however, residential schools offer more intensive settings, as they provide 24-hour supervision and more comprehensive services to young people. Muscott (1997) noted that the distinction between day treatment and residential settings has more to do with the living situations of the students than with instructional differences; the students in residential settings received essentially the same educational services as those in day treatment, but the residential students also received 24-hour care. The average stay at a residential school is less than 1 year, after which most students move to less restrictive settings. Residential schools are not licensed as hospitals, and are often thought of as the most restrictive educational settings on the continuum of services (Gagnon \& Leone, 2006). The gender, race, and disability overrepresentation seen in day treatment schools is also evident in 
residential settings. Muscott (1997) found that older students with ED in residential settings were less aggressive and disruptive than younger children in the same settings. However, he offered two possible reasons for this: either older students had experienced longer periods of intensive intervention or those with the most maladaptive behaviors had dropped out of school. The same study resulted in the conclusion that adult ratings of the behavior of students from resource rooms, special classes, special schools, and residential settings were not significantly different (Muscott, 1997). While student placement depends on student needs and severity of disability, it may be that appropriate placements mediate inappropriate behavior.

Bratter, Bratter, Coiner, Kaufman, and Steiner (2006) profiled a unique residential school, The John Dewey Academy. It is a voluntary, therapeutic high school attended by students who have undergone mental health treatment, substance abuse treatment, or are psychiatrist- or self-medicated. The school provides moral education, a rejection of psychiatric diagnoses and psychotropic drugs, and a cognitive therapeutic approach to teach self-respect and respect of others. Even more unique is that $100 \%$ of the students at this residential school typically enroll in quality colleges, and more than $70 \%$ typically graduate from college (p. 14).

Nationwide research on day treatment and residential schools is difficult to conduct, because no inclusive list of these schools exists. The Harrisburg Project (2009) identified 481 state-approved, nonpublic residential and day treatment programs for the state of Illinois. Of those, 83 were residential programs and 241 were day treatment programs located in the state. The remaining 157 schools were approved programs that were located outside of Illinois. Even this extensive list is not all-inclusive since the 
public residential and day treatment programs were not included. Illinois law does address the special education approval and placement requirements of nonpublic programs; however, this is contained in a portion of the code that is separate from those that include RSSP and other alternative schools.

Interim alternative educational settings. The reauthorization of IDEA (2004) allows for the unilateral placement of a student with a disability in an interim setting for engaging in the following behaviors while at school or a school function: carrying a weapon, possessing or using illegal drugs, or inflicting serious bodily injury upon another person. An IAES is available for up to 45 days and must allow the student to continue to progress in the general education curriculum, receive the services on his or her IEP, and receive a functional behavioral assessment if needed. School districts may also seek an IAES for a student who is dangerous or disruptive; however, in these cases, the district must prove substantial likelihood of injury if the student remains in his or her home school (Etscheidt, 2006). As stated previously, the extent to which the various types of alternative schools are used as IAESs is unclear. In Illinois, RSSP schools, described previously, often serve as IAESs.

\section{Student Perspectives}

Castleberry and Enger (1998) reported students' perspectives on their own success. The students were asked to contrast their relative success in public and alternative schools. Ninety-five percent of the students felt that they had been unsuccessful in public school and preferred most elements of the alternative placement. Student-teacher relationships and student sense of belonging also contribute to student success in school. Moore, Henfield, and Owens (2008) noted negative student perceptions about school and 
recommended that school personnel should advocate for students with disabilities in order to gain their trust. Students cited teacher relationships and interpersonal relationships as the most important factors contributing to whether or not students liked their schools (Nichols, 2008; Pomeroy, 1999). Teachers' ability to form relationships, willingness to help, capacity to discipline fairly, and ability to educate students contributed to the extent to which students felt positive about their school experiences (Pomeroy, 1999).

Quinn et al. (2006) studied school climates in effective alternative schools, finding that students felt that they were treated respectfully and fairly and that school personnel were open to change. Students

flourish in alternative learning environments where they believe that their teachers, staff, and administrators care about and respect them, value their opinion, establish fair rules that they support, are flexible in trying to solve problems, and take a nonauthoritarian approach to teaching. (Quinn et al., p. 16)

D’Angelo and Zemanick (2009) also emphasized the importance of student-teacher relationships, profiling a successful alternative school whose motto was "give respect to get respect” (p. 215). One study found that at-risk students believe that they perform better in alternative schools (Atkins, Hohnstein, \& Roche, 2008).

Sinha (2007) explored student perceptions of a faith-based alternative school and their previous public school. Many of the students in Sinha's study expressed that there were fights in public school but noted that there were positive peer interactions and a feeling of safety in the alternative school. Other positive perspectives that students expressed about the alternative school were that they could get academic help and pace their work according to their needs, they trusted staff members, and classrooms were more relaxed. Half of the students thought they would be more likely to graduate from the alternative program than they would have been from a public school. None of the 
aforementioned studies on student perspectives specifically included or discussed students with disabilities.

In Tapasak's and Walther-Thomas' (1999) study of student perceptions of educational programming, students only sometimes noted teacher-student relationships as contributing to positive opinions. Tapasak and Walther-Thomas assumed that inclusive classrooms benefitted students with and without disabilities, but noted that research on student perceptions has indicated various findings in this area. A study of a first-year inclusive education program illustrated that young students felt positive about their classroom performance, but older students tended to have more negative perceptions about self and peers (Tapasak \& Walther-Thomas, 1999). A meta-analysis of studies on student perceptions of inclusion indicated that students preferred both inclusion and pullout models of instruction (Vaughn \& Klinger, 1998). Students believed that they learned more in pull-out settings, could work in quiet places, and were less likely to be embarrassed by what they did not know. Benefits to education in the general education classroom were primarily related to social opportunities with expert teachers cited as well.

In looking at educational settings and student placement, some researchers have contrasted student perceptions as related to former and current educational placements. Overall, students had high opinions of school cultures that were well-organized and included strong leadership, teachers who were involved in shared decision making, and positive student-staff relationships (Glover \& Law, 2004). The studies focusing on specific placement types reported on student perceptions of alternative schools (Ghory \& Sinclair, 1978; Kershaw \& Blank, 1993; Saunders \& Saunders, 2001/2002), charter 
schools (Barrett, 2003), vocational schools (Jahnukainon \& Helander, 2007), and transition to community from residential placement (Sadao \& Walker, 2002).

Findings of one study (Ghory \& Sinclair (1978) included the notion that alternative schools could contribute to the difficulties of at-risk students and the authors drew the conclusion that "no single, monolithic school environment is appropriate for the variety of needs and strengths of any large group of students" (Ghory \& Sinclair, p. 40). Insights from students in other studies indicated that they did find smaller settings, more structured environments, and more teacher attention to be valuable (Kershaw \& Blank, 1993; Saunders \& Saunders, 2001/2002). Kershaw and Blank also indicated that a majority of students acknowledged relationships with teachers and guidance counselors as a positive aspect of their alternative schools. Saunders and Saunders (2001/2002) also found that a majority of students indicated a negative perception of their former schools but a positive perception of their alternative schools. Teachers, counselors, and administrators were given high marks at the alternative schools for being fair, helping students with academics, having strong interpersonal relationships, and giving personal attention to students.

Barrett (2003) analyzed surveys completed by students at 62 charter schools and asked students to compare their charter school experience with the experience at their former schools. Overall, students were as pleased or more pleased with their charter school experience. Specifically, students gave higher marks to the charter schools when they believed the following about the schools: teachers were better, gave more attention to students, and cared more; and the environments were more positive, embodied by caring principals, safe environments, orderly classrooms, and a sense of belonging and 
safety for students (p. 355). These positive aspects of charter school experiences were noted especially by students who were labeled at risk for dropping out of their former schools.

Sadao and Walker (2002) interviewed students who were returning to their communities following residential placement. These students were entitled to special education services under the labels of ED or behavior disordered (BD). Students expressed that the level of support they had at their residential placements was high and worried that they would return to their old behavior patterns after leaving the placements. Students were both excited to leave their placements and nervous about a future without the support that they had at the time of the interviews.

Atkins, Hohnstein, and Roche (2008) studied the perceptions of students with and without disabilities about their public and alternative or charter school experiences. The focus campus housed an alternative school and a charter school. Both followed a military model and students attended based on choice. Atkins et al. found through this quantitative survey that students believed that they had improved in the academic, behavioral, and social domains since attending the alternative or charter schools. Negatively, a majority of students reported that they had not decreased their alcohol and drug use and that they had not become better readers. The authors also compared the perceptions of students with and without disabilities, finding a difference in only one area. Students with disabilities in the alternative or charter schools had a better academic attitude than their peers without disabilities. 


\section{Chapter Summary}

As noted in this chapter, there continues to be a dearth of research on alternative schools and students with disabilities. While a federal definition exists for "alternative education school," that definition encompasses only a small fraction of the educational settings that provide services for students with disabilities who do not attend their home schools. A further exploration of state definitions illustrates that many states have taken the concept of alternative education school and refined it to mean discipline school. The question then becomes whether alternative education schools are designed to better meet the needs of students or to meet the need of schools to maintain order. Are alternative schools merely to house students who are mandated to attend schools but not wanted by their public schools? Lehr et al. (2009) asked, "Is the underlying intent of alternative education legislation to meet the needs of disenfranchised students, or to assist traditional public schools in behavior management?" (p. 31).

Definitional issues create an even more difficult situation in calculating where students are educated because their educational environments may not be included in those that are counted, studied, or held accountable. While it had originally been my intention to present a nationwide picture of the settings in which students with disabilities are educated, it seems that the data needed to do that do not exist. There is no comprehensive survey of where school districts are educating their students with disabilities, since many settings where students with disabilities are educated were not included in the nationwide surveys of the 2000-2001 and 2007-2008 school years. In the absence of national data, I used the data from CUSD to illustrate the way that definitional issues mask the number of students with disabilities who are educated in settings other than 
their home schools. The data from CUSD indicate that a number of students with disabilities are educated outside of the district, outside public schools, and outside federal counts of those educated in alternative schools. The use of alternative placements, particularly private placements, may be a way for public schools to exclude students exhibiting inappropriate behavior, whether or not those students have disabilities.

My review of foundational literature indicates that there are topics surrounding alternative schools, particularly alternative schools that serve students with disabilities, that have yet to be explored. In order to ensure that students with disabilities receive the education to which they are entitled, including special education and related services, we need a more encompassing view of the environments in which students are educated. With greater scrutiny will come a better understanding of services provided, the over and underrepresentation of certain groups in different placements, and closer alignment of curriculum with standards. Special education services must be provided to students regardless of their educational environments, and the schools charged with providing those services must be held accountable.

In addition, we need a clearer understanding of students' perspectives on their own educational experiences. Only when we have a clear picture of the number of students being educated in all placements and when we know the views of students toward those placements will the needs of these students be apparent. The education of students with disabilities must be dictated by their needs rather than by institutional needs. 


\section{CHAPTER III}

\section{METHODOLOGY}

This chapter includes a description of the qualitative research methodology I used to explore the perspectives of students with disabilities who attend regional safe schools. Denzin and Lincoln (2003) explained this methodology in the following manner: "qualitative research involves an interpretive, naturalistic approach to the world. This means that qualitative researchers study things in their natural settings, attempting to make sense of, or to interpret, phenomena in terms of the meanings people bring to them" (pp. 4-5). Berg (2004) added that:

qualitative research properly seeks answers to questions by examining various social settings and the individuals who inhabit those settings. Qualitative researchers, then, are most interested in how humans arrange themselves and their settings and how inhabitants of these settings make sense of their surroundings through symbols, rituals, social structures, social roles, and so forth. (p. 7)

\section{Purpose of the Study}

The purpose of this study was to investigate the perspectives of students with disabilities who attend a regional safe school on their schooling experiences. The study focused on the viewpoints of students who attended a regional safe school located in a small urban community. I conducted one-on-one interviews with eight students of high school age to gain their perspectives on the strengths and weaknesses of their home schools and alternative school. I asked the participants about factors they think have helped and hindered their successes in both home schools and the regional safe school. 


\section{Research Questions}

The following research questions guided this study:

5. What are the perspectives of students enrolled in a regional safe school regarding their experiences in their home schools and regional safe school?

6. What are the perspectives of students enrolled in a regional safe school regarding strengths and weaknesses of the services and programming received at their home schools and at the regional safe school?

7. What are the perspectives of students regarding the effectiveness of their schooling in their home schools and regional safe school?

8. What do students identify as the key elements to their success in school, and what are their comparative perspectives on how their home schools and regional safe school address those elements?

\section{Research Design}

Mason (1996) noted that in spite of attempts to define qualitative research in a consistent manner, consensus does not exist, "because qualitative research certainly does not represent a unified set of techniques or philosophies" (p. 3). There are, however, descriptions of qualitative methodology that contain consistent features. Bogdan and Biklen (2007) listed five elements of qualitative methodology: it is naturalistic, contains descriptive data, is concerned with process rather than merely product, is inductive, and is concerned with how people make meaning of their lives (pp. 6-7). Creswell (2007) agreed with these elements, adding that qualitative research draws from multiple data sources, has the researcher as the data collection instrument, and presents a holistic account "identifying the complex interaction of many factors in any situation" (p. 39). I selected qualitative methodology to address the current study's research questions because it allowed me to provide thick, rich descriptions of the participating students' experiences. 
Qualitative research may have its basis in existing theory, such as feminism or critical race theory, or it may create new theory about the issues, subjects, or situations on which it is focused. The building of a new theoretical perspective, grounded theory, helps qualitative researchers to "hear silenced voices" and understand the perspective of a group relative to a specific issue (Creswell, 2007, p. 40). Charmaz (2003) added that in grounded theory, specific guidelines are used to allow researchers to create theory to explain the data that have been collected.

The strategies of grounded theory include (a) simultaneous collection and analysis of data, (b) a two-step data coding process, (c) comparative methods, (d) memo writing aimed at the construction of conceptual analyses, (e) sampling to refine the researcher's emerging theoretical ideas, and (f) integration of the theoretical framework. (Charmaz, 2003, p. 251)

I used a grounded theory approach for this study because it allowed me to complete indepth analysis of my student interviewees' perspectives.

I selected collective case design (Stake, 1995, 2006) for this study because the purpose of the research was to understand an issue through comparison of the individual cases. I did not seek to generalize the findings of this research to other cases but to provide an in-depth analysis of the experiences of the individuals I studied. Miles and Huberman (1994) noted that the purpose of this type of research is "to see processes and outcomes across many cases, to understand how they are qualified by local conditions, and thus to develop more sophisticated descriptions and more powerful explanations" (p. 172). I conducted cross case analysis (Miles \& Huberman, 1994) to deepen my understanding of the perspectives of my student participants and identify "themes that cut across cases" (p. 174). 
The perspective of students with disabilities attending therapeutic schools was the focus of a previous study (deGruy, 2009). In that study, I interviewed members of this specific group of the larger population of students with disabilities in order to determine their opinions on the strengths and weaknesses of their therapeutic and public school experiences. Findings of the study indicated that students felt that they benefitted from smaller settings, that positive teacher relationships helped them, and that they had experienced traumatic situations without support in their public schools. The current study sought to determine the extent to which these findings would be consistent for students who attend alternative schools for disciplinary rather than disability reasons.

Qualitative methodology, which included the collective case method and crosscase analysis, served as the most appropriate vehicle for addressing this study's research questions and representing the participants' viewpoints. All participant perspectives are reflected in the report of the analysis and findings; participants expressed their views on strengths and weaknesses of their home and alternative school placements.

\section{Sampling Plan}

In this study I used purposive sampling to identify a specific group of participants who represented the population of interest (Berg, 2004). Miles and Huberman (1994) noted that qualitative sampling is theory driven rather than random because of the need to focus on a specific group of participants that relates directly to the research questions and helps researchers to form theories. "This sampling strategy is broadly intended to facilitate a process whereby researchers generate and test theory from the analysis of their data, rather than using data to test out or falsify a pre-existing theory" (Mason, 1996, p. 100). 
The population of interest in this study was students with disabilities who attended a regional safe school. I designed the research questions with a focus on the educational experiences of those students.

\section{Researcher as Instrument}

As a former high school and middle school teacher, I began the observation and interview process with a sense of security about my ability to establish rapport with participants. Although I was an outsider in the close-knit community of an alternative school, I was able to relate to many of the students as a former high school teacher. I used my experiences as a teacher, as well as other personal information, to put students at ease during interviews. I spoke about the careers of my family members when students spoke of their career aspirations; I offered information about my high school mistakes when students discussed theirs; I reinforced the idea that some experiences are private when students declined to address certain topics.

I attempted to interview students in an environment that was relaxed and supportive. I sat near students, but did not enter their personal space, and did not put a table between us during interviews. Although I had an interview protocol, I allowed students to direct much of the discussion. I reminded students that any information that they shared would be confidential and informed them that they would not offend me with their answers, even if they though those answers were inappropriate. Students showed their ease with me by greeting me in the school environment when peers were present, requesting that I help them with work that they may have missed during the interview, and for one student, asking if I could introduce her to a trustworthy adult as she transitioned to her home school. 


\section{Participants}

\section{School Participants Attended}

I have assigned pseudonyms to all schools, including the safe school and students' home schools, named in this manuscript. The students in this study attended a regional safe school. The safe school, the Hope Academy, is located in a small urban community in the Midwest and is operated by the Regional Office of Education. It serves middleand high school-aged students from 17 school districts in two counties. During the 20092010 school year, Hope Academy served 233 students; the average population of the school is 150 to 180 students (FY 2010 End Year Report, 2010). Hope Academy is designed as an option for students "who have been multiply suspended or are on the verge of being expelled from school for acts of gross misconduct" (www.roe9.k12.il.us, 2009); $53.2 \%$ of the students served during the 2009-2010 school year were expulsion eligible or had been expelled and readmitted (Hope Academy FY 2010 End Year Report, 2010). In addition to academic programming, the Hope Academy curriculum includes social skills training, job training, partnerships with mental health agencies, and drug and alcohol counseling.

Hope Academy serves students with and without Individualized Education Plans (IEPs). In general, the students with IEPs who attend Hope Academy are those with high incidence disabilities (i.e., specific learning disabilities, emotional disabilities, speechlanguage impairments, or mild cognitive disabilities). These students continue to receive special education services while at Hope Academy; however, IEPs may be modified to reflect services available. While students attend Hope Academy, their case management continues to be the responsibility of their home school districts. At the time this study 
was conducted, students with disabilities made up $25.3 \%$ of the population of Hope Academy. Approximately $66.1 \%$ of the school's population was male, $59.5 \%$ was African American, and 36.9\% was Caucasian. On average, $87 \%$ of the students at Hope Academy received free or reduced lunch.

\section{Eligibility Criteria}

To be eligible for participation in this study, students had to be enrolled in the regional safe school previously described. They were students enrolled in middle or high school grades and had attended their public home schools for some portion of middle or high school. All students in this study had IEPs and received special education services while at their home schools and while attending Hope Academy. Participation in this study was not contingent on the students being served under a specific disability category; I have reviewed their individual characteristics in the Participants section of this chapter.

\section{Recruitment}

After securing approval of the study by the university Institutional Review Board, I sent a letter to the Director of Alternative Education to request permission to observe classrooms and conduct research at the school (see Appendix A for a copy of this letter). I asked her to identify students who received special education services and were enrolled in alternative education middle or high school programs. The director then sent letters to the parents of these students who then contacted me or returned the Parent Permission Form if they were interested in having their children participate in the study (see Appendix B for a copy of the recruitment letter).

As a result of parents' completion of the Parent Permission Form, I identified 9 students for participation through the verbal or written commitment of their parents. A 
$10^{\text {th }}$ student was 18 years old at the initiation of the study; he signed consent to participate. The director of the program provided students with an incentive, a free item from the a la carte menu at lunch, to return their permission forms; she gave the incentive to all students who returned the signed form, whether or not the parent granted permission to participate. I was unaware of this incentive until after she returned all of the consent forms to me. I obtained informed assent from students at the time of our first interviews (see Appendix C for the Parent Permission Form and Appendix D for the Child Informed Assent Form).

\section{Selection of Participants}

Ten respondents returned parental permission forms. Of these 10, one did not assent to participation. A second student signed assent but withdrew from the study during the first interview. The remaining 8 students who met the eligibility criteria participated in the study. Although eligibility for participation stated that students could be of middle or high school age, all participants who had parental permission and assented were in high school at the time of the interviews. Table 2 contains information on each of the participants.

\section{Participant Descriptions}

I did not review individual student records as part of this study; therefore, all descriptions were derived from personal information that the students reported. Although all students who participated in this study were students with IEPs, my knowledge of their disability categories was limited to information that students chose to disclose. My perceptions of each participant follow their individual descriptions. 
Table 2

\section{Participant Demographics}

\begin{tabular}{|c|c|c|c|c|c|c|c|}
\hline Student & Gender & Age & Grade & Ethnicity & $\begin{array}{l}\text { Home high } \\
\text { school }\end{array}$ & $\begin{array}{l}\text { Length of } \\
\text { attendance on } \\
\text { date of first } \\
\text { interview }\end{array}$ & $\begin{array}{l}\text { Interview dates } \\
\text { and length }\end{array}$ \\
\hline Thomas & Male & 18 & 12 & Caucasian & Washington & $\sim 3$ years & $\begin{array}{l}\text { 11/22/2010, } \\
17: 06\end{array}$ \\
\hline Evan & Male & 16 & 11 & Caucasian & Washington & $\begin{array}{l}\sim 1 \text { year } \\
\text { (twice) }\end{array}$ & $\begin{array}{l}\text { 11/19/2010, } \\
\text { 17:37 } \\
\text { 1/10/2011, 40:34 } \\
\text { 1/18/2011, } 20: 46\end{array}$ \\
\hline Bobby & Male & 17 & 11 & Caucasian & Jefferson & $\sim 4$ years & $\begin{array}{l}1 / 7 / 2011,23: 12 \\
1 / 25 / 2011,24: 30 \\
1 / 27 / 2011,16: 43\end{array}$ \\
\hline Zach & Male & 17 & 12 & $\begin{array}{l}\text { African } \\
\text { American }\end{array}$ & Adams & $\sim 3$ years & $\begin{array}{l}\text { 12/10/2010, } \\
16: 34 \\
\text { 1/4/2011, } \\
\text { 1:09:22 } \\
\text { 1/25/2011, 18:07 }\end{array}$ \\
\hline Luke & Male & 17 & 12 & Caucasian & West & $\sim 1$ year & $\begin{array}{l}11 / 23 / 2010, \\
13: 42 \\
1 / 4 / 2011,34: 12 \\
1 / 18 / 2011,14: 43\end{array}$ \\
\hline Isaiah & Male & 16 & 11 & $\begin{array}{l}\text { African } \\
\text { American }\end{array}$ & West & 3 days & $\begin{array}{l}12 / 6 / 2010,13: 19 \\
1 / 10 / 2011,22: 29 \\
1 / 18 / 2011,12: 11\end{array}$ \\
\hline Hailey & Female & 16 & 11 & $\begin{array}{l}\text { African } \\
\text { American }\end{array}$ & West & $\sim 10$ months & $\begin{array}{l}\text { 11/23/2010, } \\
17: 40 \\
\text { 1/5/2011, 29:43 } \\
1 / 20 / 2011,15: 33\end{array}$ \\
\hline Andrea & Female & 16 & 11 & $\begin{array}{l}\text { African } \\
\text { American }\end{array}$ & East & $\sim 1 / 2$ year & $\begin{array}{l}11 / 23 / 2010,13: 18 \\
1 / 20 / 2011,29: 09 \\
1 / 27 / 2011,10: 49\end{array}$ \\
\hline
\end{tabular}

Thomas. Thomas was Caucasian and an 18-year-old senior. At the time of the first interview, he had attended Hope for approximately 3 years, having begun his attendance during his freshman year. He had attended three elementary schools that he 
remembered, although he said that there might have been more. He attended junior high and began high school prior to enrolling at Hope. Although Thomas indicated that he had come to Hope because he was an outcast at his previous school, he also identified behavioral difficulties that he had there. Thomas was interested in working with mechanical things and had worked in plumbing and heating with his father since an early age. He also enjoyed riding dirt bikes and driving his car. Thomas was involved with the adult court system, having several court dates during the times that I conducted interviews; however, he did not divulge the nature of his involvement.

Thomas lived in a small rural community, having attended Washington High, which enrolled students from a number of surrounding small rural communities. Interscholastic sports were an integral part of student life at Washington, which had won several state titles in football and basketball. Washington had a population of approximately 470 students, of whom 94\% were Caucasian and $19 \%$ low income. Thomas had no desire to return to Washington prior to finishing high school.

I interviewed Thomas on only one occasion; the length of that interview was 17 minutes 6 seconds. I attempted to interview Thomas on three other occasions; however, he did not want to speak to me on those days. He did grant permission for me to use the data from his first interview, and met with me to review his perceptions and quotes. Although he had been at Hope for 3 years, of all of the participants, he was the angriest with his home school at the time of his interview. It was difficult to build rapport with Thomas, but by the end of the first interview, he did show me a smile.

Evan. Evan also attended Washington High prior to enrolling at Hope Academy. He was a 16-year-old junior and was Caucasian. Evan reported that he had a learning 
disability and Attention Deficit Hyperactivity Disorder (ADHD). He had attended Head Start, three elementary schools, a junior high, and a high school. Evan had attended Hope for a little over a year during his seventh and eighth grade years and returned to Washington to begin high school. After an unsuccessful year and a half, Evan came back to Hope in the middle of his sophomore year. He had been enrolled there for approximately one year at the time of his first interview. Evan was interested in riding bikes, playing football and hockey, and had been a golden glove boxer. He lived with both parents and had an older brother and younger sister. Evan stated that he had chosen to attend Hope but that he had been suspended multiple times for his behavior prior to leaving Washington.

Evan eagerly participated in the three interviews that I conducted with him, and I established rapport very easily with him. The interviews ranged in length from 17:37 to 40:34. He was disappointed at the end of the third interview, when I informed him that I might not be back to interview him again. Evan shared information about his family and past school experiences and was not upset about his past negative experiences.

Bobby. Bobby was 17 at the time of his first interview and was looking forward to turning 18 in a few months. He was a junior, Caucasian, and had attended Hope since the middle of his seventh grade year; he had been a student at Hope for approximately 4 years. He was a student with a learning disability and reported that he had been moved to Hope in lieu of an expulsion because he had a weapon on the bus. Bobby had attended two elementary schools and a junior high before moving to Hope. He planned on entering the marines when he graduated from high school, following in the footsteps of both of his grandparents who had been in the military and served in Vietnam. Bobby 
enjoyed playing hockey and football in his free time and was looking forward to playing on the football team of his home high school during next school year. Bobby lived with his maternal grandparents. He had served time in a juvenile detention center, related to an incident that happened at school, about a year prior to his first interview.

Bobby was in the process of transitioning back to his high school, Jefferson High, a consolidated high school enrolling students from seven communities and covering parts of five counties. He lived in one of the very small communities served by Jefferson; it had about 300 residents. The school had a population of about 460 students of whom more than $97 \%$ were Caucasian and $23 \%$ low income. Jefferson was located in a county neighboring that of Hope, and Bobby had a bus ride of approximately one hour to come to school.

I interviewed Bobby three times. The interviews ranged in length from 16 minutes 43 seconds to 24 minutes 30 seconds. Bobby was agreeable about participating in interviews and shared much personal information. On one occasion, there was insufficient time between my arrival to interview him and the time that he needed to leave for classes at his home school. At that time and during our subsequent meeting, he reminded me of his schedule to ensure that we were able to meet. Bobby had many questions about my father's military experience, and this helped us to establish a strong rapport.

Zach. Zach reported that he loved to play sports, particularly gymnastics, in spite of his asthma. He was a 17-year-old senior who was African American. He was looking forward to going to college and working with electronics after graduation. Zach attended Head Start, two elementary schools, a middle school, and part of high school before coming to Hope, where he had attended for the last 4 years. He received special education 
services for a learning disability. Zach reported that he was a friendly person but recognized that the characteristic had gotten him in trouble at school. He had come to Hope Academy by choice but acknowledged that his behavior at public school might have gotten him expelled if he had not left the school. He lived with his mother, and they had been homeless for several months at the time of the first interview. During the second interview, Zach stated that they had moved out of a hotel and into a house, and that his mother was very happy. He had been arrested about a year before the interviews, which he stated would be his first and last court involvement. Zach cited his older brother, who had dropped out of high school and did drugs, as someone he did not want to be like. Zach's home high school, Adams High, was located in a small urban community neighboring the one in which Hope was located. It enrolled over 1,100 students, $60 \%$ of whom qualified as low-income students. Forty-six percent of students were Caucasian and 35\% were African American.

Zach participated in three interviews. He was the most talkative of all the participants, and he was eager to share his experiences with me. His interviews ranged in length from 16 minutes 34 seconds to 1 hour 9 minutes 22 seconds. He often discussed topics that were peripherally related to my questions and his responses were rich with examples, personal information, and strong feelings.

Luke. Luke was a Caucasian senior who was 17 years old. He had attended three elementary schools, all in the same community, before attending one middle and one high school. He had come to Hope during his junior year and had been there for approximately one year. Luke's interests included playing any sports, particularly football and bowling, and rooting for the Patriots. He was a student with a learning disability and had 
moved to Hope primarily because of attendance concerns.

Luke attended West High prior to his enrollment in Hope. West High was located in the same small urban community as Hope Academy. West High enrolled approximately 1,400 students of whom 54\% were Caucasian, $32 \%$ were African American, and $35 \%$ were low income.

I interviewed Luke three times; these interviews ranged in time from 13 minutes 42 seconds to 34 minutes 12 seconds. While he was always willing to talk with me, Luke was not particularly interested in the interview process nor in being especially introspective. Luke was often tired during interviews, informed me that he needed naps, and lost his place on topics while he was speaking or thinking about answers. The lengths of Luke's interviews were deceptive, as he sat often silently, thinking about his responses, sometimes asking me to repeat questions or explain what I meant. He never refused to answer questions, but he did occasionally decline to explain further some of his one-word responses.

Isaiah. Isaiah also attended West High prior to enrolling in Hope. He had been home schooled during his elementary years and attended two elementary schools, one middle school, and West High for 21/2 years before coming to Hope. He was a junior, 16 years old, and African American. Isaiah had been at Hope for only 3 days at the time of his first interview. He liked to play music and basketball and hang out with his friends. Isaiah was involved with the juvenile court because of an arrest at West High. This same incident, the nature of which he declined to share, was the cause of his expulsion from West. 
Since Isaiah had been at Hope for only 3 days at the time of our first interview, he was initially somewhat unsure of the interview process as well as of his new school. Isaiah participated in three interviews ranging in length from 12 minutes 11 seconds to 22 minutes 29 seconds. During the second and third interviews, Isaiah was more comfortable and shared more information with me. It was easy to establish rapport with him, and he was very polite. He was physically active during all interviews, tapping the table, fidgeting, or chewing on a straw. Isaiah informed me that sometimes he had difficulty sitting still and paying attention at school.

Hailey. Hailey also attended West High before Hope. She had attended two elementary schools, two middle schools, and West prior to coming to Hope, where she had attended for approximately half of a school year. Hailey was a 16-year-old African American junior with a learning disability and had been expelled from West for threatening a teacher. She had six siblings, one of whom also attended Hope. Hailey likes to hang out with friends, but she more often stays home, playing Wii with her sisters.

Hailey's three interviews ranged in length from 15 minutes 33 seconds to 29 minutes 43 seconds. She was shy but open and blunt about discussing her situation and feelings. Hailey talked softly but did become more animated when discussing situations that made her either very excited or upset. She frequently answered questions with one or two words, but when prompted, she expanded on her responses.

Andrea. Andrea was African American, a junior, and 16 years old at the time of her first interview. She had attended three elementary schools, one middle school, and one high school prior to being placed at Hope about 10 months before the first interview. Andrea had been expelled from East High School after hitting a teacher who tried to 
break up a fight between Andrea and another student. She is excited about having her work permit and looking for a summer job and enjoys spending time with her friends, playing volleyball, and go shopping.

East High was located in the same small urban community as West High and Hope Academy. East High enrolled approximately 1,260 students of whom 45\% were Caucasian, $41 \%$ were African American, and 50\% were low income.

I interviewed Andrea on three occasions. The interviews ranged from 10 minutes 49 seconds to 29 minutes 9 minutes in length. Andrea smiled often during her interviews, and we easily built rapport. She was frank about her experiences, although some of them confused her. She had a strong personality, always looked me in the eye, and was concerned that I really understood what she was trying to express.

\section{Data Collection}

After obtaining approval from the university's Institutional Review Board (IRB) to conduct this study, I collected the data needed to address the study's research questions from three sources. I reviewed school documents, conducted classroom observations at the regional safe school setting, and conducted personal interviews with each participant. I reviewed school documents describing the purpose of the school, the population of students served, and student outcomes. I conducted classroom observations prior to the interviews in order to lessen observer effects, to note teacher-student interactions, and to identify possible questions or probes to be included in the interview protocols.

\section{Generation of Document Data}

Prior to interaction with students at the alternative school included in this study, I reviewed school documents in the public domain to determine the school's mission. 
Hope Academy was a public school funded as part of the Regional Safe Schools

Program. These documents outlined the missions of the school, the academic and social programs offered by the school, and how the school addressed the needs of students with disabilities. I reviewed the school documents prior to site selection to determine from which sites participant selection would be appropriate since some Regional Safe Schools do not accept students with disabilities.

\section{Generation of Observation Data}

The second component of data collection was classroom observation. Observation involves the collection of data on a phenomenon in a natural setting (Creswell, 2007). While attempting to observe and produce representations of the world, observers also become part of it (Denzin \& Lincoln, 2003). The behavior of the subjects under study is influenced and changes in response to the presence of an observer (Bogdan \& Biklen, 2007; Bogdan \& Taylor, 1975; Shaffir \& Stebbins, 1991). Qualitative researchers must be aware of the fact that their presence may alter observed behavior and recognize that "objective reality can never be captured. We can know a thing only through its representations" (Denzin \& Lincoln, p. 8).

I conducted seven observations totaling approximately 4 hours across a variety of settings within the school that served as the research site. Student arrival and breakfast, lunch, earth science, English, art, and Spanish classes were included in my observations. Students with IEPs were present in all settings. I conducted the observations on 4 days.

I drew diagrams of the classrooms and took detailed anecdotal field notes during all observations. My notes described the settings, students and adults, lessons and activities, teacher-student interactions, and student-student interactions. My notes also 
contained my observer reflections and quotes to maintain the integrity of dialogue when possible. These classroom observations allowed me to observe the day-to-day functioning of students with disabilities in each of the school settings and their interactions with their peers and the adults in their classrooms.

\section{Generation of Interview Data}

The purpose of interviews is to "let the voices of our participants speak and carry the story through dialogue" (Creswell, 2007, p. 43). In qualitative research, interviews focus on gleaning rich information and description related to the research questions. They are semi-structured and generally informal, containing prepared questions and the opportunity for the researcher to probe beyond those questions (Berg, 2004; Mason, 1996). The essential function of qualitative interviews is to understand the meaning participants give to people, events, or structures in the world (Bogdan, \& Biklen, 2007; Bogdan \& Taylor, 1975; Warren \& Karner, 2010).

I developed a semi-structured interview protocol for the first round of interviews to explore student perspectives about their current regional safe school and home schools. After securing permission to contact the students' parents or legal guardians, I secured written permission forms from the parents and informed assent from the students. The parent permission and child informed assent forms detailed that student participation was voluntary, that participants could withdraw at any time, and that my dissertation advisor (Dr. Maureen Angell) and I would protect the confidentiality of the participants. The study's research questions, school document review, and classroom observations served as a guide for the construction of the interview protocol, and all interview questions used during the first round of interviews focused on exploring the specifics of student 
perspectives (See Appendix A for a copy of the initial interview protocol). I designed interview questions for subsequent interviews based on overall themes identified by the students as a group as well as individual student responses to interview questions. Consequently, for the second and third interviews, I developed some questions that I asked of all students and questions that I asked of individual students in order to delve further into their experiences. Appendix B contains questions for each of the second interviews with students, and Appendix C contains questions that I asked of students during the third interviews. I determined the number of interviews for each student by reviewing their interviews and determining when I had reached saturation for each.

I conducted the semi-structured interviews with the participating students at locations selected by the students and their parents; I conducted the majority of the interviews during noninstructional periods of the school day in a private room at the school. I conducted each interview in one-on-one format, with only the student and I present. I digitally audio recorded the interviews and transcribed them to guarantee accuracy. A colleague reviewed all transcripts and recordings to confirm the accuracy of transcription.

\section{Data Management and Analysis}

Mason (1996) wrote that, "it is more accurate to speak of generating data than collecting data" (p. 36). Data management and analysis allow researchers to generate the data and description of qualitative study. I used cross-case analysis (Miles \& Huberman, 1994) to identify themes in this study. This type of analysis deepened my understanding and explanations of phenomena and the experiences and perspectives of the participants. Stake (2006) noted that with cross-case analysis, researchers must attend to the issues of individual cases to ensure that the integrity of each case is maintained while also meshing 
the case into its role as part of the collective analysis. That respect for individual perspective, together with the generation of collective findings, was the objective of the analysis of this research.

“"Data analysis' refers to a process which entails an effort to formally identify themes and to construct hypotheses (ideas) as they are suggested by data and an attempt to demonstrate support for those themes and hypotheses" (Bogdan \& Taylor, 1975, p. 79). As with all qualitative study, data analysis in the current study began during data generation (Bogdan \& Taylor, 1975). As I reviewed documents, transcribed field notes, and transcribed, read, and coded interviews, themes began to emerge. Miles and Huberman (1994) described several features of data analysis including the following: coding notes, writing reflections in the margins, and identifying patterns and themes ( $\mathrm{p}$. 9). I completed these on an ongoing basis between data collection sessions, and incorporated the codes, reflections, and themes into later data collection sessions.

After I transcribed the interviews and field notes, I coded the transcripts line-byline. This coding allowed me to identify themes in individual interviews and codes for all the generated data and recognize themes that were present in the interviews of multiple participants. Through the analysis of codes, the perspectives of participants emerged in several distinctive themes.

My dissertation advisor independently coded all of the transcribed interviews lineby-line. We met as a team a number of times to discuss the codes and confirm that we had identified the same themes, that we had included all participant perspectives, and that we had discussed any disagreements we had about perspectives the data had illuminated. 
Through discussion, we came to consensus on the identification of emergent themes and categories.

\section{Confirmability}

Miles and Huberman (1994) defined confirmability as both the lack of biases of the researcher and the "explicitness about the biases that exist" (p. 278). The authors likened the confirmability of qualitative findings to the validity of results in quantitative studies. According to Mason (1996), data analysis that is honest, reflects participant perspectives, and is related to research questions increases the validity of findings. She identified two ways to demonstrate validity. Validity of data generation methods relates to the extent to which researchers describe and analyze the issues and ideas identified in the research questions. Validity of interpretation relates to the quality, rigor, and conclusions reached through data analysis (p. 154).

A number of methods may be used to achieve confirmability of a study's conclusions. I selected several confirmability methods for this study. The first of these was generating data from multiple sources. Although they advocated against using the term, Bogdan and Biklen (2007) defined triangulation as a way to verify facts through multiple sources of data, because many sources lead to a more comprehensive understanding of the case. In the current study, I generated data from three sources. I reviewed documents to establish general characteristics and mission of the setting, conducted observations to understand environmental factors, and conducted interviews to gain student perspectives about the phenomenon. The synthesis of data from these three sources provided confirmation of participant perspectives and strengthened the validity of the findings. 
Researchers have identified the gathering of feedback from informants (Miles \& Huberman, 1994; Shaffir \& Stebbins, 1991) as a way to enhance confirmability. Conducting respondent validation (Creswell, 2008), researchers ask participants to review findings for accuracy and to determine whether or not their viewpoints are reflected in the analysis. A related technique, member checking (Creswell, 2008; Stake, 1995), is a process whereby the researcher asks participants to review the study's findings specific to their input and check for "accuracy and palatability" (Stake, 1995, p. 115). In the current study, I presented participants with a summary of the study findings and asked them whether or not they thought their perspectives were reflected in the summary. In addition, I asked each of the 8 participants to review quotes that I attributed to them, and I requested their permission to include these quotes in the final report. Both respondent validation and member checking confirmed the findings of this study.

\section{Role of the Researcher}

"Even when empathic and respectful of each person's realities, the researcher decides what the case's own story is, or at least what will be included in the report. More will be pursued than was volunteered. Less will be reported than was learned" (Stake, 2003, p. 144). In qualitative studies, researchers must take particular care to examine their relationship to the setting and their feelings about the participants and research process. If researchers do not engage in this type of reflection, they will be unaware of how their perspectives affect the findings of the study (Kleinman, 1991).

As the primary researcher in this study, it was important for me to reflect on my role in the research. I have worked in the field of special education for 11 years. I spent my first 9 years as a special education teacher and the most recent 2 as a special 
education administrator. I am currently working in the same administrative capacity. In these roles, I have worked with many students who were at risk for multiple suspensions or expulsions, students who attended regional safe schools, and students returning to their home schools from regional safe schools. Based on this professional experience, I am familiar with the operation of the regional safe school (Hope Academy) that serves the school districts in which I have worked. I had no knowledge about the other alternative school before undertaking this study.

As part of the requirements of the doctoral program, I completed a qualitative study exploring the perspectives of students who attended therapeutic settings (deGruy, 2009). The 3 students who participated in the study had been removed from their home schools and placed in private therapeutic schools. They expressed opinions about the strengths and weaknesses of the two programs. The findings of my 2009 study were the basis of the current investigation, which extends the research to students in alternative, but not therapeutic, educational settings.

\section{Ethical Considerations}

I carefully attended to ethical considerations throughout this study. The research protocol (\#2010-0396) is on file and was approved by the university’s IRB. Letters of contact, informed consent and assent forms, and sample interview questions are included in the protocol. As part of this study, I held initial meetings with all the participants and their parents or legal guardians, if requested, to ensure their understanding of the purpose of the study, how data would be generated, and what the final product of the study would be. In addition, I informed the participants verbally and in writing that they could withdraw from the study at any time without penalty. During the informed assent 
process, I secured each participant's permission to digitally audio record participant responses to interview questions.

To protect their privacy, I assigned my participants to choose names by which they were identified during the study, in all notes, and in this publication. After completion of the data analysis, I gave the participants the opportunity to review a summary of the study's findings and their individual quotes that were part of the manuscript. All digital audio recordings and written data were kept in a locked cabinet in my home or on password-protected computers.

\section{Chapter Summary}

This chapter includes references to the literature on qualitative methodology in order to explain the research design of this study. I used collective case design and crosscase analysis in the study in order to better understand the perspectives of students with disabilities who attend alternative schools. This chapter also contains descriptions of my participants and my data generation and analysis methods. My use of qualitative methods, including the multiple sources of data and thorough data analysis, allowed me to generate and synthesize rich descriptions of student experiences, which I will report in Chapter IV. 


\section{CHAPTER IV}

\section{FINDINGS}

This chapter includes a report of the findings from data collected through documentation, observations, and interviews. The purpose of this study was to investigate the perspectives of students with disabilities who attend a regional safe school on their schooling experiences. The following research questions guided this study:

1. What are the perspectives of students enrolled in a regional safe school regarding their experiences in their home schools and regional safe school?

2. What are the perspectives of students enrolled in a regional safe school regarding strengths and weaknesses of the services and programming received at their home schools and regional safe school?

3. What are the perspectives of students regarding the effectiveness of their schooling in their home schools and regional safe school?

4. What do students identify as the key elements to their success in school, and what are their comparative perspectives on how their home school and regional safe school address those elements?

Although these were the questions established at the outset of this study, student responses to interview questions designed to answer Research Questions 1 and 3 were the same. Students answered questions according to the way they defined their overall perspectives and effectiveness, which were both related to their perceptions of success. For the purposes of Chapters IV and V, I have combined Research Questions 1 and 3 in order to share students' voices and interpretations. I further explain and discuss this with the interview findings. 


\section{Results of Documents Review}

The principal of Hope Academy provided documents that outlined the mission, programs, and student data of the school. Initially, I used these documents to ensure that Hope Academy would be an appropriate school from which to recruit students for this study. After establishing that fact, I used the documents to confirm information provided by participants. These included the Regional Office of Education's (ROE's) website, the school's website, the student handbook, the building master schedule, and the FY 2010 End Year Report. I have described and outlined how I used each of the documents to confirm my interview data.

\section{Websites}

The ROE website outlined the purpose of Hope Academy as serving students who had been multiply suspended or expelled in accordance with the Safe Schools Act. It also contained contact information, courses available, community agencies with which the school worked, and service learning opportunities. The Hope Academy website contained a listing of high school and middle school courses, contact information for individual staff members, downloadable student handbook and registration forms, and links to the home school districts with which Hope worked. Both websites clearly stated the mission and purpose of Hope Academy and provided information to parents and visitors about school offerings and community connections.

\section{Student Handbook}

The principal provided me with the student handbook, which is given to students and their parents when the students register at Hope Academy. The handbook provided the mission statement of the school, the school calendar, and school policies and 
regulations on a variety of topics. In addition, the handbook contained the Student Code of Conduct, which described the student success card and level system, school-wide expectations, special education information, and consequences for inappropriate behavior. The information contained in the handbook was used to confirm information offered by students about the general expectations, level system, and purpose of Hope.

\section{Master Schedule}

The master schedule contained information about the courses offered each hour by each teacher. When the principal gave me the master schedule, she pointed out that there were some teachers who were employed only half time. She informed me that the school's teachers are not unionized and that employment from year to year is based on student enrollment and need. The master schedule listed all courses that were named as

offerings on the website as well as additional coursework that was available to students. I was able to use the master schedule to ensure that I observed in the classrooms of both general and special education teachers.

\section{FY 2010 End Year Report}

The Hope Academy FY 2010 End Year Report provided demographic information about the students who attended Hope during the 2009-2010 school year. It included information about how many students attended Hope, the students' race/ethnicity, whether they were placed as the result of multiple suspension or expellable behavior, and academic outcomes for the students. Because of the ever-changing student population at Hope, the statistics listed in the End Year Report were reported as part of this study. According to the report, approximately $34 \%$ of the students who attended Hope were expulsion-eligible, while $66 \%$ had been multiply suspended. I used this information to 
confirm students' perceptions about their own placement at Hope Academy as well as their perceptions of their peers.

\section{Findings from Observations}

I conducted observations at Hope Academy on 4 days. I observed a number of settings within the school including student arrival and breakfast, lunch, and earth science, English, art, and Spanish classes. I also noted student behavior in the hallways on a number of occasions other than the 4 observation days. I took detailed field notes during each observation and included diagrams of classroom and common area settings. I wrote down quotes when possible to capture the interactions of individuals in the setting. Table 4 contains information about each of the observations. Through the analysis of my notes, I identified the following themes: (a) the expectations in the environment were clear and generally followed, (b) the environment and teaching styles demonstrated were student centered, and (c) there was evidence of strong student-teacher relationships. 
Table 3

Observations

\begin{tabular}{|c|c|c|c|c|c|c|}
\hline Class & $\begin{array}{l}\text { Date and } \\
\text { Time }\end{array}$ & $\begin{array}{l}\text { Number } \\
\text { of } \\
\text { Students }\end{array}$ & Gender & Ethnicity & Format & Decor \\
\hline $\begin{array}{l}\text { Student } \\
\text { arrival }\end{array}$ & $\begin{array}{l}11 / 18 / 2010 \\
8: 10-8: 30\end{array}$ & 36 & $\begin{array}{l}\text { Not } \\
\text { recorded }\end{array}$ & $\begin{array}{l}\text { Not } \\
\text { recorded }\end{array}$ & Unstructured & $\begin{array}{l}\text { Café tables: } \\
18 \text { total; } 12 \\
\text { have } \\
\text { students and } \\
\text { staff }\end{array}$ \\
\hline $\begin{array}{l}\text { Earth } \\
\text { science }\end{array}$ & $\begin{array}{l}\text { 11/18/2010, } \\
8: 35-9: 25\end{array}$ & 7 & All male & $\begin{array}{l}3 \\
\text { Caucasian, } \\
3 \text { African } \\
\text { American, } \\
1 \text { Hispanic }\end{array}$ & $\begin{array}{l}\text { Lecture, } \\
\text { discussion, } \\
\text { independent } \\
\text { work }\end{array}$ & $\begin{array}{l}\text { Large } \\
\text { arched } \\
\text { windows, } \\
\text { sci-ence } \\
\text { posters, } \\
\text { shadow } \\
\text { boxes of } \\
\text { specimens, } \\
\text { displayed } \\
\text { artifacts, } \\
\text { tables }\end{array}$ \\
\hline $\begin{array}{l}\text { English } \\
(9 / 10)\end{array}$ & $\begin{array}{l}\text { 11/19/2010, } \\
9: 21-10: 15\end{array}$ & 15 & $\begin{array}{l}9 \text { male, } 6 \\
\text { female (1 } \\
\text { pregnant) }\end{array}$ & $\begin{array}{l}1 \\
\text { Caucasian, } \\
13 \text { African } \\
\text { American, } \\
1 \text { Hispanic }\end{array}$ & $\begin{array}{l}\text { Lecture, } \\
\text { discussion, } \\
\text { review, } \\
\text { testing, read } \\
\text { aloud }\end{array}$ & $\begin{array}{l}\text { Large } \\
\text { arched } \\
\text { windows, } \\
\text { motivational } \\
\text { posters, } \\
\text { student } \\
\text { work, tables } \\
\text { and desks }\end{array}$ \\
\hline Lunch & $\begin{array}{l}11 / 22 / 2010 \\
11: 05- \\
11: 35\end{array}$ & 27 & $\begin{array}{l}\text { Not } \\
\text { recorded }\end{array}$ & $\begin{array}{l}\text { Not } \\
\text { recorded }\end{array}$ & Unstructured & $\begin{array}{l}\text { Café tables: } \\
18 \text { total; } 12 \\
\text { have } \\
\text { students and } \\
\text { staff }\end{array}$ \\
\hline $\begin{array}{l}\text { English } \\
(11 / 12)\end{array}$ & $\begin{array}{l}11 / 23 / 2010 \\
9: 25-10: 00\end{array}$ & 6 & $\begin{array}{l}5 \text { male, } 1 \\
\text { female }\end{array}$ & $\begin{array}{l}2 \\
\text { Caucasian, } \\
4 \text { African } \\
\text { American }\end{array}$ & $\begin{array}{l}\text { Review, } \\
\text { discussion, } \\
\text { read aloud, } \\
\text { independent } \\
\text { work }\end{array}$ & $\begin{array}{l}\text { Large } \\
\text { arched } \\
\text { windows, } \\
\text { inspirational } \\
\text { posters, } \\
\text { Smart }\end{array}$ \\
\hline
\end{tabular}


Board, 11

desks in 4

rows

\begin{tabular}{|c|c|c|c|c|c|c|}
\hline Art & $\begin{array}{l}11 / 23 / 2010 \\
10: 50- \\
11: 15\end{array}$ & 6 & $\begin{array}{l}4 \text { male, } 2 \\
\text { female }\end{array}$ & $\begin{array}{l}2 \\
\text { Caucasian, } \\
4 \text { African } \\
\text { American }\end{array}$ & $\begin{array}{l}\text { Independent } \\
\text { activities: } \\
\text { cutting } \\
\text { stencils, } \\
\text { drawing, } \\
\text { working } \\
\text { with plastic } \\
\text { pixels }\end{array}$ & $\begin{array}{l}\text { Large } \\
\text { arched } \\
\text { windows, } \\
\text { art timeline, } \\
\text { stu-dent } \\
\text { work, kiln, } \\
\text { washer, } \\
\text { dryer, } \\
\text { kitchen-ette, } \\
\text { large work } \\
\text { tables }\end{array}$ \\
\hline Spanish & $\begin{array}{l}\text { 11/23/2010, } \\
11: 30- \\
12: 00\end{array}$ & 9 & $\begin{array}{l}5 \text { male, } 4 \\
\text { female }\end{array}$ & $\begin{array}{l}2 \\
\text { Caucasian, } \\
7 \text { African } \\
\text { American }\end{array}$ & $\begin{array}{l}\text { Review, } \\
\text { discussion, } \\
\text { notebook } \\
\text { checks, } \\
\text { movie }\end{array}$ & $\begin{array}{l}\text { Large } \\
\text { arched } \\
\text { windows, } \\
\text { inspirational } \\
\text { posters, } \\
\text { Smart } \\
\text { Board, } 11 \\
\text { desks in } 4 \\
\text { rows }\end{array}$ \\
\hline
\end{tabular}

\section{Clear Expectations}

Clear expectations for student behavior were evident immediately in my observations at Hope Academy. During my first observation, I was present for student arrival. Students arrived in the building, staff searched students and their belongings, and students proceeded to breakfast. All students complied with the search; only one student complained. When the bell rang to begin the day, the principal addressed the silent group of students with several announcements and all stood to recite the Pledge of Allegiance. She reminded them that they are to catch the bus and not loiter after school. When I asked her about whether there had been problems after school, she replied that she touched on one all-school expectation every morning during the announcements. 
Students proceed directly to class; there are no scheduled passing times, so the expectation is that students do not linger in the hallways. During lunch, students form an orderly line to retrieve their food and punch their lunch codes into a number pad. The atmosphere is relaxed, but expectations continue to be evident. Students remain seated unless they are throwing away garbage or using the microwave ovens to warm their food.

Consistent expectations were also evident in academic settings. During the earth science class, the students follow an established routine. Each student enters the class, retrieves his folder from a specific bin, and begins the warm-up activity that is on the overhead projector. I witnessed in this class, as I did in others, a student approaching the teacher with a bathroom pass for her to sign. A student later told me that students receive a specified number of passes for the quarter; when the passes are gone, the student can take a detention if he needs to leave.

All classrooms are clean and well organized with labeled cabinets and bins, and the school expectations are posted. In addition, each class follows the building expectations and has expectations that are specifically related to the teacher or academic subject. One of these is the "To-Dos for To-Day" that an English teacher posts. It contains four short, explicit statements to students. The first two have to do with the assignment contents and due dates; the last two read, "I am not helping you on these. Do your best." and "You will be fine. I promise." No students in this classroom required redirection to do their work or because of behavior. At the conclusion of every class session, students need to present their point sheets to the teacher so that the teacher can complete them. During my observations, every student presented this card to the teacher and none argued with the teacher's ratings of student behavior. Expectations had clearly been taught since 
there were no classroom disruptions and only four students were off task during my observations. Expectations for the way students treat each other were also clear. When one student laughed at another's question in science, the teacher redirected, "We never laugh at people who are trying to make themselves better."

\section{Student-Centered Environment}

Classes at Hope were taught in a manner that was student-centered and responsive to the needs of individual students. In a freshman/sophomore English class, the teacher gave multiple verbal prompts, warning students of the transition between activities:

"You have 7 minutes to get ready for your vocabulary test" and "in 30 seconds we're going to begin the test, so let's take everything off our desks." This was an experienced special education teacher who likely knew that her students would have difficulty with the transitions. She also gave a single direction, waited for the class to follow that direction, and then proceeded with additional directions in the same manner.

In another English class, the teacher asked the students whether they understood the novel better when they read silently or when they listened to the recording of the book. All students agreed that they liked listening to the recording and following along in the book better because they could understand more when they got to see it and hear it. There was also an emphasis on individual student strengths in art class. As students were working on various projects, several students complimented one on the quality of his work. The teacher praised the effort of the whole group, noting that they would do many activities during the class so that everyone has the chance to show his or her strengths.

The curriculum and instructional materials were student centered. In both English classes, the group read novels containing themes to which students could relate. One was 
about a student who committed suicide after being bullied and the other about a teenage courier who didn't know what he was carrying, only that his mother needed his money for rent. Both elicited spirited participation from all students in the classes. Discussions related to the novels as well as to the lives of the students; much was said about how our actions affect others, either positively or negatively. Literary elements and social skills lessons were taught in a personal way. In a Spanish class, the class prepared to watch a movie, talking about gender roles in the United States and in their families. They were told to be prepared to discuss how the cultural beliefs in the movie compared and contrasted with those of their families.

In earth science, there may have been less opportunity to link with the personal experiences of students; however, the teacher made the class student centered in a number of ways. She linked new concepts through discussion and graphic representation to concepts that the class had already learned. Students asked many questions, indicating that this classroom was clearly a place where students could take academic risks. The teacher's classroom was vibrant, appealing to visual learners. There were posters on the walls and shadow boxes containing insects and spiders; the deep window ledges, which run the length of the classroom, were home to artifacts, rocks, and bones. Students handled these items throughout the class period, and some discussion centered on the origin of the objects.

Last, the student-centered environment was evident in the way that teachers interacted with students. All of the students at Hope attended the school as a result of multiple suspensions or expulsion, but behavior disruptions during classes at Hope were a rare occurrence. Teachers ignored low-level behaviors, even those that may have been 
specifically intended to provoke them. Students talked to themselves while they worked, stood at or tapped on their desks, and sat with entire desks on their laps, but teachers continued teaching. Students made statements directed at teachers or to the room in general like, "You bogus" or "I don't even care about this test," and teachers did not respond to the statements, either ignoring them or redirecting students to alternate activities. On three occasions, I witnessed teachers step into the hallway with students to address issues privately.

My observation of the lunch period was especially striking. Students and staff members ate lunch together at café-style tables, and all were involved in conversation together. When I asked the principal about this later, she told me that she offered her staff the opportunity to trade their duty-free lunch time for the time that they are required to stay after school. Students and adults eating together had become part of the building culture. Two students approached me to ask what I was doing there and let me know that I could eat with them if liked. When I explained my project to one of the students, he said, "I'm a senior. I'm not ready to leave, 'cause I love this school."

\section{Strong Student-Teacher Relationships}

Strong student-teacher relationships were evident across settings at Hope Academy. In every class I observed, teachers greeted students as they came into the classrooms, making personal comments to many students. I heard, "Looking good this morning," "Glad to see you here early," and "You look really nice today." Teachers and other staff members interacted with students in a caring and respectful manner and expected the same from students. 
In the Junior/Senior English class, all students participated in the discussion. During the class, a student came to the door, presumably from another class, to ask the teacher for some help with an assignment for another class. The teacher replied that she had a class, but that she would make time to meet with the student later in the day. The teacher had an easy banter with the students and encouraged them toward success: "I will give you something hard so you can rise to the occasion...I know, it's horrible, but you'll survive." They talked about severe allergies to work and paper cuts that could harm them. While students worked independently, she circulated around the room, wished one a happy birthday and gave him a card, answered questions, and checked in with each student on his or her progress. At the end of the class, when one student asked if the class could watch a movie for Thanksgiving, she smiled, responding, "You should just be thankful that I'm here." The class groaned and laughed.

The art teacher sat with the students at the large work table, engaging in art activities with them. When one student became agitated because he was unable to iron his pixel design, the teacher said, "Do you have it turned on? Is it plugged in? That's probably where I would start to problem solve." The student found the iron unplugged, and the situation was quickly resolved. Later, when a student insulted another, the teacher redirected them, saying, "Guys, I need some help here. I'm trying to fade the color in my design, and I need to know what you think." Both students responded, stopping their conversation and moving to focus on the art teacher's design. At the end of the class, the teacher requested that the students help clean up the room. One began to argue about not having made the mess. The teacher responded, "I'm sorry, that's not an accusation. I'm not saying you did it; I'm just asking for your help." This teacher was 
able to defuse a number of potential crisis situations in a short period of time, where dangerous objects were present, by relying on his relationship with students.

In a Spanish class, the teacher addressed all of her students as sir or ma'am, and every student participated throughout the class session. For the 30 minutes that I was present, nine sets of eyes tracked her every dynamic move. The teacher demonstrated her relationship with students in a number of ways. She managed behavior by walking by a student rocking in his chair and placing her hand on his shoulder while she continued to teach. She checked the work of all students and verbally reinforced them in both Spanish and English. Students ask her when she would take them to a Mexican restaurant for lunch, and she replied, "Not soon enough, right?"

As I stated previously, the lunch period that I observed was quite striking. Twenty-seven students and 10 adults ate together, discussing their weekends and Thanksgiving plans. Only one table of students was without adults, and one student sat alone at a table, reading a book. One student sat by himself in a chair along the wall. Three adults approached and talked to him during the period, but he did not respond. A teacher later reported to me that this was his third day at Hope, and he was boycotting lunch because he thought he should be able to leave school for lunch, as he did in public school.

Breakfast was also a time during which students and adults socialized. A teacher cooked and served homemade eggs and sausage, greeting students as he handed them their plates. At this meal, 12 tables were occupied; students and staff sat around eight of the tables. Adults asked students how their night went and how their morning had gone thus far. During morning announcements, the principal reminded students to dress for 
the weather as she did not want them to be cold and get sick while waiting for the bus. At both breakfast and lunch times, adults and students shared meals and conversation in a more intimate environment than I have witnessed in public school settings.

All students were respectful to each other and the teacher in their earth science class. Students asked questions during the lesson but did not speak while the teacher was speaking. The teacher wrote notes and walked around the room, checking on each student as he wrote the notes. She had individual conversations with many of them. One student did not have his note taking materials out, and she retrieved them for him, placing a sheet of paper on his desk and writing the heading on the top of his paper. When she circulated back to him again, he was still not taking notes, and she quietly asked him to step into the hallway and speak with her. He did so without argument and returned to take the notes. After group work was completed, one student asked the teacher about his grade, saying that he had to get it up to a C. She helped him locate some work, and he said he would do it at home. She replied, "Start it now. Go ahead and start it now." The student did not want to do the work, but she sat next to him, explaining how the assignment was to be done, and they began it together before the end of the class session. In the freshman/sophomore English class, the easy banter between the teacher and students indicated their strong relationships. The teacher greeted the students as they entered, telling several of them that they looked nice or that she was glad to see them. The teacher passed out grade sheets to students and one groaned when she saw her grade. The teacher said, "You know what would help that? Attendance - all day, every day." The student replied, "Girl, nah," and the teacher responded, "Girl, yeah." Later, during independent work time, the teacher walked around the classroom, checking on the 
students as they worked. One student was not doing the work, and the teacher said, "Shoot, invisible ink! Let me get you a pen." She retrieved a pen for him and tried it out by writing his name at the top of the paper. He worked for the remainder of the class.

\section{Findings from Interviews}

\section{Concept Map of Interview Findings}

Concept maps are visual representations of the relationships between emergent themes and possible conclusions to be drawn from the findings of qualitative research (Miles \& Huberman, 1994). Figure 1 illustrates the findings of this study and serves as a visual outline for the exploration of interview data.

At the center of the map are the perspectives of students at a Regional Safe School. Students identified several factors that affected their perspectives and contributed to their levels of success in school, and these factors are categorized in two broad themes: teachers and schools. Among the cited factors related to teachers, students identified characteristics associated with teachers' dispositions, knowledge, and skills. The factors related to disposition were understanding, caring, accessibility, and interest in students' lives outside of school. The factors related to knowledge and skills were explaining things well and following up. The school factors were associated with structure and culture. Those related to structure were small class sizes and clear student

limitations; those related to culture were family environment, student accountability, and motivation systems.

While teacher and school factors affect student perspectives about their educational experiences, those factors also contribute to identifiable changes in the students. 
Those changes, self-identified increases in motivation, self-awareness, and determination to succeed, are represented at the base of the concept map.

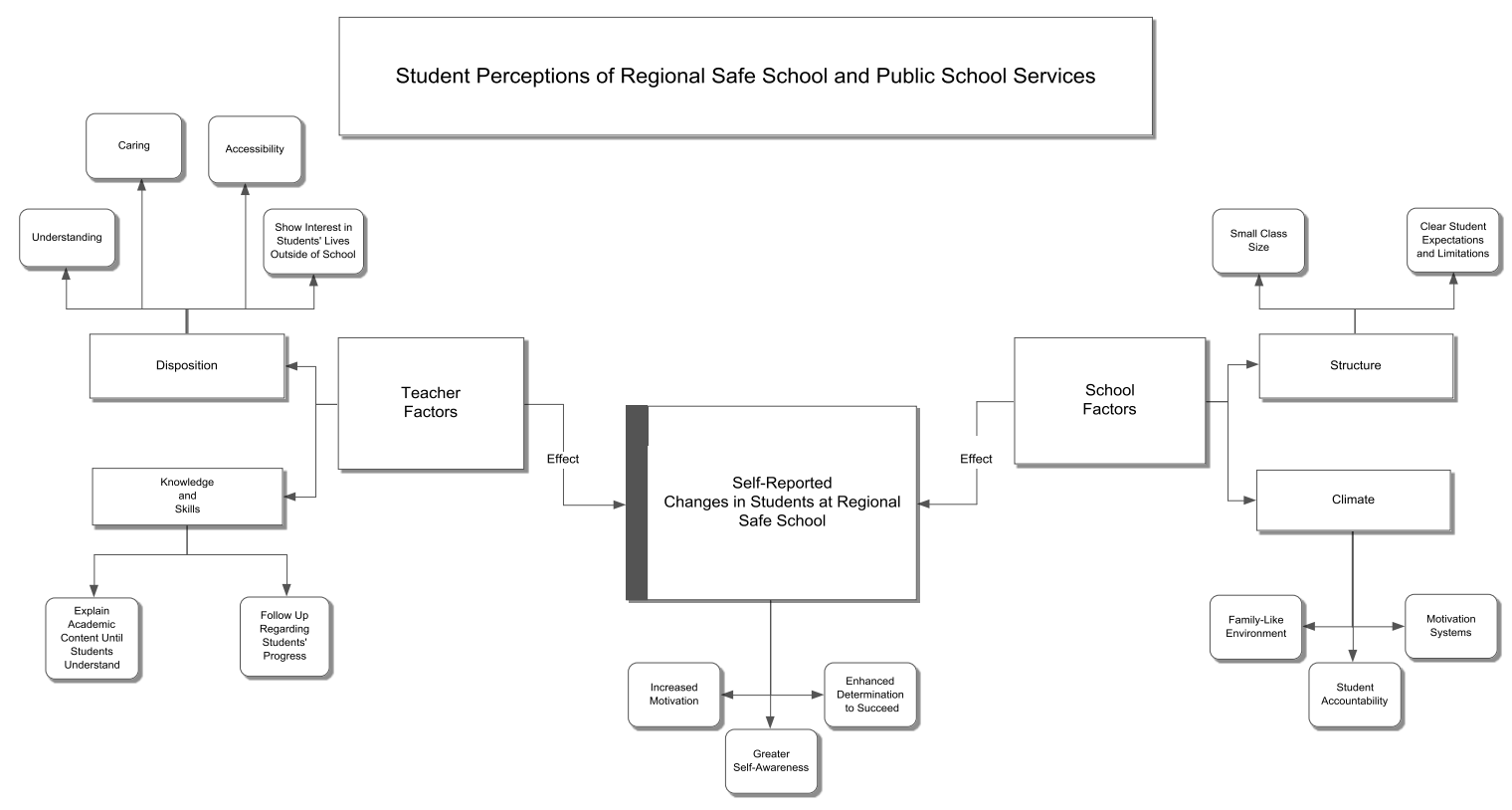

Figure 1. Concept map of major findings and themes.

\section{Teacher Factors: Disposition}

Understanding. Students who participated in this study believed that their

teachers at Hope Academy understood them; this was not always the case at their public schools. Some of these understandings were because of similar backgrounds, but some of the understanding came from students' feelings that teachers listened to them when they needed support.

I think here it's better 'cause the teachers are cool with students and stuff, and they know how to deal with drama and stuff. At Gable the teachers just want to send them out real quick in a hurry and they don't know what is going on and stuff like that. At Gable, when I got expelled I was having a bad day and the teacher had said something smart to me and I threatened her. But here when I'm having a bad day teachers leave me alone to calm down, and then they ask what's wrong. (Hailey, November 23, 2011) 
I think she understands me more. Through what I'm having problems with, like in work and school. I just think she understands me because she listens to me when I need to talk about stuff. (Luke, January 4, 2011)

It's like, they let me know that it's OK to, you know, it's OK to express your problems and what you're going through, because nine times out of 10 they have something or someone that they know can help you. (Zach, January 4, 2011)

Hailey also stated that she did not have a good contact person with whom she could talk during her current transition to public school, but that if she had problems, she would bring them back and talk to Hope staff about them. The fact that Hailey was in the process of transitioning back to her public high school at the time of this study indicated the level of success that she had achieved at Hope after having been expelled from public school during the prior school year. Andrea indicated that she felt understanding from one of her teachers, whom she describes as her favorite teacher, at public school.

She related to me and she helped me out with my problems, and she would try to help me and motivate me to keep going. (Andrea, January 20, 2011)

Bobby, who is from the same town as one of his teachers at Hope, felt that she probably understood him better because of that. He stated on more than one occasion that she had been like a mom to him, as his own mother was not in his life. She had also paid the fee for him to take driver's education. Bobby expressed that his football coach at his public school had offered to pay his athletic fee as well if it could not be waived. Both teachers had a good understanding of the familial and financial situation in which Bobby lived.

Hailey credited her improvements as a student to the teachers at Hope Academy. Their understanding and tolerance enabled her to get better grades and be more account- 
able for her grades and behavior. She noted that they were more laid back, goofier, and funnier than teachers at Gable, but that they also just understand students better.

Because the teachers don't act like the teachers at Gable. These teachers here are way, way better. They are-like-calmer, and they understand how our attitudes and stuff are. Because-like-oh it's hard to explain. But um, they'll just sit there and laugh. They won't say nothing smart to you, really. And if they ask you to do something, they'll just-like-keep asking you. They won't just send you outlike-the first time that you don't do it or whatever. And if, they'll be-like-if you don't to it then it's on you-like-it's on your card or your grade or whatever.

Better relationships with us and they understand better. (Hailey, January 5, 2011)

Caring. Participants in this study distinguished between teachers who cared

about them and teachers who were there because it was their job. Thomas reported that teachers and their attitudes were the most difficult part of public school. All of the students I interviewed discussed the importance of having teachers who care and talked about the effect that had on their willingness to attend school, participate in class and complete work, and the way the students felt about themselves.

If they care about you being successful, they're going to help you. Like-if teachers don't care, they don't really care if you don't be successful. They're not going to try as hard to teach you and make you learn and stay on you-like that and stuff. So it is really a big factor of success. (Isaiah, January 10, 2011)

Because it's-like-when a teacher, when they really don't care, you can tell. Like-say I had a Spanish teacher, and I couldn't get Spanish-like-that, it was kinda harder for me, and I asked for help, you can tell-like-if they really want to help you or if they help you and they got an attitude like they're trying to hurry up and help you with it. I think they really didn't have patience at Central. (Andrea, January 20, 2011)

I started thinking, well if they don't care, then I don't care. So I started thinking to myself harder about it-like-if a teacher doesn't care about a student, what makes you think that the student is going to care about themselves, because the teacher is projecting that image or giving you that light that you need to succeed. (Zach, January 25, 2011) 
At public school, the students' experiences varied, but few shared positive interactions that highlighted caring teachers. Bobby had bonded with one of his coaches and could name a solid relationship that he had with a teacher in middle school. Andrea had a teacher to whom she felt like she could talk, and Luke had a teacher whose class he liked because the work was easy. Evan talked about a teacher who was nice, and Zach described a teacher with whom he built a relationship after she read his poetry.

She was-like-this is actually good, though. She was-like-astounded by it, and I was like, wow, you know. So I built that bond with her through my feelings, because she actually-you know-read and took the time to read and understood. You know, she knew exactly how I was feeling, what I was going through, and she looked at me as more than what I've been through, she looked at me as who I'm trying to become. And I thanked her for that. (Zach, January 4, 2011)

Some students had determined that the teachers did not care about them, and some said that teachers cared about them but had stopped caring when the students themselves did not care.

They just don't care, some teachers don't care. They'll single you out 'cause they get frustrated. (Andrea, November 22, 2010)

People on football teams, basketball teams, baseball teams, track, all that, treated them totally different. Totally different. At Wright, if you ain't in a sport, you shouldn't even be at the school. (Thomas, November 22, 2010)

(At Gable) They would push me, but I wouldn't want to be pushed, because I know they really didn't care if did the work anyway. They would just tell me to do my work; they would walk away, and I just wouldn't do my work. (Luke, January18, 2011)

I think at Gable, they maybe showed it to me, but I didn't accept it. Like it was me that didn't accept it. Like I was the one, like I was just not trying to do work basically. So then they stopped, cause I just wanted like a free ticket basically, put it like that. (Isaiah, January 10, 2010) 
Some students made a clear contrast between their experiences with teachers in public school and those at Hope discussing the differences in the way they thought teachers felt about them. Evan agreed with Ryan about the differential treatment of athletes by teachers at their public school.

They just pay attention to what you need here, and at Wright they don't care, they have a job, to teach this and get paid. That's all they care about. At Wright if you are a football player all the teachers love you, like automatically. Here, it's like once you start here, you are loved. It's like, oh, you're the new kid? Well hi, I'm this teacher; hi, I'm that teacher. It's like constant, trying to be friendly and make friends with their students, and at Wright, it's like, are you going to play football? Well, whatever, go. If you aren't going to play football there or do their sports that they want you to do, you are nothing to them. You just don't matter. You are just another student. (Evan, November 19, 2010)

I can tell, I can-like-talk to them and know they aren't going to go around telling, gossiping. They keep it to their self, they help me when I need help, and I can go to them and tell them, "I, oh, I think I'm going to get into arguing," and they'll have me sit out of something if I need to so I don't get into no argument. (At East) I could tell a teacher, I told my dean and she just said don't argue. (Andrea, November 22, 2010)

Like if I need to talk to them I can talk to them, but at Wright I couldn't. (Thomas, November 22, 2010)

Probably just because the teachers here care more. They care more about the kids. I think they have better relationships, cause anybody-like-any student at this school can go to anybody-like-any teacher in this school, to talk to them. And they will help solve the problem, whatever. People at Gable wouldn't. Like-the teachers at Gable they would just brush them off and say I got to do something, or something like that. (Hailey, November 23, 2010)

Like-none of the teachers there are like friendly or anything, they're all-like-we come here, we do our job, we come home. Here it's-like-it's actually like they're motivated to do their job for some reason. I have no clue why, but we're just a bunch of bad children that get sent here, but they're motivated to teach us here and stuff, so it's-like-kids actually want to come here because they're motivated instead of just the teachers just slouching around and doing lame stuff like that. (Evan, January 10, 2011) 
They've actually got teachers who care. (At Mitchell) I hated all my teachers. And my teachers all hated me. Because they were just mean. Because I was a snobby little brat. And I never did my homework. (Bobby, January 25, 2011)

Students were unanimous in their belief that the teachers at Hope Academy were concerned with them as students and as people. As Evan stated, the participants recognized that they may not be the easiest students to teach, but the teachers at Hope were kind to and cared about them anyway. Bobby reported that he knew one of his teachers cared about him because she had told him that she did. There was an expectation of mutual respect and caring, set forth in the code of conduct, which pervaded adult-student interactions at Hope, and students trusted the adults at the school.

If we have trouble doing anything-like-trouble at home, trouble here, anything that's gone wrong, you can talk to anyone about it, and they can kind of help you guide through all that. (Luke, November 23, 2010)

I've seen-like-some really nice, great people. They just seem like they are friendly, like they really care, and they want to help. I see here that some of the classes I'm in, that students relate to teachers at a better level. (Isaiah, December 6, 2010)

My relationships here are solid. It's solid. It's-like- um, how can I say this. It's-like-they're dependable, you can depend on them. It's-like-it's like a relationship that you have with your best friend or with a close family member. That's the relationship I have with the teachers at Hope. (Zach, December 10, 2010)

It's not like, they'd be like, well he's not going to go anywhere. They actually think high of every last student who doesn't feel like they think, think high of themselves. If you feel bad about yourself, they think of you-like-you know, he's going to go somewhere. I'm going to make it my job to make sure that he goes somewhere, because I don't want to see him like this. They actually take the time out of their lives and stop what they're doing, which is an optional thing they could have did. They didn't have to do it. They chose to because the simple fact is they care what happens to us, and that's why I like this school so much, because they care. It's-like-it's not just school and business. They actually-you know-put their feelings into the work, and so do I, and then we just click. (Zach, January 4, 2011) 
I mean they let you know that whatever's going on, you can tell them, and they won't- like-if it's about somebody, they won't give your name, they'll just, you know, this person needs to stop or you need to stop doing this to that person, and pretty much-like-nice about it. (Bobby, January 7, 2011)

I respect them so they respect me. Like-they help me more with the work, stay on me about it-like-constantly every day, nag you. Like-the teachers they're friendlier here. It seems like they're friendlier. They help you, and they play a lot, kinda but not really. They're just nice, put it that way. (Isaiah, January 10, 2011)

They actually want to help you. They actually are determined to help you. They will not let you fail. They will not let you get a bad grade. It's-like-if you're having problems with something, and you're just-like-whatever-I don't want to do that and fly it off the desk or whatever, (the teacher) or somebody's going to come pick it up and they're going to set it in front of you and they're going to sit there and tell you they're not going to move until it's done. (Evan, January 10, 2011)

She motivates me. She keeps me positive. She helps me out with grades. If I have to stay after school, I can stay with her, stuff like that. She's real concerned. She helps you with anything you need, and if she can't get it, she'll help you find it. We'll look on the internet and see how to do it, and she'll ask another teacher, or she'll get together with another teacher to help you. So you can get the work and understand it. (Andrea, January 20, 2011)

The students may not have felt toward teachers at their public schools the trust they expressed in their teachers at Hope Academy. Not all students discussed this issue, but several discussed favoritism by their public school teachers. Thomas, Andrea, Evan, Zach, and Hailey indicated that teachers showed favoritism in the way they applied the rules; some students would get in trouble for exhibiting certain behaviors while others would not.

Once I got to high school, I just got detentions every day. I told them I can't deal with that. I need to leave this school. 'Cause you're not going to give me detentions for chewing gum when the school's allowed to chew gum. (Thomas, November 22, 2010) 
Some people actually don't want to hear the sides of the story. They feel like they can-um-like-some teachers might trust a certain side. Not saying that the teacher is choosing sides, but they might feel like, well, this story is more conclusive than that story, so we're not really going to pay attention to that story, we're just going to, you know, start displaying, you know, punishment. (Zach, January 4, 2011)

Uh-like-I would have my phone out, and the teacher would take mine, but another student had their phone out, and they'll tell them just to put it up. Like-sometimes they only follow the rules when they want. (Hailey, January 20, 2011)

Thomas talked about not trusting the adults at Wright because they talked about students in front of other people. He did say that the teachers at Hope were respectful to the students.

Having teachers who cared caused students to care more about themselves, their grades, and their futures. All of the students interviewed indicated that having teachers at Hope who cared about them had positively affected their grades.

She was only getting mad because I wasn't looking successful, you know, I wasn't being successful. I was just doing what I wanted to do instead of doing what I needed to do. She cared enough to-you know-actually make herself mad enough to-like-tell me what I need to be doing, and she actually told me, front and center. Ever since then, I had to do it. Like I was obligated to do it. It's my duty, because she cared about me. (Zach, January 4, 2011)

I build a relationship with all teachers that I've been through. I build some type of relationship with them to the point where, if I don't care about myself, they still would care about me because they still know who I am. Like actually who I am, and not just the student part of me. (Zach, January 4, 2011)

When I got As at Wright, it was-like-I'm the only one who really cares about my As. Here it's like the teachers-like-"you got an A!" And they're more happy than I am, you know. They're excited about it just as much as me. (Evan, January 18, 2011) 
They're proud of me, so by them being proud of me, I want to keep them proud of me, so I keep doing better. (Andrea, January 20, 2011)

Three of the students interviewed indicated that if they could change their home schools, they would do so by getting different teachers, preferably teachers who motivate and care about students.

Accessible. All of the students in this study emphasized the importance of being able to get help when they needed it. Students contrasted the help they had received at their home public schools and the help they received at Hope Academy; all agreed that it was easier for them to get help at Hope than it had been at their public schools. Luke identified being able to get help when he needed it as being the most important thing Hope had done to help him be successful.

[They would] help push me to succeed. Like-they would help me if I needed it. if I had problems with anything, I could get it and not wait. They help whenever I need it and they're here all the time, after school especially. Teachers at Gable, you have to make appointments before time for something like that. (Luke, January 18,2011 )

Students expressed frustration at not always being able to get help when they needed it in their public schools, and they sometimes felt that if they needed extra help, they were an inconvenience to school staff.

There-like-when I asked to get a test read to me, there it was like you were retarded, one of those weird looks, and they would send me to the office and I'd have to get the office to call someone who doesn't have a class that hour and they would go to them. It was difficult there to get some help. (Evan, November 19, 2010)

Well I'd just sit there. I'd have my hand raised and the teacher just never came to me. (Hailey, January 5, 2011)

At East, those teachers were so irritated, I don't know, they weren't irritated like they wanted to help. I don't know if it's just because the kids were bad, I don't 
know, but when I asked for help, they were like huuhhh, or they would talk all loud, or they would try to help me through it real fast so I can leave. Like-you can kinda tell when somebody, they're gonna help you, but they don't want to help you. They're just doing it because they have to. (Andrea, January 27, 2011)

In addition, several of the students remembered that they may not have asked for help in public school because they knew that they would not get it based on their past experiences; however, all participants indicated that they asked questions and for help when they needed it while attending Hope.

[Getting help] sucked at Gable. I never ever got help really when I asked for it 'cause there was so many kids in the room. They never got to me or whatever. (Hailey, January 5, 2011)

Like-at Wright, when-like-they could show that they didn't care about-like-when I raised my hand and stuff to actually like put out a question or something, no one ever called on me, you know what I'm saying? It was just-like-we'll look over here and like ignore me. I never got help when I needed it. Like-at all. I didn't-like-even when I actually wanted help to actually do something, I didn't get it, so that's why I ended up just like laying off and not even doing anything. (Evan, January 10, 2011)

I never really got help at Wright, I mean, when I did, I got looked at funny, so I didn't really ask much. And here it's-like-everybody else is asking for help, too, so I don't have to feel like I'm the only one or nothing, so I can constantly get help without feeling bad about it. (Evan, January 18, 2011)

Yeah, I would usually ask. Sometimes I wouldn't ask if I knew the teacher didn't really want to help me. (Bobby, January 25, 2011)

In later interviews, Hailey noted that she asked more questions in class at Hope because she knew that those questions would be answered and she would get the help she needed.

Students did recognize that there were some teachers in their public schools who offered help or tried to help them. Interestingly, because they were often in charge of 
discipline, a number of students mentioned their deans or assistant principals as those who provided support when the students needed it.

Mr. [school dean] told me to ask him for help if I ever needed a tutor or anything. (Isaiah, December 6, 2010)

In these interviews, students indicated that they may have been offered help, but they chose not to accept it.

Like I was telling you, they tried to offer a little help, but I didn't really-like-accept it because I wasn't trying to really-like-like-they told me I could stay after school or come in the mornings or come at lunch but I really didn't want to do any of that. (Isaiah, January 18, 2011)

East is hard to get help. Because when I wanted help, they didn't want to give me help, but then when I didn't want help, they wanted to give it to me, and they get mad if I didn't take it. It was backwards. Like-there were certain teachers that tried to help me, but I just wasn't focused, and East wasn't making me focused. (Andrea, January 27, 2011)

Students also understood the difficulty that public school teachers had with helping all of the students in their classes and made a connection between the small classes and their ability to get the help they needed.

They all tried their hardest to work around the whole student body, because there's a lot of students that go there, so I know that's hard. I don't really too much think that every teacher could get around to every student in their own personal way, like they would feel like they would want to. So as a student, you know, sometimes you got to bear out by yourself and just, like, wait for, just wait for, like, some type of assistance, because I kinda figured out that teachers can't help everybody. (Zach, December 10, 2010)

She had the motivation to help me, but she just didn't have that time, and the harping on me really-like- and she's given me so many detentions, because-like-I wouldn't come in with-like-my assignment done or completely finished, and she'd give me a detention for it. And then every time she gave me a detention, it just made me more mad at her, and more mad. (Evan, January 10, 2011) 
Evan, in particular, described an experience with a teacher whom he had at his public school. The fact that he discussed this experience on two different interview occasions let me know that it had a powerful effect on him.

One day I was struggling really hard with a test, and I asked him if I could go to another teacher to get my test read to me, and he looked at me in front of the whole class and said, "What-can you not read?" And I go, "Well, frankly, I have like a sixth-grade level, and it's kind of hard to understand this." And he said, "Why don't you just go down to one of the special ed teachers? That's where you're more fit." I was kinda embarrassed, but I kinda didn't care because it was a grown-ass man who said that who is also a teacher. (Evan, November 19, 2010)

Evan also had the unique experience of having been at Hope during middle school, transitioning back to his public high school, and returning to Hope. He saw clearly the contrast between what he had experienced at Hope, not experienced at public school, and experienced at Hope again.

It was just the academic-wise that was kind of rough on me-like-because I went from being here where everybody-like-helped me and stuff to going there to having to do absolutely everything on my own because nobody really there even wanted to like, you know, help you or anything-like-even there when I wantedlike--my tests read when I first got there and stuff, they were-like-what's your deal, you know. Just looked at me funny. So I didn't really even ask for help when I got there, I just tried pretty much doing everything on my own, seeing if I could depend on myself. That didn't really work out the best. (Evan, January 10, 2011)

Students were much more positive about their ability to get help when they needed it at Hope. They discussed their willingness to participate in class and willingness to ask questions when they did not understand.

Interest in students' lives outside of school. Students valued teachers who saw them as people with stories, not just as students. They expressed that some teachers in their public schools did not understand them or their backgrounds. However, students 
noted that staff members at Hope cared about what happened in their lives outside of school and supported them in unconventional ways. Zach identified a number of situations through which Hope staff helped him, and he named one of those as the most important thing that Hope had done for him.

Um, they've supported me through-like-what I was going through. 'Cause like the time that we just going through, when we moved into our new house, we didn't really have a house to live in at that point in time, because we had gotten evicted out of our old one. But we were staying at a hotel room for probably $2 \frac{1}{2}$, 3 months until we finally moved to our new house, and they've supported me through that because they've paid for-like-half of the room. They've paid for the room, they've bought me clothes, you know, there's a program where a teacher helped me get a job. At one point in time, they've helped me build myself to a successful level to where I'll be able to depend on myself and not others. So they got me ready for the real world, basically. (Zach, January 4, 2011)

The most important thing would be when we were going through our situation when we couldn't move and stuff like that. They kept me level-headed. It's-like-they kept me on good terms. It was-like-it's OK, we're going to help you, like that. They reassured me that there was still hope, because I was just down and out and depressed. I would always see my mother. She'd be crying because she couldn't move into her new house. It's just, we were stranded. Don't really have a lot of money to do what we want to do. They shined that light on us, letting us know, you know, we're here to help. It's OK to, you know, be in the mood that you're in, but it's also not OK to just sit there and mope around. You know, we gotta work through this together. And I feel like that was a serious enough situation to let me know that I could put all my trust and my feelings into the whole school period. That let me know right then and there that it's not just about school anymore. It's more than that, it's-like-this is a life process that I can carry with me for the rest of my life. (Zach, January 4, 2011)

Particularly for the students who were involved with either the juvenile or adult justice systems, the support of Hope staff was an important difference from the support that the students had felt from staff at public schools, which was nonexistent. Bobby appreciated the help of the Hope staff for assisting him in court and helping him with his interest in the army. 
Mr. [school dean] and Mrs. [school principal] were there every court date, supporting me. They were there every court date. Letting them know, you know, the kid has As, he doesn't get suspended, he doesn't get in trouble; he's a good, caring kid. We make sure that he's well taken care of and academic-wise, and stuff like that; he's a really good kid. They kept the judge enlightened with good things about me, and that actually helped me get out of jail. (Zach, January 4, 2011)

Mr. [school dean]-um-I'm going to court for something, for the thing for why I'm here. Mr. [school dean]'s very supportive. He's helping me stay out of trouble so I won't make the same mistakes. Helping me stay out of fights and all of that, drugs. Like he's helping me, encouraging me to do my work. He's patting me on the back; every time I see him he says stay on top of my work, all of that. He goes to my court dates. He-like-writes reports and stuff. (Isaiah, January 10, 2011)

They're-like-always, like when I was on probation, -like- Mr. [dean[, or parole really, Mr. [school dean], the principal or-like-the dean, would come to the court, would go to the court, would go to my court appearances. He would give an update of how you're doing in school and behavior wise. [They are concerned about] outside of school. Everything. (Bobby, January 15, 2011)

\section{Teacher Factors: Knowledge and Skills}

Explains academic content well. Participants identified teachers who explain things well as being a critical element contributing to their success or failure. A number of them had experienced academic frustration that led to behavioral issues at their public schools, or they did not understand the ways that teachers explained things.

People at Wright, they just give you answers pretty much. They think that once you see the answer right once, that if you see it again you can give it the right answer, and that's just not the way it works. (Evan, January 10, 2011)

Luke was able to name a teacher who had helped him because she explained things well while he attended public school.

I would understand it more because she explained it better and then the work was easier. I don't know [how]; it was just the way she explained. It was just better. (Luke, November 23, 2010) 
However, some participants indicated that their lack of understanding created a

problematic academic and behavioral cycle for them. They did not understand; they sat in class hoping they would understand and many times would not ask questions; they would not do the work because they did not understand it; they would become frustrated and not do the work; and they would get in trouble for not doing the work.

Like-at Wright it's like they, they're hoping you can read something and get it, so-like-they'll put something up on the board, like notes or something and they'll hand you a worksheet and go, "here you go." So you got to read the notes and make sure you understand the notes and then do your work. And I, when I read stuff myself, I don't really like understand it fully so I got to sit there and keep reading it and keep reading it and keep reading it and keep reading it, and finally I'll just sit there and move it around in my brain a while. And then finally I'll get it. By the time I get it, the class is already over so that's homework, and then the next class, same thing, more homework, so when I get home I'm sitting there and I'm-like-hold on now. This is, oh I don't even remember this stuff so I don't even have notes for it, and then I got to go back to class in the morning, and then get there early and try and figure it out before class starts. It was just super hard. I needed a lot more help. (Evan, January 10, 2011)

English, oh my goodness. I was so behind in that class. He wouldn't even help me. 'Cause I didn't know what he was doing. Then I was just so confused, and when I was in class, he wouldn't help me. He'd give me the work then go to the next assignment. I'd be-like-but what do, how do I do this? I don't know. (Andrea, January 27, 2011)

Students valued the fact that teachers at Hope would push them to understand the material. They stated that different teachers used different methods to help them understand. They also thought that classes were easier at Hope. When I followed up on this, students responded that the curriculum was the same. Their classes were easier because the teachers explained things better and helped the students when they needed it.

Like-if you don't, if you don't get it the first time-like-how they explain it one way, you'll ask the teacher and they'll explain it another way and if you don't get 
that then they'll explain it a different way. They'll just keep on until you get it. (Hailey, January 5, 2011)

They explain; here they explain the lesson. At Mitchell they just give you the lesson and be-like-figure it out on your own. (Bobby, January 7, 2011)

Here it's like they actually want you to learn it and put it in your head so that you can know it later on in life. And there, it's just they want you out of their hair. Here they actually-like-make you study and study and study, and-like-plant it into your brain so that you know it. It's-like-way different help. It's like they actually sit down and help you, like if your mom was helping you or something. There it's like somebody that you don't like is helping you and they just want to get it done and over with. (Evan, January 10, 2011)

Here they would explain, better explain them for me if I didn't understand. Just in a different way that I could understand. (Luke, January 4, 2011)

They're going over the assignments and-like-helping us to make sure we get it. They give examples. Lots of examples so that I can get it. (Bobby, January 25, 2011)

In addition to explaining things well, students cited the teaching of study strategies and organization skills as being important to their success. Students mentioned a number of study strategies that the teachers at Hope had taught them, including learning vocabulary, making note cards, doing examples on white boards, and picking out important ideas.

It just comes to me now. I don't know why or how. It just, she helped me-like-learn how to study, so now I don't like fail any tests or anything. She made it to where I could study for absolutely anything and help myself learn it and then, there it was just like they bribe you with candy. (Evan, January 10, 2011)

They'll like give me another way that I can find the answer or something. They'll show me where I can find it in the book-like-they won't show me the answer, but they tell me the page or something that I can find it on and stuff. (Hailey, January 20, 2011) 
Well the big one, like I keep saying, organization skills. That's actually a big one because like everything in the military's gotta be just right. Plus if I do go to college, it will help me with college. (Bobby, January 27, 2011)

Follows up. Participants expressed that they did not always understand or produce the work properly while at Hope, but their teachers always followed up to make sure that they learned skills correctly.

Like-they're helping me to remember it instead of just showing it how to do it that one time, they're-like-they make you do it and then redo it on your own to see if you got it right and then if you didn't get it right, you erase it and redo it again. Constantly do it so that you know how to do it right instead of just doing it, no one checks, and they-you just do it wrong and that's the only way that you're practicing it is the wrong way. So they make sure that you get everything right yourself the first time so that the rest of the time you're doing it, it's right. (Evan, January 18, 2011)

Students also discussed the idea that teachers at Hope did more than they needed to do for their jobs. Some characterized this as caring, but others saw it as a way that the teachers took care of all students. Hailey, Luke, and Andrea discussed that teachers helped them when it was not a requirement of the job. They clearly felt valued by the fact that teachers would take their own time to help students. Zach also stated that teachers went out of their way to help him.

That's why I say the teachers here, they go that extra mile. They actually care what happened to you instead of just, you know, doing what they have to do to get their job done and forget all about you. (Zach, January 4, 2011)

Students cited follow-up conversations and staff members checking on them as being important to their behavior change.

They help me stay on top of my grades and stuff, keep me out of trouble. Like-they check in on me throughout the day and ask me how I'm doing, how my day is going. Encourage you to do good. (Isaiah, January 18, 2011) 
While several students did describe positive teacher experiences at their public schools, the participants were unanimous in their agreement that they had been much more successful in having strong teacher relationships with teachers at Hope Academy.

\section{School Factors: Structure}

Small class size. All of the students I interviewed stated that the small class size was important to them at Hope Academy. Some students noted repeatedly that the small class size ensured that they could get more one-on-one time or help from the teacher.

There ain't as many students in class. Makes me feel like I can get more help on schoolwork. (Thomas, November 22, 2010)

[At Gable I needed] extra help-like-the teacher-like-there were too many people in one class, and I couldn't get the teacher's attention to get help... I think it's just because it doesn't have a lot of people here-like-as much as a regular school does and the classes are smaller, and I get more help than what I used to. (Hailey, November 23, 2011)

It's pretty much more teacher time [at Hope] than at Mitchell, 'cause you got like 20 some students in your class at a time. (Bobby, January 7, 2011)

I like that I got good grades now, because the teachers help me better than at like a bigger school, 'cause it's a smaller-like-environment. (Isaiah, January 10, 2011)

I like the small environment. I just-I like that they are on your case here, because if they aren't on your case, I figure I wouldn't do so well. (Andrea, January 20, 2011)

Just pretty much you get more teacher time, because you don't have the big classes. (Bobby, January 27, 2011)

Others thought that the small class size helped them stay on task and pay attention during class rather than socializing or worrying about what their peers were doing.

Like-at Wright it was more like I was just really hyper there and none of the teachers really wanted to deal with that, and here it's like when I'm hyper, the teachers calm you down in some sort of a way. They make me more calmer and 
focused in to my studies here, and-like-take the hyper and put the energy into that rather than just jumping around or acting spastic or something. Here they actually want you to take the energy and put it into this, instead of just taking that energy down to the office. (Evan, November 19, 2010) Me personally, I would have to stick with-like-the small environment, because-like-when I'm around like a whole bunch of people, I feel comfortable with and we're chilling, there's no stopping me. Once I'm going, I'm gone. I'm just kickin' it. We're having a blast until the bell rings. So I feel like this was a good decision for me because being more solitary and in a smaller environment, it kinda helped me. It kinda helped me focus more on what I need to focus on instead of lolly gagging. You know, horseplaying around. (Zach, January 4, 2011)

[Better grades] I think it's 'cause the class is smaller and I can get help faster than I used to, and I pay attention now 'cause there's barely any distractions. (Hailey, January 5, 2011)

It was loud and there was-like-a lot of people in every class so I didn't really concentrate very well 'cause I'm hyperactive. I got ADHD and stuff.

So-like-someone would talk to me, so I'd start talking to them and then it would be like a big conversation with everybody, so-like-we couldn't get no work done anyways, and then when we did get the work it was last second. Like-here the classes are so small and stuff, they don't ever get out of control or nothing. (Evan, January 10, 2011)

School size was also important to students as they talked about the building as a whole in addition to individual classrooms.

It's a smaller setting. It's less stuff to get into. You can't leave off the floor. You can't go ditching and stuff like that. (Isaiah, December 6, 2011) Uh, it's a smaller place, so, you know, the classrooms are reduced, the hallways are smaller, so I can really only have one choice - but to pay attention to the work. (Zach, December 10, 2010)

I mean that way it's not-like-out of control, 'cause like when it's-like-when you're in a big hallway and stuff-like-people are pushing and kicking and tripping and slapping books out of hands and stuff. Here-like-if you slap someone's books out of their hands in the hallway, you're getting caught. You're gonna get in trouble for it. It's-like-if you trip somebody out there, you're getting caught, you're getting in trouble for it. If you try and fight out there, you're gonna get caught within-like- 3 seconds. There's nothing you can really do but go to class. (Evan, January 18, 2011) 
Cause you ain't got a lot of stuff, like, you can't go out to lunch and then be-likeno I don't feel like going back, cause you don't really have a lot of freedom and stuff. Then at passing periods too, it's good that they don't have passing periods here 'cause I used to be late a lot, and sometimes-like-during passing periods I'd go with my girlfriend or something and be-like-I ain't coming back. (Isaiah, January 18,2011 )

A bigger setting will make me want to ... peer pressure is hard, so it'll make me want to go, oh, I can just go over here and not get caught. But then I constantly do it, and I get too behind. In this setting you can't do it. And I like a smaller environment so I can do more, I can do what I got to do and then leave. (Andrea, January 27, 2011)

While all students recognized that small class size was a good fit for them and they were more successful at Hope, some did miss the class size and extracurricular offerings of their public schools. Evan enjoyed the metals shop course that he had taken at his public school and wished that he could take more industrial arts courses. Andrea and Thomas wanted a school with sports. Zach called his public school experience exciting and noted that his public school was a good fit for a lot of students.

My favorite part of school there was the size of it. I think that's what the best part was. Seeing so much stuff in there. Just-like-all the side academics and afterschool programs. Just a lot of things to keep a child's interest, you know, keep them wanting something. Everything that you could think of they had. (Zach, December 10, 2010)

They're good at providing places where you can work at. They're good at providing tutors. They're good at helping you, getting ready for college. They have so many side things that you can go through in order to succeed. I feel-like- if they keep doing what they are doing, a lot of kids are going to make it. (Zach, January 4, 2011)

Interestingly, Zach and Andrea said that if they could change Hope, they would make it bigger; however, when I pressed them on whether or not that would be good for them, they agreed that it would not. Although students recognized that the small environment 
was important to their success, they said they would still like to have their school be more like a typical high school.

Clear student limitations. Several of the students I interviewed were truant when they attended public school. They may have skipped selected classes or full days, but they were all certain that they could continue skipping without consequence at public school. Hailey and Andrea stated that they needed someone who knew and cared about them to tell them to get back to class. Students contrasted their experiences relative to attendance at Hope Academy and public schools.

I think they should have been, really been on the students more (at East High School). They really wasn't on us, we could skip and we wouldn't get in trouble for the skipping. (Andrea, November 22, 2010)

Oh yeah, you can't skip class here. Where you going to go? (Hailey, November $23,2010)$

Because if you skip or anything, you can't come back until your parents come and talk to them, if you skip [at Hope]. [At Gable High School] I would come to school, say I would go to first hour, miss my second hour, come back to school go to third, miss fourth hour, then go to lunch, then go to sixth hour, miss my seventh hour, like that. (Luke, November 23, 2010)

[At] Gable, the hall monitors and stuff, they suck. They let you skip and do whatever. And here you can't skip or nothing, 'cause there's no place to go. And there's teachers walking around everywhere and stuff to tell you to get to class. (Hailey, January 5, 2011)

[At Hope] if I skip, my parents would automatically be notified, and if I skip a lot, I'd be in trouble with the police. [At Gable] it was like a phone call in the middle of the day, which my dad would be asleep because he works nights, and my mom's not at home because she's working days. And nobody would know. So I kindof got that into my head that I could get away with it. (Luke, January 18, 2011)

You can't skip here. You could skip there. That was a big problem for me. And I used to, as much as they tried to make it that you can't leave at lunch, we all would leave. And if you got caught you would get in trouble so many times. You 
can't leave here. Can't go nowhere. Where you going to go? It's just, you could do too much there. (Andrea, January 20, 2011)

Students discussed the structure of Hope related to other issues as well. Zach raised the issue of fighting and the fact that it is not tolerated at Hope.

They don't support violence, I know that for sure. Like-if there was a fight going on, instantly, break up, restraint maybe. You guys can't, you know, you can't be fighting. That is not something that they really approve of; they don't approve of it at all. They don't approve of it at all, you know. It's-like-they're on it. That's why they're kindof more strict, because it's-like-nobody wants to sit up here and be watching kids fight all day. Nobody, kids or teachers. (Zach, January 4, 2011)

They got low tolerance here. It's a good thing with the fighting that they got low tolerance. (Andrea, January 20, 2011)

Other students discussed the expectations in general and thought that the expectations were fair if sometimes strict.

Yeah, those are-I mean-I-already, expectations are already there. I mean, you don't fight, you don't cuss, I mean, it's all common sense stuff. It's not like they're asking you to-like-hold your foot and hop down the hall or anything. (Zach, January 4, 2011)

\section{School Factors: Culture}

Family environment. Several students talked about Hope as a family environ-

ment. Evan used the word family three times during his first interview to describe the atmosphere at Hope, and other students chose the word as a descriptor as well.

It's not like a regular school it's more of-like-one big kinda family... It's like this is so small it's like a big huge family here. Everybody gets along with everybody, the teachers work together. At Wright they are their separate selves; they all do their own thing. (Evan, November 19, 2010)

I see something different in Hope. I don't see just a bad school, I see a family, a family of staff that actually care about you. The relationship here, it goes, it breaks the bonds of student and teacher. It brings y'all together as a team, and as a team, you know, there's too much nothing you can't do when you have a strong 
enough team. That's why I feel like my team here, we're undefeatable. (Zach, January 4, 2011)

There's a teacher here that, she's one of those teachers where she's not you're your teacher, but she's like your mother. (Bobby, January 7, 2011)

Mr. [teacher], the art teacher. He's just funny and big. He's like a big brother. (Bobby, January 7, 2011)

My observation of breakfast and lunch times reinforced the idea that students and staff interacted in a familial style and were part of the same team.

Student accountability. Students were accountable for their own behavior at

Hope Academy. They took responsibility for their actions and felt that they were treated fairly.

It's-like-they give you a chance to explain your side and then they give the other person a chance to explain their side. That's only fair, you know, it's a fair action. Instead of just-like- OK, well, he's suspended, she's expelled, instead of just cancelling out students, you know, they actually sit down and take the time to actually investigate what happened if there's any type of conflict or, you know, altercation that happened. They always look at both sides and not just the one side and they go based off the whole story, period. Therefore, I think they're pretty fair to me, because every time I've got in trouble, they gave me a fair trial. I was always, I had my defense; they had their defense. And then it came to a verdict. You know, I can only respect, and you know, follow what their consequences are, because the simple fact is it's my actions and I did it. (Zach, January 4, 2011)

If you skip, you won't go to class, then you won't learn anything. (Hailey, January 5, 2011)

[Interviewer: "So if you're in the hallway here and one of your teachers says, 'Hailey, get to class,' is that something that bothers you or you don't mind that they're holding you accountable to that?'] No, because that's the rule. But they do it in a nice way. I know they want me to do better. (Hailey, January 20, 2011) [Interviewer: "How could you have done better at Hope?"] Not made the threat that got me a felony (Referencing the incident after which he was arrested at Hope). (Bobby, January 25, 2011) 
Students knew that at Hope they would be judged by their own actions rather than by other factors and would be held accountable for meeting the school's expectations.

Yeah, it's just all counted on your behavior here. They just want everybody to be like, behaved, and come to school. Yeah, as long as they're like here every day and they show up, the more they show up the more they get liked, and then the better their behavior, the more they're liked. It's just the better they're doing in their classes the more they're liked instead of like, he's a starter in football, so he automatically gets an A and we like him. (Evan, January 10, 2011)

They call home every day if you are late. They'll send you right home if you are late, and then they call home on your grades, if they're good or not. They do a lot of stuff. They make you get to class on time. Stay focused. (Andrea, January 27, 2011)

Like-my behavior and my future-like-my behavior can stop me from doing the things I want so I need to change it sometimes. (Bobby, January 25, 2011)

Evan and Isaiah likened school at Hope to a job. They noted that teachers were always on students to do what they needed to do.

Here it's-like-you're taking care of a kid or something. Like-did you just feed the baby? No, I didn't. Well you need to go do that. [At Wright] I could just leave the baby with a full diaper and crying. They're-like-your kid's over there crying, well that's your job. (Evan January 10, 2011)

Like-being consistent-like-coming to school - it's like a job. Like-they prepare you for-like- they told me like school is a job. If you want to look at it that way. Like-if you're getting As, you're getting paid good. If you do good in school you'll do good on your job, I guess.

Motivation systems. Students discussed the accountability systems that were in place at their public schools, particularly those related to attendance. Students reported no positive motivations systems, relating only consequences that they had received for behavior.

Because there [at Gable], they don't really make you do anything. It doesn't matter whether you're skipping or not. I mean, they'll give you [detention] 
minutes, but it doesn't really stop you from doing what you're doing. Which is what I thought, so I just kept on skipping. (Luke, January 4, 2011)

They had a checkmark system. If you didn't bring in your homework the first day, you didn't get a checkmark, but if you didn't bring it the second day, then you did get a checkmark. And if you had to go to the bathroom in the middle of class, then you got a checkmark. And it was-like-11 checkmarks and get a detention, and I got one-like-every day. (Bobby, January 7, 2011)

If you didn't get caught, oh well. It's like they didn't care, and then, sometimes, it's like they knew you would skip, and they wouldn't call you in, they would just put [detention] minutes on you and you got to serve it. Sometimes, like at the end, before I got expelled, that's when they tried to act concerned, before I got expelled. I was expelled then, that wasn't going to do too much for me. (Andrea, January 20, 2011)

As I also noted in my report of the findings on teacher factors, many students were motivated to be successful by the relationships they had built with staff members at Hope and by the expectations that those staff members had of the students. Bobby, Isaiah, and Andrea talked about teachers' ongoing verbal reinforcement and praise that motivated them to do better.

I like Hope. It keeps me on track, just to go to class, it keeps me motivated. (Hailey, November 23, 2010)

Basically it's the teachers-like-they help-like-they help you stay on top of your work. Tell you what you need. Like-if you need to improve in something, they'll tell you. Pat you on the back if you're doing a good job. Yeah, 'cause it's like motivation. And you need motivation. (Isaiah, January 18, 2011)

Because it's-like-here you can't do everything you could do at a regular school. It's-like-they motivate you. They say, "Get to class, you're going to get an OR [office referral]." There's only so many ORs you can get. Then if you're late to school, they'll send you home, so you gotta make it to school on time so you won't get sent home. Then they got honor roll, and they help you, when you make honor roll, you got a little dinner. They got different activities where you want to get good grades and stay maintained. (Andrea, January 20, 2011) 
Aside from personal relationship motivators, Hope has a level system in place that will help motivate students to have appropriate behavior. Students discussed this level system, and the point sheets that I saw during observations were the data collection method used to determine whether or not students had good days.

Or-like-here they have-like-the professional and apprentice. It's-like-if you're good for 30 days or 25 days or something, you can be an apprentice. You can go downstairs, smoke a cigarette or something once a week during lunch. Or-like-go downstairs and get a Subway sandwich or something once a week. And then if you're professional, which is like good for 50 days or something, you can go downstairs everyday for lunch and stuff, and-like-that helps out people here and stuff. (Evan, January 10, 2011)

Behavior incentives. Like-if you're good for 50 days, you can become an apprentice. No, I'm sorry it's 25 . You get to go down every Friday for lunch at Subway, or whatever you want to do. Sometimes they do other activities like field trips or movies, too. (Bobby, January 25, 2011)

\section{Changes in Students}

Motivation. All students reported that they were motivated to succeed; they equated success with earning credits and graduating.

At Wright, my whole freshman year, I didn't pass but one or two classes. The second I came here I maintained all As my whole sophomore year, and I think right now, I do not have a $\mathrm{C}$ right now in any of my classes. (Evan, November 19, 2010)

I come to school, I look forward to coming here, though...because I know that I'm gonna graduate, if I go back to East I don't think I'm gonna graduate.

(Andrea, November 22, 2010)

Just getting all my credits back, because the way I was going, I wasn't going to be a senior. I was going to be a super-senior or something. A super-super-senior. [At Gable it would have taken] a while. Honestly, probably another 2 years. So, a total of 6 ...I work harder because I know that I need to graduate. (Luke, January 4, 2011) 
Passing English, 'cause that was my hardest subject in the world at Wright, and stuff, and I thought I would never graduate on time because I wouldn't pass English class. And I passed my English class last year with an A, and I passed it this year first semester with an A, and I'm going to pass it this semester with an A. So I feel I've accomplished that. All my As - I love As now and I never used to care about that. I used to get all Fs, and now I get all As, pretty much. So I feel when I accomplish an A, that's very good. I probably wouldn't get As. My goal would be Ds. At least D means diploma. (Evan, January 10, 2011)

Yeah, 'cause-like-I care about grades now. It's just a change, because back then I just didn't care. I didn't care. I don't know why I didn't care-I was-I just liked to have fun. Like the only period I looked forward to was lunch and PE. But now I look forward to going to class. (Isaiah, January 10, 2011)

[Interviewer: "Why do you care more about grades now?"] Because it's like they opened my eyes to make me want a better future than what I did before. (Hailey, January 20, 2011)

I know I'm on the right track to graduate, and I'm doing what I got to do. (Andrea, January 27, 2011)

I've matured a lot. I was getting all Fs, all straight Fs on my report card, now I'm down to one F. Plus, I'm figuring out what I want to do with my life. (Bobby, January 27, 2011)

Students reported that they were not motivated at their public schools and that they did not put effort into their school work. The fact that several students acknowledged their lack of effort indicates their levels of self-awareness. I will discuss this further in a later section.

I probably would have dropped out. After getting Fs for so long I probably just would've dropped out. (Thomas, November 22, 2010)

I never was trying hard at Gable. (Isaiah, December 6, 2010) It's like I try hard now. It's like I changed, I guess. (Isaiah, January 10, 2011)

I just wouldn't do my work, which would drastically affect my grades. So I would get bad grades...Not doing my work, homework, skipping class. That took out of my participation grade. (Luke, January 4, 2011) 
I didn't really study at all at Wright. (Evan, January 10, 2011)

I would have never done that at Wright. I would have just failed and then been a super-senior and then another super-senior, and then probably just got kicked out. (Evan, January 10, 2011)

If I knew what I knew now back then, things would go a whole lot differently. (Zack, January 10, 2011)

Bad. I know it was bad. I messed up on my freshman year, so that kinda set me back. Well, it didn't set me back; I just have to work harder because I was skipping, I never went to class, I never really did homework, sometimes, yeah I wasn't doing it a lot. (Andrea, January 20, 2011)

Determination to succeed. Students were determined to succeed in school and

life, and they knew that staff members at Hope Academy would help them succeed.

[This is the last stop] before-like-not being able to go to school. And I want to get an education. (Isaiah, January 10, 2011)

I can say that they helped me graduate, from Day 1. It's-like-because when I was a freshman, I never used to think, you know, I never used to think about graduating and stuff like that. I always used to, you know, think about something different. I feel like when I was a freshman, I never would be able to-like-I could never see myself walking the stage. It was always just like a blurred vision to me; it was like I couldn't see it. They actually provided the glasses so I could be able to actually be able to see that. It's-like-it's there. All I got to do is work for it. They put it in front of me. All I have to do is go get it. (Zack, January 4, 2011)

[I'm proud of] probably getting, probably getting my felony dropped down to a misdemeanor. I worked and worked until I saved up enough money to get the papers, then I filled them out and went to court. (Bobby, January 25, 2011)

They've helped me realize that if you really want to make it you can, and we're here to back you up. (Zack, January 25, 2011)

I'm trying to get out of school, I want to go to college. I would be in high school forever if my grades aren't good. I need to get my credits. (Andrea, January 27, 2011) 
I asked students if there was anything that Hope did not do that they needed to be successful. Bobby named sports as the only thing he needed that Hope did not provide. Andrea, Evan, Isaiah, Thomas, Zack, and Hailey acknowledged that there was nothing they needed that Hope didn't provide and that Hope provided everything they needed.

I don't think there is anything here that they could do more to help. (Evan, November 19, 2010)

I think everything that they have supported me with or gave me, I have used to my advantage. There's pretty much nothing that they don't give me. (Zack, December 10, 2010)

Students agreed that they had not been successful in their public high schools.

They cited grades, behavior, lack of interest, and the fact that they had to come to Hope as evidence of their lack of success.

Nah, I don't think I was, because I had to come here. (Luke, November 23, 2010) I just didn't pay attention. Umm, my smart mouth with teachers. And then, um, sometimes I would fight. (Hailey, January 5, 2011)

I just wouldn't really have got stuff done and I'd end up really far behind. I'd end up being a super-senior there, have to take an extra year of school just to catch up on credits. (Evan, January 10, 2011)

I don't want to go back, because I'm doing real good here. I've been on the honor roll ever since I've been here, and I know if I go back there, I don't think I could do...well, I can, but it's-like-there's going to be so many distractions. (Andrea, January 20, 2011)

Self-awareness. Several students took responsibility for their lack of success at public school, citing specific behaviors that caused their failure.

I pretty much think they gave me everything I needed. It was just up to me whether I was going to use it or not. Closed mouths don't get fed. You know, when I wasn't ready to learn, I didn't learn. Now I am and I feel like I can learn more. (Zach, December 10,2010) 
[Interviewer: "Could you have been successful at Gable?"] Maybe, if I would have put forth my effort and not just give up on everything... I mean I could, but it's just the fact that I didn't want to. So it was my choice, and I kindof gave up. (Luke, January 4, 2011)

I was too busy trying to have fun and I wasn't doing what I was supposed to do in the classroom. I don't want to get in their mess. Like-I just want to come here and do what I got to do so I can go back to Gable...the help that they offered, I didn't really want to take it-like-I was-like-stubborn if you want to put it like that. Like-selfish or something like that. I was just not willing to learn. I didn't really care, I was just caught in the life of having fun. (Isaiah, January 10, 2011)

[Not getting help] Right, that was-like-some of it, but I couldn't blame it all on that, though, because I did just goof around a little bit, too. (Evan, January 18, 2011)

Hailey acknowledged her past behavior, but was also worried about how it would affect her in the future.

I don't know, I just think like I'm going to mess up sooner or later. I don't know, because I just got a little feeling like I'm going to skip one day and never want to go back to chemistry or whatever. (Hailey, November 23, 2010)

My interviewees also owned their more positive behavior that they were exhibiting at Hope Academy. The students exuded motivation and determination to succeed, and they recognized those feelings as being specifically different and changed from what they experienced at public school.

I like Hope. It keeps me on track; just to go to class; it keeps me motivated. Instead of skipping and stuff. (Hailey, November 23, 2010)

I made the progress because of the simple fact that it was either now or never. It was-like-if I don't do this now, I'm going to end up, you know-like, like-a good example of who I'm not trying to end up like is my brother, my older brother. Quit school, you know, start smoking weed, whatever like that. Just gave up. He just stopped. I always looked at that, you know, I used that as a stepping stone for me. I know I can be better than that. I choose to be better than that, so, therefore, I work harder, and, therefore, I will achieve if I do work harder, so I put my mind 
to it. When I put my mind to it, anything's possible, and everything has been possible. Because I've made the change for myself because I don't want to be like everybody else, you know, I want to be something different. I want to be able to say I made it. (Zack, January 4, 2011)

Talking to me changed me. It meant telling me what's right and wrong sometimes and making me think about what I'm doing and stuff. (Hailey, January 5, 2011)

I stopped skipping classes a lot. Stopped coming late. Started going to school more. Stuff like that...it was just time to make a change, 'cause I'm going through all this court stuff, and I'm trying to do good in school... There's morelike-there was help at Gable, but I'm accepting the help here, and it was-like- all this time it was a personal choice that I just had to do the work and accept, accept the help. (Isaiah, January 18, 2011) They did a good job. They changed me. From the beginning, I changed. I don't skip no more. I don't think about skipping. And I come to school. I behave. I got a smile on my face. (Andrea, January 20, 2011)

[At Hope] I want to be there. I didn't want to be there at Gable. I like class now. (Hailey, January 20, 2011)

[At Hope, we talk about] my behavior and my future, like my behavior can stop me from doing the things I want so I need to change it sometimes...most of it came to me on my own. Some of the talking with people helped, too. (Bobby, January 25, 2011)

I figure as the time progressed and I got older, I started learning more life lessons as far as-like-you make the grade; you make your own appearance; you make how people are going to reflect on you in the future or in the past or in the present. (Zack, January 25, 2011)

\section{Findings Related to Research Question One}

What are the perspectives of students enrolled in a regional safe school regarding their experiences and the effectiveness of the schooling in their home schools and regional safe school?

Students discussed their overall experiences and levels of success relative to Hope Academy and their home schools. Students equated success with grades and progress 
toward graduation and postschool outcomes. If they did not achieve or work toward success, students did not see their schooling as having been effective; therefore, whether or not students judged schools as effective was contingent on their individual performance there.

Andrea described her experience at East overall as "Bad. I know it was bad" (Andrea, January 20, 2011). She had ongoing peer conflicts and skipped classes regularly. Andrea was pleased overall with her success at Hope. She was proud of her academic progress, the fact that she would graduate on time, and the drastic improvement of her grades.

I got a smile on my face. I got a-well I had a smile on my face at East, but it's-like-I was, I had a smile on my face but it was a fake smile. My frown, if I didn't fake smile you would see my frown. I'm happy here and I do way better. (Andrea, January 20, 2011)

Bobby thought that his public school experience did not go well overall. He had some trouble with peers and received a number of detentions for his behavior. He said that his experience at Hope had been better. He made this judgment based on the number of suspensions that he had earned at both schools and said that the number was significantly lower at Hope. Bobby reported that when he first came to Hope, his behavior was still inappropriate and disrespectful, but he had improved it over time.

Evan identified his home school experience as fun because of sports, but aside from sports, "kinda horrible" (Evan, January 10, 2011). He identified trouble with peers, teachers, grades, and behavior. In contrast, Evan identified no peer trouble at Hope, since he felt as though he had an equal peer group there. In addition, he thought that peers at Hope were more likely to be at school for an educational rather than a social purpose. Evan was proud to name his grades at Hope as they were much improved over those he 
had earned at Wright. His teacher relationships, discussed in greater depth in a subsequent section of this manuscript, had improved. Evan had earned no suspensions while at Hope, but had been suspended multiple times while at his home school. Overall, Evan identified his school experience as being more positive and effective at Hope than at Wright.

When I asked Hailey about her experience at Gable overall, she responded, "I think it went horrible" (Hailey, January 5, 2011). She reported that she had trouble with being disrespectful to staff members, skipping class, not doing homework, and earning bad grades. At Hope, Hailey thinks that things are good overall. She attends school, she has better relationships with teachers, and her grades are much improved. She anticipates that she will graduate on time and does not think that would have happened if she had stayed at Gable.

Isaiah described his overall experience at Gable as fun. He had been popular but had not taken his education seriously. At Hope, he looked forward to going to class and had found a balance between education and social interactions. He identified that he had needed Hope to "get back on track" (Isaiah, January 10, 2011). His grades and attendance had improved at Hope, and he hoped to take that success with him when he returned to Gable.

Luke described his overall experience at Gable by stating, "It wasn’t good" (Luke, January 4, 2011). He did not have trouble with peers or teachers at Gable; his primary issue was with skipping classes and the resultant grades he earned. Conversely, Luke described his experience at Hope Academy as good. He said that his attendance and grades were much improved over those he had earned at Gable. 
Thomas described himself as more successful at Hope Academy than he had been at Wright. He said that his grades, behavior, and teacher relationships were much better. Thomas could identify nothing that he liked about attending public school, and he seemed to have particularly toxic relationships with teachers.

Zack used the word exciting to describe his overall experience at Adams. He said that the school gave him a rich feeling and that people there expected great things of students. When asked to describe Hope overall, he said "Hope, I would say...it's my home" (Zach, January 4, 2011). Zack consistently expressed positive feelings about Adams School; however, the positivity was directed toward the wonderful things that the school offered and expected in general, not what it offered and expected of him. He stated that he was sure that Adams did much good for many kids, but he asserted that Hope had been the necessary choice for him to be successful. He credited Adams, expressing thanks a number of times during our interviews, for recognizing that he needed more and for sending him to Hope.

All students acknowledged that they had not been especially successful or they would not have come to Hope at all. In addition, all recognized that they were more successful in the areas of grades, teacher relationships, and behavior at Hope than they had been at their home schools. Evan, Andrea, Luke, Thomas, and Zack did not want to return to their home schools.

\section{Findings Related to Research Question Two}

What are the perspectives of students enrolled in a regional safe school regarding strengths and weaknesses of the services and programming received at their home schools and regional safe school? 
Academically, students were generally pleased with the services and programming offered by Hope and by their home schools. They did not identify one curriculum as being more difficult but did say that the curriculum at Hope seemed easier because they were always able to get help with it when they needed.

No students identified special education programming as being particularly important to them at public school. Evan and Thomas did say that they liked their sixth grade resource teachers, and Hailey said that she had a resource class but generally skipped it. Evan also mentioned a special education teacher and aide who were particularly helpful at Gable. He specifically noted that he had a class that had two teachers, but that one did not really know what was going on in the class, so she was not helpful. In addition, he had a great deal of trouble getting the accommodations that he needed without embarrassment while at Wright. Bobby cited his football friends as his primary source of help, but he did talk about his football coach, who would also be his case manager. Bobby did not mention how his coach would help him academically. A number of students said that they saw a social worker occasionally, but only Andrea mentioned that it was a regular appointment or particularly helpful.

Special education services at Hope were regarded more highly by students. They consistently identified their resource teacher as a person who would help them with accommodations, test-taking and study skills, and explaining information. Some students (i.e., Andrea, Bobby, Evan, Hailey, Isaiah, and Zack) said that they could not clarify how she did it, but that the special education teacher could keep explaining things in different ways until they understood the material. Andrea, Evan, and Thomas said that they saw a social worker regularly and that the social worker had helped them talk through difficult 
situations. Bobby used to see the social worker regularly but at the time of his interview sought the social worker out only when he needed help.

Hope Academy did provide students some programming opportunities to which they had not had access while attending public school. Luke and Andrea had enrolled in a self-paced, computer-based credit recovery program. They indicated that they had not been able to do that while attending Gable or East High Schools. Andrea and Hailey had participated in the Workforce Investment Act (WIA) program. It was a program that emphasized vocational skills, job placement, and community service.

There were some courses offered by their home schools to which students did not have access at Hope. Andrea missed taking her cooking class. Evan talked of a metals course that he had taken at Wright and wished that he could have taken a woodshop class as well; however, Hope did not offer industrial arts classes. Zack thought that there were things he may have missed by not attending Adams, but he was not sure what those things were.

A number of students identified opportunities they thought they might have missed by attending Hope rather than their home schools. Andrea, Bobby, and Evan named sports as something that was missing from Hope. Andrea wanted to be a cheerleader. Evan also wished for an improvement in the lunches served at Hope. Isaiah thought that he might miss some of the social things that were going on at Gable. Andrea, Isaiah, and Zack said they sometimes thought that Hope should be bigger, but they worried that it might not be as well structured if it expanded. Hailey, Thomas, and Luke did not think that they had missed any opportunities by attending Hope. 


\section{Findings Related to Research Question Three}

What do students identify as the key elements to their success in school, and what are their comparative perspectives on how their home school and regional safe school address those elements?

As presented through the concept map and student quotes from interviews, there were several teacher and school factors that students identified as being key elements to their success. The teacher factors identified by students were teachers who care and teachers who are willing to help students when they need it. The school factors identified specifically by students were fair treatment and structure.

Teachers who care. Andrea reported that having teachers who care was important to her success. She named several teachers at Hope Academy with whom she had built strong relationships. These teachers helped her by talking through life issues as well as academic problems. Andrea also named a teacher at East who had talked with her during times of peer crisis.

Bobby reported that having teachers who care was important to him and named teachers at both Hope and Mitchell who cared about him. For both of the teachers, Bobby cited their concern about his life outside of school as proof that they cared. Also, he stated that one of them had told him directly that she cared about him.

Evan identified teachers who care as being essential to his success. He said that generally he did not have teachers who cared about him at Wright and could only identify one sixth grade teacher with whom he had a good relationship. He felt ignored and invisible at Wright, since he was not an athlete. This differential treatment of athletes was echoed by Thomas. Conversely, Evan described the staff at Hope as "family" (Evan, November 19, 2010). 
Hailey identified having teachers who care as being important to her. She thought that teachers at Hope took more time to know students, and, she thought, then they were able to relate to and deal with them better. At Gable, Hailey did not feel like teachers got to know students, so the teachers just reacted to students by sending them out of their classrooms instead of asking them what was going on. To her, this meant that the teachers at Hope cared more about their students than did the teachers at Gable.

Isaiah said that having teachers who care was important to his success. He thought that teachers at Gable may have cared about him but that he did not accept their caring, so they stopped showing that they cared. He also had teachers who cared about him at Hope, and he accepted their caring, help, and attempts to interact with him.

Luke said that having teachers who care was not important to his success; however, in the next breath he contrasted his teachers at Hope as being those who cared more than the ones that he had at Gable. Luke was able to identify one teacher at Gable with whom he had a good relationship. He liked her class because the work was easy, and he thought she explained it better. Luke indicated that he knew the teachers at Hope cared about him because they pushed him to do his work and made sure he got it done. His teachers did not do that at Gable.

Zack thought that teachers who care were essential to his success because of the relationship-based person he was. He identified teachers who cared about him at both Adams and Hope. Zack placed a great deal of importance on these relationships, and he stated multiple times that he knew he would value the relationships he had formed with teachers throughout his life. 
Teachers who are willing to help when needed. Like some of the other students in this study, Andrea regarded having teachers who care and those who are willing to help students as the same. Andrea named specific teachers who helped her at Hope but was unable to name teachers who helped her at East. Although Andrea did name one teacher with whom she had a good relationship, Andrea did not say that the teacher helped her with her academic work.

Bobby thought that having teachers who would help him when he needed it was very important. He reported that he always got help when he needed it at Hope and that teachers would respond to student questions or ask who needed help. Bobby said that he did not get much help from his teachers at Mitchell, but he wondered if he might get more help now that he was in high school.

Evan asserted that he never got help when he needed it at Wright, which caused him to stop asking for help. Instead, he sat in class and did nothing. At Hope, Evan stated that teachers were always willing to help him, and that, sometimes, he did not even have to ask.

Hailey identified having teachers who would help her when she needed it as important. As with other students, Hailey related this to whether the teachers cared about her. She was very happy with the level of teacher support that she received at Hope. Hailey stated that there was always someone there to answer her questions and that her teachers took their own time to do something that would be helpful to her. When I asked Hailey how Gable did with providing teachers who help, she replied, "Gable, I think they sucked with it" (Hailey, 1/5/2011). At Gable, she could not identify times when teachers 
had helped her, but she did remember the occasions on which she sat, hand raised, and received no response from her teacher.

As he had with having teachers who care, Isaiah believed that having teachers who would help him was important to his success. For Isaiah, the two concepts were actually interchangeable: If a teacher cared about him, she would help him; if she did not care, she would not help him. As stated in the previous section, Isaiah believed that teachers at Gable cared about and would have helped him if he had accepted their help. At Hope, he did accept the help teachers offered.

Luke also identified being able to get help when he needed it as being an essential element to his success, because sometimes he needed help on things that he didn't understand. He felt that he had received a little more help at Hope than at Gable. He also talked about the accessibility of the teachers at the two schools. At Hope, he could ask a teacher to stay after school and help him; at Gable, he was expected to make an appointment if he needed help after school.

As with teachers who care, Zack thought that he had opportunities to get help from teachers at Hope and Adams. He thought that both schools did a good job of making sure that students were supported academically and cited teachers, tutoring programs, and after-school help as methods that both schools used to help students academically.

Fair treatment. Andrea thought that fair treatment was important to her success. She thought that the treatment of students at Hope was equal, which she thought was fair. At East, Andrea thought that teachers showed favoritism to certain students, not disciplining them for violating rules when other students were disciplined. 
Bobby also thought that fair treatment was important. He thought that he was treated fairly at Hope and referred to the fact that everybody gets the same number of chances. At Mitchell, Bobby was unable to give an example of when he was treated fairly, but he thought he was probably treated fairly sometimes. He stated that it was too long ago for him to remember.

Evan did not identify fairness as an essential element, as long as teachers being unfair did not mean that he did not receive the help he needed. He thought that students were treated fairly at Hope; however, he did recognize the favoritism shown to athletes at Wright.

Isaiah thought that fair treatment was important to his success, and again equated fair treatment with getting the help that he needed. He mentioned one teacher at Hope who was very fair in making sure that she helped all of the students in the class. He was unsure of whether treatment had been fair or not at Gable in either classroom or discipline situations. Luke said that fair treatment was "sort of" (Luke, January 4, 2011) important to his success. He did not see a difference in fair treatment between Gable and Hope, and he felt that he had been treated fairly in both schools.

Hailey agreed that fair treatment was important to her success in school. She thought that Hope and Gable were generally fair, but that she had been in trouble for arguing with teachers in situations that she thought were unfair while attending Gable. She thought that students might become frustrated when they thought that teachers were unfair and that this could cause them to get in trouble.

Zack said that fair treatment was important to him and that he had always felt as though he was treated fairly at Hope. He related this primarily to situations in which he 
had been in trouble and Hope staff had listened to his perspective. Zack noted that when this happened, he accepted the consequence of his actions, because he knew that it was decided fairly. He said that at Adams, it may have been that teachers gave more weight to a certain side.

Structure. Andrea said that structure was very important to her. As one of the students who had attendance concerns prior to attending Hope, Andrea recognized that the closed campus of Hope was essential to ensuring that she attended school all day every day. She also liked the small environment of Hope because it meant that someone would be following up with her and making sure that she was doing what she needed to do. Andrea reported that at East, she could skip class and not get caught. She believed this because school personnel seldom addressed the issue with her. She equated this lack of structure with a lack of caring on the part of the staff at East.

Bobby said that the small classes part of the structure at Hope were very important to his success. He said that the most important thing about small classes was that the teacher would have more time to work with and answer the questions of individual students. Bobby did not identify any elements of structure that helped him at Mitchell but said that he had "just learned to deal with it" (Bobby, January 25, 2011).

Evan identified structure as being an essential element to his success, and he equated structure with teachers holding him responsible for his work and actions. He stated that the structure was not in place at Wright, because staff members did not care whether students failed or not; however, at Hope, teachers were constantly following up on whether or not students had taken care of their responsibilities. 
Structure was important to Hailey's success. Like Bobby, Hailey agreed that the small classes were an important part of the structure at Hope. She equated this with more attention from her teachers. Hailey also agreed with Andrea, since both had attendance problems at their home schools, that the structure in place that prevented students from skipping their classes was essential. She directly tied the decreased skipping and the small class sizes to her achievement. Also helping her attendance were the teachers in the hallway who directed her back to class if she roamed. At Gable, Hailey noted that they had hall monitors, but that those monitors let students skip and never redirected the students back to class.

Isaiah agreed that structure was an essential element of his success. He associated structure in the environment to discipline and stated that "you need discipline so you could learn from your own mistakes" (Isaiah, January 10, 2011). Isaiah thought that Hope was stricter than Gable with consequences and making sure that students did not skip classes.

When asked about structure, Luke indicated that it was not essential to his success; however, he agreed that without the structure of the environment at Hope Academy, he would have continued skipping classes as he had at Gable. He did identify a lack of structure as a weakness of Gable, because he consistently felt as though he could skip and not get caught.

Zack associated structure with kids' ability to fight and get away with other inappropriate behavior. He said that structure was very important to his success because fighting has no place in school. He thought the structure at Hope was very good and called their way of dealing with violence "superb" (Zack, January 4, 2011). Conversely, 
he thought that there were fights all the time at Adams because of the size of the building and the teachers' inability to respond quickly to situations. He thought that it was easier for students to take advantage of the situation and plan around where staff members would be. Zack also thought that the ability to be flexible within structure was important at Hope. He said that there had been times when he needed to leave class and talk to someone or clear a block of time to work on a project, and Hope had been able to do that. He did not think that Adams had the ability to be flexible to meet students' needs in that manner because of scheduling.

\section{Chapter Summary}

Chapter IV included a summary of the findings of this study. I described findings that emerged from my document review, observations, and interviews. My review of documents indicated that Hope Academy was an appropriate site from which to recruit participants for this study. My observations provided a picture of the day-to-day operations of Hope, and supplied me with a knowledge base from which to conduct interviews. I identified the themes of clear expectations, a student-centered environment, and strong student-teacher relationships after reviewing my observation notes.

I discussed interview data relative to emergent themes, as illustrated in Figure 1, the concept map of the interview data. Students identified both teacher and school factors as being important to them. The teacher factors related to disposition were understanding, caring, accessibility, and interest in students' lives outside of school. The teacher factors related to knowledge and skills were that teachers explain things well and follow up. Factors relating to schools were structural and cultural. The structural factors 
were small class size and clear student limitations. The cultural factors were that the school had a family environment, student accountability, and motivation systems. These factors led to changes in the participants who attended Hope Academy. The changes that students exhibited were increases in motivation, determination to succeed, and selfawareness. Following the discussion of the concept map, I reviewed individual students' perspectives as they related to each of the research questions. Chapter V includes a discussion of the findings of this study. 


\section{CHAPTER V \\ DISCUSSION}

The purpose of this study was to investigate the perspectives of students with disabilities who attend Hope Academy, a regional safe school, on their schooling experiences. I conducted 1:1 interviews with 8 students of high school age to gain their perspectives on the strengths and weaknesses of their home schools and Hope Academy. I interviewed 7 of the students on three different occasions; the last student participated in only one interview. During the interviews, student discussed factors they thought had helped and hindered their successes at their public schools and at Hope.

Prior to conducting interviews, I reviewed documents related to Hope Academy. These documents contained information about the purpose and expectations, the demographics of the school, and the curriculum offered at Hope. I also observed several different settings at Hope prior to interviewing students. These included both academic and nonacademic settings. Observations of the students and staff in their educational settings were important because I was able to confirm the findings of student interviews using observation data.

This chapter includes a discussion of this study's findings as I described in Chapter IV. Teacher factors and school factors affected students' perspectives of their educational experiences and led to changes in students. In addition to addressing these emergent themes, I address each of the study's research questions related to these themes. As stated in Chapter IV, I combined Research Questions 1 and 3 to reflect students' 
voices and interpretations. I also discuss in this chapter the conceptual framework of this study, limitations of the study, implications for practice, and recommendations for future research.

\section{Key Findings Related to Teacher Factors}

In this study, students emphasized the importance of teacher factors in their overall perspectives of their schooling as well as contributors to their success or failure. All of the participants in this study identified having teachers who care, are willing to help when the students need it, and are fair as being important to their success.

\section{Teachers Who Care}

The responses of the 8 students who participated in this study underscored the importance of having teachers who cared about them as students and people. They considered this to be the most important factor in their success as they indicated that the other important factors to success stemmed from this. A number of students stated that teachers would not help them, treat them fairly, or encourage their success if those teachers did not care. Many of them felt that they had experienced uncaring teachers at their public schools prior to enrolling in Hope Academy. Black (2006) noted that many high school students feel that no one cares about them and are disconnected from their schools. That feeling was expressed repeatedly by the students in this study who stated that no one cared about them and described adult actions demonstrating that lack of caring. The caring that these students felt at Hope pervaded their interactions with adults at the school. Noddings (1992) agreed that all education is based on relationships and that authentic caring places students' welfare as paramount. 
Doyle and Doyle (2003) stated that, "All schools care about the academic performance of their students, but schools that are caring communities go beyond core content to the psychological and social well-being of their students" (p. 260). The fact that teachers cared about their lives outside of school was important to students in this study. Students talked of the participation of school staff in their court hearings and in helping the students pay school fees. One student talked about the staff at Hope helping his family when they were homeless. Financial concerns or the at-risk status of students were among the topics addressed by a number of these students. Bennett (2008) discussed the importance of teachers understanding the realities in which their students lived. I did not talk to teachers at Hope about their training; however, their actions demonstrated an understanding of poverty as one of the elements contributing to the diversity of their students (Bennett, 2008). Muller (2001) found that relationships between at-risk students and teachers were important as students expended more effort when they believed that teachers cared about them, praised their effort, and expected them to succeed.

Urban students of color. Much research on caring has focused on the importance of teacher-student relationships for students who attend urban schools and are students of color. Of the 8 students who participated in this study, 5 resided in small, urban communities and had attended large high schools prior to their enrollment in Hope Academy. Four of these students were African American. According to AntropGonzalez (2006), a school becomes a sanctuary when there are caring relationships between students and teachers, a family-like environment, psychologically and physically safe spaces, and a forum to affirm their racial or ethnic pride. In the interviews that were 
part of the current study, students identified all but the last of these as being important elements of their experiences at Hope. As Zach said, emphasizing the importance of his relationships with teachers, "This school has saved lives before.” (Zach, January 4, 2011)

This study reinforces the idea that authentic caring is important to urban students of color (Alder, 2002; Antrop-Gonzalez, 2006; Antrop-Gonzalez \& De Jesus, 2006). Prior research has indicated that specific teacher behaviors are identified by African American and Latino/a students as conveying caring. In addition to offering help and being accessible, students identified showing kindness through actions, showing interest in life outside of school, believing in their ability to succeed, and pushing them to success as teacher behaviors that conveyed caring (Garza, 2009; Howard, 2002; Knight-Diop, 2010). African American students also named teachers making school seem like home, the staff functioning like family, and teachers having high expectations for students as demonstrating teacher caring (Antrop-Gonzalez \& De Jesus, 2006; Howard, 2002). This was echoed by both African American and Caucasian students in the current study who repeatedly referred to the school staff at Hope Academy as family and noted that staff members demanded that they be successful. The alternative to high expectations for these students was offered by Curwin (2010): "Many troubled youths find a comfort zone when adults give up on them. They no longer face expectations for success, improved behavior, doing work, or trying harder" (p. 39).

Studies of African American and Latino/a students found that a culturally relevant curriculum and opportunities to express pride in one's culture were important for the academic success of these students (Antrop-Gonzalez \& De Jesus, 2006; Howard, 2002; Parsons, 2005; Shiller, 2009). These themes were not borne out in the findings of my 
study. None of the students addressed curriculum issues as being particularly important or unimportant to their success, and racial or cultural issues were not raised. Students also did not address racial or cultural issues when asked about getting along well with peers or fair treatment by school officials. This may be due to the fact that students felt a sense of commonality within the Hope community, where their differences were addressed by responsive teachers and curriculum.

Student perspectives. Alder (2002) studied the meaning of care as defined by urban middle school students. Students in Alder's study indicated that teachers' willingness to be strict, control disruptive behavior in the classroom, push students to complete work, teach to understanding, answer questions, call students' parents, and help with academic and personal problems were ways in which they demonstrated caring. In the study I conducted, students identified many of these behaviors as indicating the caring of their teachers. Strictness with academic and social behavior, helping, driving students to produce their best work, teaching in different ways until students understood, calling parents to report good and bad behavior, and knowing students personally were important to the students I interviewed. School staff calling home was an issue of particular interest to the students in my study. The majority of them mentioned that Hope Academy staff called their parents when they were not in school or had engaged in inappropriate behavior and they noted that the phone calls were a deterrent for the behavior. Although this might initially be perceived as punitive, the students in this study regarded it as a way their teachers showed their caring for the students. They noted that the teachers cared enough to figure out where they were and what they were doing. This was in contrast to staff at public schools, who students reported either did not know that students were not 
in attendance or, from the students' perspective, did not care. In another profile of student perspectives in urban schools, students also named calling home about absences as a behavior that demonstrated teachers' caring (Shiller, 2009). In Alder's (2002) and Teven's (2007) studies, as in the current study, students equated a teacher's caring with willingness to be helpful.

Cassidy and Bates (2005) focused specifically on an alternative school where they studied the perspectives of both students and adults. The students, like those who participated in the current study, had a history of suspension, expulsion, and criminal activity. The authors interviewed administrators, teachers, and students as part of the study. Administrators discussed the need to care about students' lives outside of academics. Teachers recognized their roles as more flexible than those of teachers in traditional schools, and they emphasized the importance of building relationships with students and working in the best interests of students. Students felt safe to ask for help, safe from school staff members with whom they had dysfunctional relationships, and safe to get upset if they had problems.

\section{Teachers Who are Willing to Help When Needed}

As stated in the previous section, the students in my study reinforced the literature, asserting that students equated teacher caring with accessibility (Alder, 2002; Cassidy \& Bates, 2005; Garza, 2009). In Cassidy and Bates' study, students at an alternative school were very practical in the way they defined care: "You always have help when you need it" (p. 89). The students who participated in my study agreed with this definition and with the contrast they had felt at their previous schools; they had trouble getting help and understanding, and their lack of understanding sometimes led to 
conflicts with staff members (Cassidy \& Bates, 2005). Again, like the students I interviewed, those Cassidy and Bates interviewed described their alternative school teachers as being different from other teachers.

Muller (2001) noted that teachers must convince students that they will work to help those students learn; this may be more important for at-risk than typical students. My participants asserted repeatedly that their teachers at Hope Academy would not allow them to fail, that the teachers would press them to complete assignments, and that the teachers would continue to teach in different ways until the students understood the material. Indeed, teaching to understanding and demanding students' best performance and behavior are key elements that have been identified as demonstrating teachers' caring about students (Alder, 2002; Antrop-Gonzalez, 2006; Howard, 2002; Parsons, 2001, 2005).

\section{Fair Treatment}

Chory (2007) stated that fairness is necessary for the formation of positive and productive teacher-student relationships. Students in my study all felt that they had meaningful relationships with their teachers at Hope Academy. For a number of them, this experience was significantly different from what they had experienced while attending public school. Although students asserted that they had meaningful individual relationships with staff members, they recognized that the staff cared about all of the students at Hope, even if the students did not appear to care about themselves (Shiller, 2009). This type of caring reflects an environment where individuals and groups are valued and illustrates a teacher-student relationship in which teachers are the givers and students the receivers of care (Garza, 2009). 
In Cassidy and Bates' (2005) study at an alternative school for high school students who had current or former involvement with the court system, there were no rules for behavior and the school staff did not punish students. Instead, students performed restitution and discussed with caring adults how their actions had affected the school community. Although Hope Academy did have rules for behavior and punishments when students' behavior warranted such measures, the students who participated in my study felt that their voices were heard and that they were treated fairly in the area of discipline. The students I interviewed said that they were able to share their perspectives on troublesome school situations and that there were staff members to whom they could speak about issues if needed.

Knight-Diop (2010) stated that African American students experience distinctly inferior opportunities during their educational careers. An exploration of the perceptions of African American students of their learning environments indicated that "many have expressed their displeasure with schools in ways that have only resulted in their further alienation in the form of academic underachievement, school suspension and expulsion, and myriad other implicit and explicit punitive actions" (Howard, 2002, p. 427). Even among college students, perceived unfairness predicted students' hostility and indirect aggression toward their instructors (Chory-Assad \& Paulsel, 2004). This was true of African American and Caucasian students in my study who reported verbal altercations with teachers when they did not understand instruction or materials, an inequitable application of rules and consequences, and no opportunity to express their perspectives on crisis situations. 
The students I interviewed did not make racial distinctions in their discussion of

fairness. Although some research has indicated that African American students are more likely than Caucasian students to perceive that school rules are unfair and racial climate is unfavorable (Kupchik \& Ellis, 2008; Watkins \& Aber, 2009), the students in my study did not indicate such perceptions. This was also true of their perceptions of treatment in their public schools as well as at Hope Academy.

\section{Findings on Teacher Factors: Addressing the Research Questions}

The majority of the research discussed in this section focused on teacher factors and specific student characteristics. Researchers studied African American, Latino/a, urban, and alternative schools and students. A key difference between my study and those cited in the teacher factors section was that my study focused specifically on the perspectives of students with disabilities who attended an alternative school. None of the aforementioned studies named students with disabilities as participants.

My first research question was: What are the perspectives of students enrolled in a regional safe school regarding their experiences and the effectiveness of the schooling in their home schools and regional safe school? Students equated effectiveness with success and based their overall experiences on whether or not they had been successful, both academically and behaviorally. Regarding teacher factors, all students expressed that they had better, more effective relationships with teachers at Hope Academy than they had when they attended public schools. This was consistent with research on caring schools in which teachers were caring, respectful, and responsive to student needs (Alder, 2002; Cassidy \& Bates, 2005; Garza, 2009; Parsons, 2001; Peterson \& Taylor, 2009; Sautner, 2008; Thurston \& Berkeley, 1998). Students emphasized teacher factors heavily 
in assessing their success, and they credited their abilities to correct their academic trajectories to caring teachers at Hope. All students agreed that at Hope they had teachers who were more caring, fairer, and more willing and better able to provide students the help they needed than their teachers in public school (Cassidy \& Bates, 2005).

The second research question was: What are the perspectives of students enrolled in a regional safe school regarding strengths and weaknesses of the services and programming received at their home schools and regional safe school? Students did not address this in their discussion of teacher factors.

My third research question was: What do students identify as the key elements to their success in school, and what are their comparative perspectives on how their home schools and regional safe school address those elements? Students addressed this question in their comparison of teacher factors in their home schools and at Hope Academy. Related to teachers, key elements the students identified in this study included a caring demeanor, willingness to help students when they needed help, interest in students' lives outside of school, treating students fairly, holding students to high standards, and demanding students' best performance. All students weighted these factors in favor of the teachers at Hope. This is consistent with research emphasizing the relationships that teachers in alternative schools build with their students and the expression that their experiences at an alternative school were more positive than those at their public schools (Cassidy \& Bates, 2005).

\section{Key Findings Related to School Factors}

In many ways, students in my study linked teacher and school factors that were important to their success. For example, a number of them cited the fact that the classes 
were small as one of the reasons that they could get more help from their teachers. They also identified important structural and cultural factors as contributing to their success at Hope Academy.

\section{Structure}

Hope Academy was a significantly smaller school than the public schools that any of the students had attended. Although there have been disagreements about the benefits of small schools for students (Biddle \& Berliner, 2002), advocates argue that small schools can help reduce violence, improve student attendance and attitudes, raise student achievement, and increase equity (Kafka, 2008). Another study found that the minimal benefits were better for start-up small schools than for large schools that had been converted to small schools (Shear et al., 2008). The students in my study indicated that in the smaller environment it was easier for school staff to know where students were at all times and harder for students to hide in unsupervised areas of the school.

Small classes have yielded benefits in student achievement; however, research has primarily focused on small classes in early grades (Biddle \& Berliner, 2002). These studies have indicated that students make the largest gains in small classes in the early grades and that the effects increase with each year the students are exposed to those classes, that gains are larger in classes of fewer than 20 students, and that gains are retained through middle and high school. Evidence indicates that the gains may be greater for students who belong to traditionally disadvantaged groups (Biddle \& Berliner, 2002). Two large-scale projects in Tennessee and Wisconsin have contributed to the data supporting the gains made by students in small classes in the early grades. Project STAR (Student Teacher Achievement Ratio) tracked Tennessee students randomly assigned to 
small or regular classrooms for 4 years and found cumulative effects on their academic achievement through third grade (Nye, Hedges, \& Konstantopoulos, 2001). All students benefitted from participation in the small classes; however, there was only weak evidence that the achievement gap was reduced for students who participated in Project STAR (Konstantopoulos \& Chung, 2009). Wisconsin schools that participated in the Student Achievement Guarantee in Education (SAGE) program reported teachers knew individual students better, teachers enjoyed their jobs more, and there were classrooms with fewer discipline problems (Zahorik, 1999).

There is less supporting evidence for the benefits of small classes for older students. Biddle and Berliner (2002) noted that gains may not have been shown or that evidence is inconclusive. Students in my study asserted that they were performing better academically and socially because of small classes. They were able to ask questions, have more one-on-one time with teachers, and have individualized instruction if needed. Deutsch (2003) asserted that it was a myth that class size matters less in high school classes and that research simply has not addressed the benefits of small class size for students after third grade.

Several reasons have been offered to explain why small classes are beneficial: students were more engaged (Biddle \& Berliner, 2002; Deutsch, 2003); there were fewer classroom management issues (Biddle \& Berliner, 2002; Deutsch, 2003; Finn, Pannozzo, \& Achilles, 2003, Holloway, 2002; Zahorik, 1999); there were more opportunities for individualized attention from the teacher (Biddle \& Berliner, 2002; Deutsch, 2003); students were more engaged (Deutsch, 2003; Finn et al., 2003); teacher morale was better (Biddle \& Berliner, 2002; Deutsch, 2003; Finn et al., 2003; Zahorik, 1999); and students 
participated more frequently (Biddle \& Berliner, 2002; Finn et al., 2003). Reports from the students who participated in my study confirmed these benefits. They talked about there being fewer fights or discipline issues at Hope Academy than in public school, more one-one-one time, the fact that their teachers wanted to work with them even though they were the "bad" kids, and that they always had opportunities to ask questions when needed.

Researchers have agreed that small classes without changes in instructional practices would not be effective, that teachers do not often make changes in their instructional practices, and that the professional development needed for success may be overlooked (Finn, 2002; Finn et al., 2003; Holloway, 2002). This conflicts with the benefits of small classes as reported by the students I interviewed. They reported that teachers may have started out with one instructional strategy, but the teachers would try different methods until they identified one that helped the students with whom they were working. It seemed that the teachers at Hope were persistent in teaching students until the students realized academic success. This reflects what I witnessed during observations. Teachers were responsive to students' needs, whether those needs were academic or behavioral.

\section{Culture}

Small schools are most effective when they are created by and for the community in which they are located (Antrop-Gonzalez \& De Jesus, 2006). Hope Academy was established as a regional safe school, not a community-based school. It did not specifically address the mission or needs of any single community group and educated students from a number of surrounding communities, some of which had conflicting cultures. 
Hope had created its own culture that encouraged the involvement of families and student accountability.

School size alone is not enough to address students' needs; big-school pedagogy in a small setting will continue to be ineffective for many students (Antrop-Gonzalez \& De Jesus, 2006). The roles and relationships of teachers and administrators regarding students were part of the environment that was created at Hope. The information that students expressed about caring teachers and staff was important not only to individual relationships but because it created a caring environment and culture for the school. Students shared that they expected teachers at Hope to care for them and expect them to be successful, which was significantly different from their expectations regarding their public schools, where they sometimes felt invisible. Meaningful student-teacher relationships and high academic expectations complemented the creation of small learning communities in a study of small schools in New York City (Knight-Diop, 2010). In this study, students were aware of the caring acts that teachers performed toward them, and the author of the study offered small, caring school communities as a way to increase the achievement of African American students.

Students in Shiller's (2009) study said that it was comforting that at a small school the staff members were very understanding of different circumstances in their lives. Students in my study agreed, and reported that the needs of their families for food, shelter, and financial assistance were sometimes addressed by Hope personnel. My student interviewees also related that school staff would call their parents to keep them involved in school happenings. 
Wasley (2002) asked school-within-a-school students why they did so well, and they said that their teachers, "Dog us every day. They're relentless. They call our parents. They really care whether we get our work done. There's no hiding in this school" (p. 10). Several students at Hope Academy reported the same behavior from teachers and staff. They described nagging, reminding, and redirecting until tasks were complete, and asking students to stay after school if work was incomplete. Although students in this study demonstrated self-awareness and internal locus of control, I believe that teachers at Hope recognized that students continued to have a need for external motivation and support from caring adults. Students recognized that their teachers' insistence on success was a sign of the depth of caring that the teachers felt toward them.

\section{Findings on School Factors: Addressing the Research Questions}

The majority of the research discussed in this section focused on structural and programmatic factors that students identified during interviews. Researchers studied small schools and classes, community links to small schools, and small school pedagogy. A key difference between my study and those cited in the school factors section was that my study focused specifically on the perspectives of students with disabilities who attended an alternative school. Study participants in the research cited were not specifically students with disabilities but some of the studies addressed students in alternative schools.

My first research question was: What are the perspectives of students enrolled in a regional safe school regarding their experiences and the effectiveness of the schooling in their home schools and regional safe school? As stated previously, students equated effectiveness with success and based their overall experiences on whether or not they had 
been successful, both academically and behaviorally. Regarding school factors, all students expressed that they had been more successful within the small-school structure of Hope Academy than they had when they attended public schools. This was consistent with research on small schools and classes in which students benefitted from an increase of teacher time spent on instruction, increased student engagement, improved attendance, and greater equity (Finn et al., 2003; Kafka, 2008). In contrast to existent research, which has extolled the benefits of small classes during early elementary school but minimally addressed the benefits of small classes during the high school grades (Biddle \& Berliner, 2002; Konstantopoulos \& Chung, 2009; Nye et al., 2001), all students in this study asserted the importance of small classes to their success. The students in my study also agreed with the participants in Shiller's (2009) and Wasley's (2002) studies. All of these students linked the small size of the school with the staff members' willingness to understand and support the difficult circumstances in their lives while pressing them to improve themselves.

The second research question was: What are the perspectives of students enrolled in a regional safe school regarding strengths and weaknesses of the services and programming received at their home schools and regional safe school? The factors that students discussed relative to strengths and weaknesses of services were not closely linked with their success. Students discussed opportunities related to coursework that they had missed by not attending their public schools but also discussed opportunities, particularly those for credit recovery and vocational opportunities, which had been provided to them at Hope Academy. A number of students talked about their special education resource 
class at Hope, but the importance of that class to the student was linked to teacher rather than school factors.

My third research question was: What do students identify as the key elements to their success in school, and what are their comparative perspectives on how their home schools and regional safe school address those elements? Students addressed this question in their comparison of school factors in their home schools and at Hope Academy. Related to school factors, key elements the students identified in this study included a small school, small classrooms, and a culture that set high expectations for them. All students weighted these factors in favor of the teachers at Hope.

\section{Key Findings Related to Changes in Students}

\section{Motivation}

The students who participated in this study repeatedly talked of their increased motivation to succeed academically since enrolling in Hope Academy. This idea was posited by Jones (2008) who noted that motivation was a changeable condition that teachers have the ability to affect with their behavior and communication with students both inside and outside the classroom. The author noted that out-of-class supports influenced students' motivation to learn and be academically successful. As stated in a previous section, the authentic caring of teachers was important to the students in my study, and a number of them equated caring with teachers' concern for their lives both as students and people. This involvement in students' lives can have a positive effect on student achievement when teachers build meaningful relationships with their students (Flynt \& Brozo, 2009). 
The importance of the role of teacher-student relationships in student motivation has been emphasized in several studies of elementary, secondary, and college students (Hufton, Elliott, \& Illushin, 2003; Montalvo, Mansfield, \& Miller, 2007; Pogue \& AhYun, 2006; Rugutt \& Chemosit, 2009; Seifert, 2004; Van Petegem, Aelterman, Rosseel, \& Creemers, 2006; Wilson, 2006). Teachers recognized the importance of their relationships with students as sources of student motivation and noted that when students liked and felt respected by teachers, those students were willing to work harder (Hufton et al., 2003; Rugutt \& Chemosit, 2009; Wilson, 2006). Students echoed this sentiment in a study by Montalvo et al. (2007).

Van Petegem et al. (2006) studied school and classroom environments that were conducive to increased or decreased motivation and cited teacher-student relationships as a contributing factor. The students in the current study discussed the importance of teachers caring about them even when they did not care about themselves. This contributed to their goal setting, specifically their motivation to graduate from high school. In addition, I observed and students expressed in interviews that the environment at Hope was student centered, and they felt that they could get help from staff members with academics and other issues.

Students in this study were also motivated by their success at Hope. None of them expressed that they had been academically successful, and all agreed that they were performing better at Hope. When students experience success, their confidence is maintained or rebuilt, leading to increased motivation (Stiggins, 1999). Many students admitted that they would not have graduated from high school if they had continued at their public schools rather than attending Hope. They all expressed the desire to 
graduate, had set graduation as a goal, and knew what they needed to do to attain that goal. The setting of and working toward challenging academic goals was a sign of students' motivation (Meece, Anderman, \& Anderman, 2006; Seifert, 2004),

\section{Determination to Succeed}

The students who participated in this study had a determination to succeed, which they defined as graduating from high school. They felt obligated to care about their future and their success since their teachers did. Eisenman (2007) stated that teaching selfdetermination skills can reduce students' risk-taking behavior and increase their persistence in school. The self-determination skills that the students in this study possessed related both to their motivation to succeed, previously discussed, and their self-awareness, discussed in the following section. Students experienced changed attitudes about school, perceived their abilities to be successful, and recognized the role that Hope Academy staff had played in changing their perceptions about school and self (Eisenman, 2007).

\section{Self-Awareness}

The students who participated in this study took responsibility for their actions at both Hope and at their public schools. This internal locus of control means that students in this study attributed their ability to gain reinforcement to themselves rather than to others (Rotter, 1954). According to Biondo and MacDonald (1971), college students who perceived an external locus of control were more conforming and susceptible to messages attempting to influence them. In addition, students with an internal locus of control showed superior achievement compared to those with external locus of control (Smith \& Mihans, 2009; Uguak, Elias, \& Suandi, 2007). The beliefs expressed by the students in the current study, that they are responsible for and in charge of their behavior, 
contrast with what might be thought of them at first glance: They are placed at an alternative school for making poor academic and behavioral choices, yet they claim responsibility for their choices.

This is in partial contrast to the phenomenon identified by Lao and Bolen (1984), that when students received feedback about their success, they attributed performance to ability but when they received feedback about failure, they attributed it to the difficulty of the task. The students in my study had failed numerous times before enrolling in Hope; however, they had received much positive feedback since their arrival at Hope. It is possible that the positive feedback received at Hope allowed these students to acknowledge both their successes and failures. Also interesting is the contrast between the internal locus of control demonstrated by these students and the fact that students with learning disabilities tend to be more external in their orientation than their same-age peers without disabilities (Lewis \& Lawrence-Patterson, 1989). The importance of acknowledging students' success and teaching students to recognize their own success and achievement as a result of their behavior (Klassen \& Lynch, 2007; Lewis \& Lawrence-Patterson, 1989; Swanson, 1989) proved essential in the success of the students in my study. These students had also recognized that their own effort will determine their success; that “learning will not be possible without efforts to learn" (Uguak et al., 2007, p. 126).

Although students recognized their roles in their past and future behavior, they may have overestimated their abilities to be successful without the structure of the alternative setting. Klassen and Lynch (2007) agreed that academic confidence contributed to achievement, but found that students with learning disabilities tended to overestimate their ability to be successful on academic tasks. The responses of the students in my 
study reinforced this finding. They all acknowledged some difficulty with academics, but most asserted that they could do the tasks presented if they tried harder. However, although they thought that they could be successful if they tried, the students in my study were also able to list their strengths and weaknesses, qualities of which the students in Klassen and Lynch's study were unaware.

\section{Conceptual Framework}

I began this study by establishing a conceptual framework as the lens through which research questions, data collection and analysis, and findings would be viewed. The Least Restrictive Environment (LRE) mandate requires school districts to develop a continuum of placements where students with disabilities might be educated, making efforts to educate students with disabilities in the same educational environments as their peers without disabilities. As reviewed in Chapter I, the concept of LRE has changed with legislation, advocacy efforts, case law, and research; however, it continues to be a guiding tenet of special education law and a right of students with disabilities.

My study participants who disclosed their disabilities said that they had learning disabilities (LD). In 2007, nationally and in the state of Illinois, this group was educated in separate facilities at a rate of $1.3 \%$ and $1.0 \%$, respectively. However, there is a general consensus among researchers that students with LD should spend the majority of their time in the general education classroom (Klingner, Vaughn, Hughes, Schumm, \& Elbaum, 1998; Marston, 1997; McLeskey, Hoppey, Williamson, \& Rentz, 2004).

Although Hope Academy was a general education school, it was also an out-ofdistrict placement for all of the students in this study, which made it more restrictive than the students' home schools. Hope Academy did not provide more intensive special 
education services to address students' disabilities than did their public high schools. In addition, all students in this study were placed at Hope as a result of expulsion or multiple suspensions. These placements were not made as a result of the students' educational needs stemming from their disabilities.

Therefore, it can be concluded that Hope Academy was not the LRE for these students. The needs dictated by their disabilities would have necessitated services that could have been provided in a public school setting. The students were placed in a more restrictive environment for reasons related to discipline rather than to their educational needs. However, by the students' own judgments, they were unsuccessful at public school and had not benefitted from the services that were provided to them. All of the students in this study recognized that they were much more successful and needed the structure that was provided at Hope. The findings of this study support an argument that the LRE based on disability-related needs alone may not always be the best placement for some students with disabilities. It is possible that students' other needs, unrelated to their disabilities, should dictate which placements are most appropriate. The individual needs of the students who participated in this study dictated placement at Hope Academy, the educational environment which would most likely facilitate their success.

\section{Limitations of the Study}

This study had several limitations. The first was that it focused on students at one regional safe school in a small urban community. This limits the generalization of the data to other regional safe school or alternative school settings or to other students with disabilities who are educated in these settings. The students educated at this school were students with high incidence disabilities who were placed at the school because of 
discipline issues rather than needs defined through their Individualized Education Programs (IEPs).

A second limitation of this study was that it did not examine students' IEPs and compare services that students received at the regional safe school and at their public schools. Since the purpose of the study was to examine student perceptions, there was no attempt to verify the intensity of services at the two schools that each student attended.

Further, this study should be viewed as encompassing student perspectives at a given point in time. Their behavior during the one-on-one interviews may not have been representative of the behavior they generally exhibit at school. This limitation was addressed through multiple interviews with all but one of the students who participated in the study. Although new information was gleaned from each interview, I also reviewed the perspectives that students had expressed during prior interviews.

An additional limitation of this study was the qualitative nature of the data and its analysis. Researcher bias was possible in the data analysis process as potential themes and codes were identified. To address the possibility of researcher bias, another researcher with experience in qualitative methodology independently coded each interview. The two researchers then discussed the codes that each had identified and reached consensus on the codes and concept map that represented the findings of the study.

\section{Implications for Practice}

The findings of this study have implications for practice for both public school and alternative school educators and systems. This should begin with close attention to and examination of the elements that students named as being essential to their success in school. Implications include attending to teacher factors and school factors, most notably 
teachers who care, are accessible, and treat students fairly and a school environment that is well-structured.

For public school educators, there is a need to attend to the teacher and school factors that students noted as being lacking in their public schools. This begins with teachers who demonstrate authentic caring toward students. All students in this study identified teachers with whom they had strong relationships at Hope; however, some of the students struggled to establish relationships with their public school teachers. Public schools should educate teachers on the importance of relationships for students and make efforts to identify those students for whom a strong teacher-student relationship might be especially vital. Both public and alternative schools should regard teacher-student relationships in the manner of Hope Academy, recognizing that students need teachers to care about them even if the students do not demonstrate caring about themselves.

Teacher accessibility was also listed as lacking in public school settings. Students related this to teacher caring and to school size. Public schools may not be able to reduce the size of their student bodies; however, communities within schools or grade-level teams may be an option to create smaller caring communities for students. Teachers might be encouraged to maintain some standard office hours, or question-and-answer time could be built into classes. For both public and alternative schools, teachers might be encouraged to engage in assessment of students' perceptions of their own learning, including strengths, weaknesses, and styles, rather than solely the content of that learning. Schools might provide support classes for students who need multiple exposures or different teaching methods in order to master academic content. In addition, students indicated a need to feel that teachers wanted rather than were obligated to help them. 
Fair treatment was important to students in this study; however, many of them noted that they had been treated fairly at public schools and at Hope. Giving students an opportunity to express their views about situations, having consequences that match offenses, and maintaining a code of conduct that is flexible to individual student needs are suggestions for ensuring that students believe they are treated fairly.

The students in this study identified a well-structured environment as being essential to their success. Again, school size contributes to the level of control that school staffs may have over their environments, but there are opportunities to address specific issues raised by the students in this study. Mechanisms by which student attendance is monitored and reported to students and parents should be in place. Follow-up should be immediate. Students should not have the opportunity to be truant without their parents being aware of the situation. In addition, students who are truant should be targeted for specific interventions that might include time with teachers on specific relationshipbuilding activities or engagement in activities that will help students create connections with the school community rather than punitive consequences. Overall, schools should set up structures that embrace student differences and are designed to address individual rather than group needs and student rather than adult needs.

In addition to the implications for schools, this study may have implications for adult services or offices of disability concerns at colleges and universities. The students who participated in this study need to feel valued and cared about in order to produce their best work. Mentoring or check-in systems could be incorporated as part of the adult services and university systems in order to ensure that students feel a sense of belonging in their communities. 


\section{Recommendations for Future Research}

The completion of this study has led me to offer recommendations for future research in several areas. In my research, I did not study the importance of peer factors in students' perceptions and level of success at their home and alternative school settings. Although some of the students did talk about peers, they did not ascribe importance to the role of peers in either of their educational settings.

The students I interviewed in this study emphasized repeatedly the importance of teacher factors as contributors to their success at Hope. I recommend further research to identify the motivating factors for teachers who choose employment at alternative schools. What motivates them to accept initially their teaching positions, and why do they choose to continue teaching in these potentially difficult settings? In addition, further research should focus on what professional development is needed or recommended by teachers at alternative schools to ensure their success and retention.

School factors also played a role in the success of students in this study. Students in my study repeatedly discussed the importance of the small school and small classes. Although these students related the size of classes to both teacher and school factors, future research should also focus on the academic benefits of small classes to students in middle and high school grades. This is necessary to determine whether or not the benefits of student placement in small classes in early grades extend to middle and high school.

This study focused on the perceptions of students with disabilities who attended a regional safe school. As a study of perceptions, there was no attempt to compare the actual special education services that students had received at their home schools and 
alternative school. Services to students with disabilities may or may not have been the same at the students' public schools as they were at the regional safe school. A comparison of students' IEPs and their perceptions of their success at both settings would add insight to whether students see services or settings as contributing more to their success.

The students who participated in this study were unanimous in identifying their levels of success as being higher at the alternative school than at their public schools. Although a number of students hypothesized that they might have dropped out of school if they had continued to attend public school, they discussed attending college after completing high school at Hope. Further study should be devoted to the post-school outcomes of these students. It is unclear for them whether or not they will generalize the skills that they have learned at Hope to other educational and social settings. Positive postschool outcomes will be the true test of success for these students.

\section{Chapter Summary}

This chapter included a discussion of the major themes identified in the findings of this study. Following the discussion of findings, I presented limitations of the study. Implications for practice included the creation of caring communities in schools, strengthening of teacher-student relationships, and maintaining a school structure that is strong yet flexible enough to respond to individual student needs. Recommendations for future research included exploring the role of peers in students' assessments of their success in alternative and public schools, determining the motivating factors for teachers who choose to teach at alternative schools, studying the outcomes for students with disabilities who attend alternative schools, and analyzing the benefits of small classes for middle and high school students. 


\section{REFERENCES}

Alder, N. (2002). Interpretations of the meaning of care: Creating caring relationships in urban middle school classrooms. Urban Education, 37, 241-266. doi: $10.1177 / 0042085902372005$

Alternative Schools Research Project. (2005). Introduction [Website]. Retrieved from http://ici.umn.edu/alternativeschools/project/default.html

Antrop-Gonzalez, R. (2006). Toward the School as Sanctuary concept in multicultural urban education: Implications for small school reform. Curriculum Inquiry, 36, 273-301. doi: 10.1111/j.1467-873X.2006.00359.x

Antrop-Gonzalez, R., \& De Jesus, A. (2006). Toward a theory of critical care in urban small school reform: Examining structures and pedagogies of caring in two Latino community-based schools. International Journal of Qualitative Studies in Education, 19, 409-433. doi: 10.1080/09518390600773148

A.S. v. Five Town Community School District, 513 F.3d 279. ( $1^{\text {st }}$ Cir. Jan. 18, 2008).

Atkins, R., Bullis, M., \& Todis, B. (2005). Converging and diverging service delivery systems in alternative education programs for disabled and non-disabled youth involved in the juvenile justice system. Journal of Correctional Education, 56, 253-285. Retrieved from http://www.ceanational.org

Atkins, T., Hohnstein, S., \& Roche, V. (2008). Perceptions of their new school: Students with and without disabilities changing to an alternative and charter school. Journal of School Choice, 2(1), 47-65. doi: 10.1080/15582150802007390

Barrett, E. J. (2003). Evaluating education reform: Students' views of their charter school experience. The Journal of Educational Research, 96, 351-358. doi: 10.1080/00220670309596618

Bennett, M. M. (2008). Understanding the students we teach: Poverty in the classroom. The Clearing House, 81(6), 251-256. doi: 10.3200/TCHS.81.6.251-256.

Berg, B. L. (2004). Qualitative research methods for the social sciences. Boston, MA: Pearson Education Inc.

Biddle, B. J., \& Berliner, D. C. (2002, February). Small class size and its effects. 
Educational Leadership, 12-23. Retrieved from

http://www.eric.ed.gov/ERICWebPortal/detail?accno=EJ640898

Black, S. (2006). The power of caring to help kids adjust and achieve is now documented. American School Board Journal, 193, 46-49. Retrieved from http://www.eddigest.com/html/contentsdec.html

Board of Education of the Hendrick Hudson Central School District, Westchester County v. Rowley, 458 U.S. 176. (1982).

Board of Education of Murphysboro Community Unit School District No. 186 v. Illinois State Board of Education and M.S., 41 F.3d 1162. ( $7^{\text {th }}$ Cir. 1994).

Bogdan, R. C., \& Biklen, S. K. (2007). Qualitative research for education: An introduction to theories and methods. Boston, MA: Pearson Education Inc.

Bogdan, R., \& Taylor, S. J. (1975). Introduction to qualitative research methods. New York, NY: John Wiley \& Sons.

Bratter, T. E., Bratter, C. J., Coiner, N. L., Kaufman, D. S., \& Steiner, K. M. (2006). Motivating gifted, defiant, and unconvinced students to succeed at the John Dewey Academy. Ethical Human Psychology and Psychiatry, 8(1), 7-16. doi: 10.1891/ehpp.8.1.7

Brown v. Board of Education, 347 U.S. 483. (1954).

Brown, L. H., \& Beckett, K. S. (2007). Parent involvement in an alternative school for students at risk of educational failure. Education and Urban Society, 39, 498-523. doi: 10.1177/0013124507301579

Brown, L., Schwarz, P., Udvari-Solner, A., Kampschroer, E., Johnson, F., Jorgensen, J., \& Grunewald, L. (1991). How much time should students with severe disabilities spend in regular classrooms and elsewhere? Journal of the Association for Persons with Severe Handicaps, 16, 39-47. Retrieved from http://eric.ed.gov/ERICWebPortal/detail?accno=EJ429977

B.S. v. Placentia-Yorba Linda Unified School District, 2009 , No. 07-56477. $\left(9^{\text {th }}\right.$ Cir. 2009).

Bullock, L. M. (2007). Introduction to the special issue: Ensuring student success through alternative schools. Preventing School Failure, 51(2), 3-4. doi: 10.3200/PSFL.51.2.3-4

California Codes, Education Code, Section 56360-56369. (n.d.). Retrieved from http://www.leginfo.ca.gov/index.html

Campbell, J. M., Ferguson, J. E., Herzinger, C. V., Jackson, J. N., \& Marino, C. (2005). Peers' attitudes toward autism differ across sociometric groups: An 
exploratory investigation. Journal of Developmental and Physical Disabilities, 17, 281-298. doi: 10.1007/s10882-005-4386-8.

Carver, P. R., Lewis, L., \&Tice, P. (2010). Alternative schools and programs for public school students at risk for educational failure: 2007-2008. (NCES 2010-026). U.S. Department of Education. Washington, DC: National Center for Education Statistics. Retrieved from http://nces.ed.gov/pubsearch/pubsinfo.asp?pubid=2010026

Cassidy, W., \& Bates, A. (2005). "Drop-outs" and "Push-outs": Finding hope at a school that actualizes the ethic of care. American Journal of Education, 112(1), 66-102. Retrieved from http://www.jstor.org/stable/10.1086/444524

Castleberry, S. E., \& Enger, J. M. (1998). Alternative school students' concepts of success. NASSP Bulletin, 82, 105-111. doi: 10.1177/019263659808260215

Charmaz, K. (2003). Grounded theory: Objectivist and constructivist methods. In N. K. Denzin \& Y. S. Lincoln (Eds.), Strategies of qualitative inquiry ( $2^{\text {nd }}$ ed., pp. 440-444). Thousand Oaks, CA: Sage Publications, Inc.

Chory, R. M. (2007). Enhancing student perceptions of fairness: The relationship between instructor credibility and classroom justice. Communication Education, 56, 89-105. doi: 10.1080/03634520600994300

Chory-Assad, R. M., \& Paulsel, M. L. (2004). Classroom justice: Student aggression and resistance as reactions to perceived unfairness. Communication Education, 53, 253-273. doi: 10.1080/0363452042000265189

Christina McComish v. Underwood Public Schools, No. 1:06cv65. (D. N.D. Mar. 6, 2008).

Corey H. v. Board of Education of the City of Chicago, No. 92 C 3409. (N.D. Il. 1998).

Council for Exceptional Children. (1995). Inclusion: What does it mean for students with learning disabilities. Reston, VA: Author.

Creswell, J. W. (2007). Qualitative inquiry and research design: Choosing among five approaches. Thousand Oaks, CA: Sage Publications, Inc.

Creswell, J. W. (2008). Educational research: Planning, conducting, and evaluating quantitative and qualitative research. Upper Saddle River, NJ: Pearson.

Curwin, R. L. (2010). Motivating urban youth. Reclaiming Children and Youth, 19(1), 35-39. Retrieved from http://web.ebscohost.com.proxy.lib.ilstu.edu/ehost/

D’Angelo, F., \& Zemanick, R. (2009). The Twilight Academy: An alternative education program that works. Preventing School Failure, 53, 211-218. Retrieved from http://www.heldref.org 
deGruy, E. J. (2009). Student perceptions of therapeutic day and public school experiences. Unpublished manuscript.

Deno, E. (1970). Special education as developmental capital. Exceptional Children, 37, 229-237.

Denzin, N. K., \& Lincoln, Y. S. (2003). Strategies of qualitative inquiry. Thousand Oaks, CA: Sage Publications, Inc.

Deutsch, F. M. (2003). How small classes benefit high school students. NASSP Bulletin, 87, 35-44. doi: 10:1177/019263650308763504

Doyle, L. H., \& Doyle, P. M. (2003). Building schools as caring communities. The Clearing House, 76, 259-261. doi: 10.1080/00098650309602016

Dukes, C., \& Lamar-Dukes, P. (2009). Inclusion by design. Teaching Exceptional Children, 41(3), 16-23. Retrieved from http://eric.ed.gov/ERICWebPortal/detail?accno=EJ842560

Dunn, L. M. (1968). Special education for the mildly retarded - Is much of it justifiable? Exceptional Children, 35, 5-22.

Education for All Handicapped Children Act of 1975, 20 U.S.C. 1400 et seq., Pub. L. No. 94-142.

Estell, D. B., Jones, M. H., Pearl, R., Van Acker, R., Farmer, T. W., \& Rodkin, P. C. (2008). Peer groups, popularity, and social preference. Journal of Learning Disabilities, 41(1), 5-14. doi: 10.1177-0022219407310993

Estes, M. B. (2001). Choice for all?: Charter schools and students with disabilities (Doctoral dissertation). Retrieved from http://digital.library.unt.edu/

Estes, M. B. (2004). Choice for all? The Journal of Special Education, 37, 257-267. doi: 10.1177/00224669040370040501

Estes, M. B. (2009). Charter schools and students with disabilities: How far have we come? Remedial and Special Education, 30, 216-224. doi:10.1177/0741932508315647

Etscheidt, S. (2006). Seeking an interim alternative education placement for dangerous or disruptive students with disabilities: Four burdens for the school district to meet. American Secondary Education, 34(2), 67-84.

Retrieved from http://www3.ashland.edu/ase

Farrell, P., \& Polat, F. (2003). The long-term impact of residential provision for pupils with emotional and behavioural difficulties. European Journal of Special Needs Education, 18, 277-292. doi: 10.1080/0885625032000120189 
Finn, J. D. (2002, March). Small classes in American schools: Research, practice, and politics. Phi Delta Kappan, 551-560. Retrieved from http://www.classsizematters.org/finn_2002.pdf

Finn, J. D., Pannozzo, G. M., \& Achilles, C. M. (2003). The "Why's” of class size: Student behavior in small classes. Review of Educational Research, 73, 321368. doi: 10.3102/0034654307003321

Flynt, E. S., \& Brozo, W. G. (2009). It's all about the teacher. The Reading Teacher, 62, 536-538. doi: 10.1598/RT.62.6.8

Frederickson, N. L., \& Furnham, A. F. (2004). Peer-assessed behavioural characteristics and sociometric rejection: Differences between pupils who have moderate learning difficulties and their mainstream peers. British Journal of Educational Psychology, 74, 391-410. doi: 10.1348/0007099041552305

Fuchs, D., \& Fuchs, L. S. (1994). Inclusive schools movement and the radicalization of special education reform. Exceptional Children, 60, 294-309. Retrieved from http://web.ebscohost.com.proxy.lib.ilstu.edu/ehost/

Gable, R. A., Bullock, L. M., \& Evans, W. H. (2006). Changing perspectives on alternative schooling for children and adolescents with challenging behavior. Preventing School Behavior, 51(1), 5-9. doi: 10.3200/PSFL.51.1.5-9

Gagnon, J. C., \& Leone, P. E. (2006). Elementary day and residential schools for children with emotional and behavioral disorders: Characteristics of educators and students. Education and Treatment of Children, 29, 51-78. Retrieved from http://educationandtreatmentofchildren.net/

Gagnon, J. C., \& McLaughlin, M. J. (2004). Curriculum, assessment, and accountability in day treatment and residential schools. Exceptional Children, 70, 263-283. Retrieved from http://www.cec.sped.org

Garza, R. (2009). Latino and white high school students' perceptions of caring behaviors: Are we culturally responsive to our students? Urban Education, 44, 297-321. doi: 10.1177/0042085908318714

Gelder, N. V., Sitlington, P. L., \& Pugh, K. M. (2008). Perceived self-determination of youth with emotional and behavior disorders: A pilot study of the effect of different educational environments. Journal of Disability Policy Studies, 19, 182-190. doi: 10.1177/1044207308314952.

General Laws of Massachusetts, Part I, Title XII, Ch.69 § 1N. (2010). Retrieved from http://www.mass.gov/legis/laws/mgl/69-1n.htm

Ghory, W. J., \& Sinclair, R. L. (1978, March). Views from the margins: Student perceptions of educational environments in public alternative high schools. 
Paper presented at the National Conference of the American Educational Research Association, Toronto, Canada.

Glover, D., \& Law, S. (2004). Creating the right learning environment: The application of models of culture to student perceptions of teaching and learning in eleven secondary schools. School Effectiveness and School Improvement, 15, 313-336. doi: 10.1080/09243450512331383232

Gold, J., \& Reisman, J. M. (1970). An outcome of a day treatment unit school in a community mental health center. Retrieved from ERIC database. (ED039590).

Gorney, D. J., \& Ysseldyke, J. E. (1993). Students with disabilities' use of various options to access alternative schools and area learning centers. Special Services in the Schools, 7(1), 125-143. doi: 10.1300/J008v07n01_08

Hardman, M. L., Egan, M. W., \& Drew, C. J. (2008). Human exceptionality. Boston, MA: Allyn and Bacon.

Harrisburg Project. (2010). Private facility search. Retrieved from http://www.hbug.k12.il.us/pfs/default.wcs

Heath, N. L., Petrakos, H., Finn, C. A., Karagiannakis, A., McLean-Heywood, D., \& Rousseau, C. (2004). Inclusion on the final frontier: A model for including children with emotional and behavior disorders (E/BD) in Canada.

International Journal of Inclusive Education, 8, 241-259. doi: 10.1080/1360311042000216910

Hendley, S. L. (2007). Use positive behavior support for inclusion in the general education classroom. Intervention in School and Clinic, 42, 225-228.

Retrieved from http://www.proedinc.com/

Hockenbury, J. C., Kauffman, J. M., \& Hallahan, D. P. (1999-2000). What is right about special education? Exceptionality, 8(1), 3-11.

doi: 10.1207/S15327035EX0801_2

Holloway, J. H. (2002, February). Do smaller classes change instruction? Educational Leadership, 91-92. Retrieved from http://eric.ed.gov/ERICWebPortal/detail?accno=EJ640911

Honig v. Doe, 484 U.S. 305. (1988).

[Hope Academy (pseudonym)]. (2010). FY 2010 End Year Report. City (not to be revealed), State (not to be revealed): Author.

Howard, T. C. (2002). Hearing footsteps in the dark: African American students' descriptions of effective teachers. Journal of Education for Students Placed at Risk, 7, 425-444. Retrieved from http://eric.ed.gov/ERICWebPortal/detail?accno=EJ658536 
Hufton, N. R., Elliott, J. G., \& Illushin, L. (2003). Teachers' beliefs about student motivation: Similarities and differences across cultures. Comparative Education, 39, 367-389. doi: 10.1080/0305006032000134427

Humphrey, N. (2009). Including students with attention-deficit/hyperactivity disorder in mainstream schools. British Journal of Special Education, 36(1), 19-25. Retrieved from http://web.ebscohost.com.proxy.lib.ilstu.edu/

Illinois Regional Safe Schools Program. (2006). FY06 Summary of Findings. Retrieved from http://www.isbe.state.il.us/research/htmls/rssp.htm

Illinois School Code, 105 ILCS 5 13. (2009).

Illinois State Board of Education. (2008). 2007-2008 Annual State Report on Special Education Performance. Retrieved from http://www.isbe.state.il.us/speced/pdf_reports/annual_performance_report07-08.pdf

Individuals with Disabilities Education Act of 1990, U.S.C. 1400, Pub. L. No. 101-476.

Individuals with Disabilities Education Act of 1997, U.S.C. 1400, Pub. L. No. 105-17.

Individuals with Disabilities Education Improvement Act of 2004, 20 U.S.C. 1400, Pub. L. No. 108-446.

Iowa Code, Title VII, Sub 6, Ch. 280 \$ 280.19A. (2009). Retrieved from http://search.legis.state.ia.us/

Jahnukainen, M., \& Helander, J. (2007). Alternative vocational schooling for the dropped-out: Students' perceptions of the Activity School of East Finland. European Journal of Special Needs Education, 22, 471-482. Retrieved from http://www.tandf.co.uk/journals/default.html

James and Lee Ann D. v. Board of Education of Aptakisic-Tripp Community Consolidated School District, 642 F. Supp. 2d 804 (E.D. Il. 2009).

Johnson, D. (2006). Listening to the views of those involved in the inclusion of pupils with Down's syndrome into mainstream schools. Support for Learning, 21(1), 24-29. Retrieved from http://www.blackwellpublishing.com/jnl_default.asp

Jones, A. C. (2008). The effects of out-of-class support on student satisfaction and motivation to learn. Communication Education, 57, 373-388. doi: $10.1080 / 03634520801968830$

Kafka, J. (2008, September). Thinking big about getting small: Ideological genealogy of small-school reform. Teachers College Record, 110, 1802-1836. http://www.tcrecord.org/Content.asp?ContentId=15168 
Katsiyannis, A., \& Williams, B. (1998). A national survey of state initiatives on alternative education. Remedial and Special Education, 19, 276-284. doi: 10.1177/074193259801900503

Kauffman, J. M. (1989). The Regular Education Initiative as Reagan-Bush education policy: A trickle-down theory of education of the hard-to-teach. Journal of Special Education, 23, 256-278. doi: 10.1177/002246698902300303

Kauffman, J. M., \& Hallahan, D. P. (1990). What we want for children: A rejoinder to REI proponents. The Journal of Special Education, 24, 340-345. doi: 10.1177/002246699002400309

Kauffman, J. M., \& Lloyd, J. W. (1995). Inclusion of all students with emotional or behavioral disorders? Let's think again. Phi Delta Kappan, 76, 542-546. Retrieved from http://www.questia.com/Index.jsp

Kavale, K. A., \& Forness, S. R. (2000). History, rhetoric, and reality: Analysis of the inclusion debate. Remedial and Special Education, 21, 279-296. doi: 10.1177/074193250002100505

Kavale, K. A., \& Mostert, M. P. (2003). River of ideology, islands of evidence. Exceptionality, 11, 191-208. Retrieved from http://web.ebscohost.com.proxy.lib.ilstu.edu/

Kershaw, C. A., \& Blank, M. A. (1993, April). Student and educator perceptions of the impact of an alternative school structure. Paper presented at the annual meeting of the American Educational Research Association, Atlanta, GA.

Kleiner, B., Porch, R., \& Farris, E. (2002, September). Public alternative schools and programs for students at risk of education failure: 2000-2001 (NCES 2002004). U.S. Department of Education. Washington, DC: National Center for Education Statistics. Retrieved from http://nces.ed.gov

Kleinman, S. (1991). Field-workers' feelings: What we feel, who we are, how we analyze. In W. B. Shaffir \& R. A. Stebbins (Eds.), Experiencing fieldwork: An inside view of qualitative research (pp. 184-195). Newbury Park, CA: Sage Publications, Inc.

Klingner, J. K., Vaughn, S., Hughes, M. T., Schumm, J. S., \& Elbaum, B. (1998). Outcomes for students with and without learning disabilities in inclusive classrooms. Learning Disabilities Research \& Practice, 13(3), 153-161. Retrieved from http://www.wiley.com/bw/journal.asp?ref=0938-8982

Knight-Diop, M. G. (2010). Closing the gap: Enacting care and facilitating black students' educational access in the creation of a high school college-going culture. Journal of Education for Students Placed at Risk, 15, 158-172. doi: $10.1080 / 10824661003635192$ 
Koch, C. A. (2001, November 8). Re: Students with disabilities in Regional Safe Schools Programs [Online memo]. Retrieved from http://www.isbe.state.il.us/grants/html/regional_safe_schools.htm

Koenig, K. P., Bleiweiss, J., Brennan, S., Cohen, S., \& Siegel, D. E. (2009). The ASD Nest Program: A model for inclusive public education for students with autism spectrum disorders. Teaching Exceptional Children, 42(1), 6-13. Retrieved from http://eric.ed.gov/ERICWebPortal/detail?accno=EJ856149

Kokoszka, R., \& Drye, J. (1981). Toward the least restrictive environment: High school L. D. students. Journal of Learning Disabilities, 14(1), 22-26. doi: $10.1177 / 002221948101400110$

Konstantopoulos, S., \& Chung, V. (2009). What are the long-term effects of small classes on the achievement gap? Evidence from the lasting benefits study. American Journal of Education, 116(1), 125-54. Retrieved from http://www.jstor.org/stable/10.1086/605103

Kupchik, A., \& Ellis, N. (2008). School discipline and security: Fair for all students? Youth and Society, 39, 549-574. doi: 10.1177/0044118X07301956

Leach, D., \& Duffy, M. L. (2009). Supporting students with autism spectrum disorders in inclusive settings. Intervention in School and Clinic, 45(1), 31-37. doi: $10.0077 / 1053451209338395$

Lehr, C. A. (2004). Students with disabilities attending alternative schools: What do we know? Impact: Feature Issue on Achieving Secondary Education and Transition Results for Students with Disabilities, 16(3), Minneapolis, MN: University of Minnesota, Institute on Community Integration. Retrieved from http://cic.umn.edu/products/impact/163

Lehr, C. A., \& Lange, C. M. (2003a). Alternative schools and the students they serve: Perceptions of state directors of special education. Policy Research Brief, 14(1), 1-12. Retrieved from http://ici2.umn.edu/products/prb/141/141.pdf

Lehr, C. A., \& Lange, C. M. (2003b). Alternative schools serving students with and without disabilities: What are the current issues and challenges? Preventing School Failure, 47(2), 59-65. doi: 10.1080/10459880309604431

Lehr, C. A., Lanners, E. J., \& Lange, C. M. (2003). Alternative schools policy and legislation across the United States. Minneapolis, MN: University of Minnesota, Alternative Schools Research Project, Institute on Community Integration. Retrieved from http://ici.umn.edu/alternativeschools/

Lehr, C. A., Moreau, R. A., Lange, C. M., \& Lanners, E. J. (2004). Alternative 
schools findings from a national survey. Minneapolis, MN: University of Minnesota, Alternative Schools Research Project, Institute on Community Integration. Retrieved from http://ici.umn.edu/alternativeschools/

Lehr, C. A., Tan, C. S., \& Ysselkyke, J. (2009). Alternative schools: A synthesis of state-level policy and research. Remedial and Special Education, 30(1), 19-32. doi: $10.1177 / 0741932508315645$

Leiberman, L. M. (1992). Preserving special education...for those who need it. In W. Stainback \& S. Stainback (Eds.), Controversial issues confronting special education (pp. 13-25). Boston, MA: Allyn and Bacon.

M.R. v. Lincolnwood Board of Education, District 74, No. 93 C 0418. (N.D. Il. Feb. 1, 1994).

M.W. v. Clarke County School District, 3:06-CV-49. (2008).

MacLeod, F. (2001). Towards inclusion - our shared responsibility for disaffected pupils. British Journal of Special Education, 28, 191-194. doi: 10.1111/1467-8527.t01-1-00224

MacMillan, D. L. (1977). Mental retardation in school and society. Boston, MA: Little, Brown and Company.

Marston, D. (1997). A comparison of inclusion only, pull-out only, and combined service models for students with mild disabilities. Journal of Special Education, 30, 121-32. Retrieved from http://sed.sagepub.com/

Mason, J. (1996). Qualitative researching. London, UK: Sage Publications Ltd.

McLeskey, J., Hoppey, D., Williamson, P., \& Rentz, T. (2004). Is inclusion an illusion? An examination of national and state trends toward the education of students with learning disabilities in general education classrooms. Learning Disabilities Research \& Practice, 19(2), 109-115. doi: 10.1111/j.1540-5826.2004.00094.x

McLeskey, J., \& Pacchiano, D. (1994). Mainstreaming students with learning disabilities: Are we making progress? Exceptional Children, 60, 508-517. Retrieved from http://journals.cec.sped.org/

McLeskey, J., Skiba, R., \& Wilcox, B. (1990). Reform and special education: A mainstream perspective. The Journal of Special Education, 24, 319-325. doi: 10.1177/002246699002400306

Meece, J. L., Anderman, E. M., \& Anderman, L. H. (2006). Classroom goal structure, student motivation, and academic achievement. Annual Reviews of Psychology, 57, 487-503. doi: 10.1146/annurev.psych.56.091103.070258 
Merulla, E., \& McKinnon, A. (1982). "Stuck” on Deno's cascade. Journal of Learning Disabilities, 15, 94-96. doi: 10.1177/002221948201500207

Meyers, S. A. (2009). Do your students care whether you care about them? College Teaching, 57(4), 205-210. doi: 10.1080/87567550903218620

Miles, M. B., \& Huberman, A. M. (1994). Qualitative data analysis: An expanded sourcebook. Thousand Oaks, CA: Sage Publications, Inc.

Mills v. Board of Education of the District of Columbia, 348 F. Supp. 866. (1972).

Montalvo, G. P., Mansfield, E. A., \& Miller, R. B. (2007). Liking or disliking the teacher: Student motivation, engagement and achievement. Evaluation and Research in Education, 20(3), 144-158. doi: 10.2167/eri406.0

Moore, J. L., Henfield, M. S., \& Owens, D. (2008). African American males in special education: Their attitudes and perceptions toward high school counselors and school counseling services. American Behavioral Scientist, 51, 907-927. doi: 10.1177/0002764207311997

Muller, C. (2001). The role of caring in the teacher-student relationship for at-risk students. Sociological Inquiry, 71, 241-55. doi: 10.1111/j.1475-682X.2001.tb01110.x

Muscott, H. S. (1997). Behavioral characteristics of elementary and secondary students with emotional/behavioral disabilities in four different cascade placements. Education and Treatment of Children, 20, 336-357. Retrieved from http://eric.ed.gov/ERICWebPortal/detail?accno=EJ558207

Nevada Revised Statutes, Title 34-Education, NRS 392.4675. (2010). Retrieved from http://www.leg.state.nv.us/NRS

Nichols, S. L. (2008). An exploration of students' belongingness beliefs in one middle school. The Journal of Experimental Education, 76(2), 145-169. doi: 10.3200/JEXE.76.2.145-169

No Child Left Behind Act of 2001, 20 U.S.C. Pub. L. No. 107-110. Retrieved from http://www2.ed.gov/policy/elsec/leg/esea02/index.html

Nye, B., Hedges, L. V., \& Konstantopoulos, S. (2001). Are effects of small classes cumulative? Evidence from a Tennessee experiment. The Journal of Educational Research, 336-345. doi: 10.3102/01623737021002127

Ohio Revised Code, Title 33, Ch. 3313 \$3313.533. (2004). Retrieved from http://codes.ohio.gov/orc/3313.533

P. v. Newington Board of Education, 546 F.3d 111. (2 $2^{\text {nd }}$ Cir. 2008). 
P.A.R.C. v. Commonwealth of Pennsylvania, 334 F. Supp. 1257. (E.D. Pa. 1971).

Parsons, E. C. (2001). Using power and caring to mediate white male privilege, equality, and equity in an urban elementary classroom: Implications for teacher preparation. The Urban Review, 33, 321-338.

doi: 10.1023/A:1012296330048

Parsons, E. C. (2005). From caring as a relation to culturally relevant caring: A white teacher's bridge to black students. Equity \& Excellence in Education, 38(1), 25-34. doi: 10.1080/10665680390907884

Pennsylvania School Code, Article XIX-C (Act 30) §§1901-1905. (1997). Retrieved from http://www.portal.state.pa.us

Pogue, L. L., \& AhYun, K. (2006). The effect of teacher nonverbal immediacy and credibility on student motivation and affective learning. Communication Education, 55, 331-344. doi: 10.1080.03634520600748623

Pomeroy, E. (1999). The teacher-student relationship in secondary school: Insights from excluded students. British Journal of Sociology of Education, 20, 465482. doi: 10.1080/01425699995218

Quinn, M. M., Poirier, J. M., Faller, S. E., Gable, R. A., \& Tonelson, S. W. (2006). An examination of school climate in effective alternative programs. Preventing School Failure, 51(1), 11-17. doi: 10.3200/PSFL.51.1.11-17

Raywid, M. A. (1994). Alternative schools: The state of the art. Educational Leadership, 52(1), 26-31. Retrieved from http://eric.ed.gov/ERICWebPortal/detail?accno=EJ509876

Reynolds, M. C. (1988). A reaction to the JLD special series on the Regular Education Initiative. Journal of Learning Disabilities, 21, 352-356. doi: 10.1177/002221948802100606

Reynolds, M. C. (1989). An historical perspective: The delivery of special education to mildly disabled and at-risk students. Remedial and Special Education, 10(6), 7-11. doi: 10.1177/074193258901000604

Richard Paul E. v. Plainfield Community Consolidated School District 202, No. 07 C 6911. (N.D. Il. 2009)

Robertson, K., Chamberlain, B., \& Kasari, C. (2003). General education teachers' relationships with included students with autism. Journal of Autism and Developmental Disorders, 33, 123-130. doi: 10.1023/A:1022979108096

Rotter, J. B. (1954). Social learning and clinical psychology. New York, NY: PrenticeHall. 
Rugutt, J., \& Chemosit, C. C. (2009). What motivates students to learn? Contribution of student-to-student relations, student-faculty interaction and critical thinking skills. Educational Research Quarterly, 32(3), 16-28. Retrieved from http://eric.ed.gov/ERICWebPortal/detail?accno=EJ847453

Rutherford, R. B., \& Quinn, M. M. (1999). Special education in alternative education programs. Clearing House, 73(2), 79-81. doi: 10.1080/00098659909600152

Sadao, K. C., \& Walker, W. L. (2002). Emancipation for youth with behavior disorders and emotional disturbance: A study of student perceptions. Preventing School Failure, 46(3), 119-125. doi: 10.1080/10459880209603356

Salend, S. J., \& Duhaney, L. M. (1999). The impact of inclusion on students with and without disabilities and their educators. Remedial and Special Education, 20(2), 114-126. doi: 10.1177/074193259902000209

Saunders, J. A., \& Saunders, E. J. (2001/2002). Alternative school students' perceptions of past (traditional) and current (alternative) school environments. High School Journal, 85, 12-23. Retrieved from http://uncpress.unc.edu/journals/j-hsj.html

Sautner, B. (2008). Inclusive, safe and caring schools: Connecting factors. Developmental Disabilities Bulletin, 36(1), 135-67. Retrieved from http://eric.ed.gov/ERICWebPortal/detail?accno=EJ828951

Sava, F. A. (2000). Is Attention Deficit Hyperactivity Disorder an exonerating construct? Strategies for school inclusion. European Journal of Special Needs Education, 15, 149-157. doi: 10.1080/088562500361583

School Laws of Oklahoma, Article VIII: Alternative Education \$\$ 911-919. (2009). Retrieved from http://sde.state.ok.us/Law/LawBook/default.html

Seifert, T. L. (2004). Understanding student motivation. Educational Research, 46, $137-$ 149. doi: 10.1080/0013188042000222421

Shaffir, W. B., \& Stebbins, R. A. (1991). Experiencing fieldwork: An inside view of qualitative research. Newbury Park, CA: Sage Publications, Inc.

Shanker, A. (1994/1995). Full inclusion is neither free nor appropriate. Educational Leadership, 52(4), 18-21. Retrieved from http://web.ebscohost.com.proxy.lib.ilstu.edu

Shapiro, E. S., Miller, D. N., Sawka, K., Gardill, M. C., \& Handler, M. W. (1999). Facilitating the inclusion of students with EBD into general education classrooms. Journal of Emotional \& Behavioral Disorders, 7, 83-93. 
doi: $10.1177 / 106342669900700203$

Shear, L., Means, B., Mitchell, K., House, A., Gorges, T., Joshi, A., Smerdon, B., \& Shkolnik, J. (2008). Contrasting paths to small-school reform: Results of a 5-year evaluation of the Bill \& Melinda Gates Foundation's National High Schools Initiative. Teachers College Record, 110, 1986-2039. http://www.tcrecord.org/Content.asp?ContentId=15180

Shiller, J. T. (2009). “These are our children!” An examination of relationshipbuilding practices in urban high schools. Urban Review, 41, 461-485. doi: $10.1007 / \mathrm{s} 11256-008-0110-1$

Sinha, J. W. (2007). Youth at risk for truancy detour into a faith-based education program: Their perceptions of the program and its impact. Research on Social Work Practice, 17, 246-257. doi: 10.1177/1049731506296944

Smith, A. (2006). Access, participation, and progress in the general education curriculum in the least restrictive environment for students with significant cognitive disabilities. Research \& Practice for Persons with Severe Disabilities, 31(4), 331-337. doi: 10.5555/rpsd.31.4.331

Stainback, S., \& Stainback, W. (1992). Schools as inclusive communities. In W. Stainback \& S. Stainback (Eds.), Controversial issues confronting special education (pp. 13-25). Boston, MA: Allyn and Bacon.

Stake, R. E. (1995). The art of case study research. Thousand Oaks, CA: Sage Publications.

Stake, R. E. (2003). Case studies. In N. K. Denzin \& Y. S. Lincoln (Eds.), Strategies of qualitative inquiry (pp. 435-454). Thousand Oaks, CA: Sage Publications, Inc.

Stake, R. E. (2006). Multiple case study analysis. New York, NY: The Guilford Press. Stevie Yates v. Washoe County School District, No. 03:07-CV-00200-LRH-RJJ. (Nv. 2008).

Stiggins, R. J. (1999). Assessment, confidence, and school success. Phi Delta Kappan, 191-198. Retrieved from http://www.jstor.org/stable/20439619

Tapasak, R. C., \& Walther-Thomas, C. S. (1999). Evaluation of a first-year inclusion program. Remedial and Special Education, 20, 216-225. doi: 10.1177/074193259902000405

Teven, J. J. (2007). Teacher caring and classroom behavior: Relationships with student affect and perceptions of teacher competence and trustworthiness. Communication Quarterly, 55, 433-450. doi: 10.1080/01463370701658077

Thurston, L. P., \& Berkeley, T. R. (1998). Morality and the ethic of care: Peaceable 
rural schools, caring rural communities. Rural Special Education Quarterly, 17(2), 25-31. Retrieved from http://eric.ed.gov/ERICWebPortal/detail?accno=EJ597878

Tropea, J. L. (1987). Bureaucratic order and special children: Urban schools, 1890s1940s. History of Education Quarterly, 27(1), 29-53. Retrieved from www.jstor.org

Unruh, D., Bullis, M., Todis, B., Waintrup, M., \& Atkins, T. (2007). Programs and practices for special education students in alternative education settings. Research to Practice Brief, 6(1), Minneapolis, MN: University of Minnesota, National Center on Secondary Education and Transition, Institute on Community Integration. Retrieved from http://www.ncset.org

U.S. Const. amend V.

U.S. Const. amend XIV.

U.S. Department of Education. (2002). Characteristics of the 100 largest public elementary and secondary school districts in the United States: 2000-2001 (NCES 2002-351). Washington, DC: National Center for Educational Statistics. Retrieved from http://nces.ed.gov/pubs2002/2002351.pdf

U.S. Department of Education. (2004). Choices for parents: Question and answers on No Child Left Behind... Charter schools. Retrieved from http://www2.ed.gov/nclb/choice/charter/charter-faq.html

U.S. Department of Education, Office of Special Education and Rehabilitative Services, Office of Special Education Programs. (2009). $28^{\text {th }}$ Annual Report to Congress on the Implementation of the Individuals with Disabilities Education Act, 2006, vol. 2. Washington, D.C.

Van Acker, R. (2007). Antisocial, aggressive, and violent behavior in children and adolescents within alternative education settings: Prevention and intervention. Preventing School Failure, 51(2), 5-12. doi: 10.3200/PSFL.51.2.5-12

Van Petegem, K., Aelterman, A., Rosseel, Y., \& Creemers, B. (2006). Student perception as moderator for student wellbeing. Social Indicators Research, 83, 447-463. doi: 10.1007/s11205-006-9055-5

Vaughn, S., \& Klingner, J. K. (1998). Students' perceptions of inclusion and resource room settings. The Journal of Special Education, 32, 79-88. doi: 10.1177/002246699803200202

Vaughn, S., \& Schumm, J. S. (1995). Responsible inclusion for students with learning disabilities. Journal of Learning Disabilities, 28, 264-270 doi: $10.1177 / 002221949502800502$ 
Vergason, G. A., \& Anderegg, M. L. (1992). Preserving the least restrictive environment. In W. Stainback \& S. Stainback (Eds.), Controversial issues confronting special education (pp. 45-54). Boston, MA: Allyn and Bacon.

Visser, J., Cole, T., \& Daniels, H. (2002). Inclusion for the difficult to include. Support for Learning, 17(1), 23-26. doi: 10.1111/1467-9604.00228

Warren, C. A., \& Karner, T. X. (2010). Discovering qualitative methods. New York, NY: Oxford University Press.

Wasley, P. A. (2002, February). Small classes, small schools: The time is now. Educational Leadership, 6-10. Retrieved from http://web.ebscohost.com.proxy.lib.ilstu.edu/ehost/

Watkins, N. D., \& Aber, M. S. (2009). Exploring the relationships among race, class, gender, and middle school students' perceptions of school racial climate. Equity \& Excellence in Education, 42, 395-411. doi: 10.1080/10665680903260218

Wehmeyer, M. L., Yeager, D., Bolding, N., Agran, M., \& Hughes, C. (2003). The effects of self-regulation strategies on goal attainment for students with developmental disabilities in general education classrooms. Journal of Developmental and Physical Disabilities, 15(1), 79-91. doi: 10.1023/A:1021408405270

Wetzel, M. C., \& NcMaboe, K. A. (1997). Public and private partnership in an alternative middle school program. Preventing School Failure, 41, 179-184. doi: $10.1080 / 10459889709603290$

Wilson, J. H. (2006). Predicting student attitudes and grades from perceptions of instructors' attitudes. Teaching of Psychology, 33(2), 91-95. doi: 10.1207/s15328023top3302_2

Wolfensberger, W. (1972). The principle of normalization in human services. Toronto: National Institute on Mental Retardation.

Wright, E. B. (1999). Full inclusion of children with disabilities in the regular classroom: Is it the only answer? Social Work in Education, 21(1), 11-22. Retrieved from http://web.ebscohost.com.proxy.lib.ilstu.edu

Yell, M. Y., \& Katsiyannis, A. (2004). Placing students with disabilities in inclusive settings: Legal guidelines and preferred practices. Preventing School Failure, 49(1), 28-35. doi: 10.3200/PSFL.49.1.28-35.

Ysseldyke, J. E., Algozzine, B., \& Thurlow, M. L. (1992). Critical issues in special education. Dallas, TX: Houghton Mifflin Co. 
Zahorik, J. A. (1999, September). Reducing class size leads to individualized instruction. Educational Leadership, 50-53. Retrieved from http://eric.ed.gov/ERICWebPortal/detail?accno=EJ592919

Zigmond, N., \& Baker, J. M. (1995). Concluding comments: Current and future practices in inclusive schooling. The Journal of Special Education, 29, 245250. doi: 10.1177/002246699502900215

Zigmond, N., Kloo, A., \& Volonino, V. (2009). What, where and how? Special education in the climate of full inclusion. Exceptionality, 17, 189-204. doi: 10.1080/09362830903231986 


\section{APPENDIX A}

INITIAL INTERVIEW PROTOCOL 
Interview Questions for Regional Safe School Student

1. Tell me about yourself.

2. Tell me about your school history. [Which schools have you attended? For how long?]

3. What is your favorite part of school? [Current and/or former schools.]

4. What difficulties have you had in school? [How did your school help you with those difficulties?]

5. When did you come to your current school? How long have you been there? If you feel comfortable, can you tell me why you came to your current school?

6. Thinking about when you were in public school, what did your school day look like? [Classes, schedule, services? Did you see a social worker, psychologist, special education teacher, counselor, speech therapist?]

7. At public school, were there things that helped you to be successful that your school did? [What were they?]

8. At public school, were there things that you needed to be successful in school that your school did not provide? [What were they? Did your school do things that made you unsuccessful?]

9. What does your day look like at your current school? [Classes, schedule, services? Do you see a social worker, psychologist, special education teacher, counselor, speech therapist?]

10. At your current school, are there things that your school does that help you be successful? [What are they?]

11. At your current school, are there things that you need to be successful in school that your school does not provide? [What are they? Does your school do things that make you unsuccessful?]

12. Thinking about your current school and public school, what do you think about your relationships with staff members? [Positive/negative, essential elements, content knowledge, general relationships with students?] 
13. Do you think you were more successful as a student when you were in public school or are you more successful at your current school? [Grades, behavior, teacher relationships? Why/How?] 
APPENDIX B

SECOND INTERVIEW PROTOCOLS 
Andrea: Second Interview

1. Why do you think you have better grades here? What does Hope do to help you keep yourself maintained and out of trouble?

2. How does Hope help you have less difficulties, like fewer arguments?

3. Tell me about a good teacher relationship that you have had at East and Hope.

4. Why might make you nervous about going back to East? Do you think you're ready?

5. Why are you doing better here? How could East do the same things to help you - do they?

6. When you say you do a lot more than you did at East, what do you mean? What do you do here?

7. I'm trying to get an overall perspective of your experiences in both East and Hope. What do you think of your experience at East overall? What about at Hope?

8. You seem pretty satisfied with the progress you have made at Hope. Why do you think you have made that kind of progress?

a. Do you think you could have done better? How?

b. What did Hope provide that was essential to your progress?

c. Do you think you could have done this well at East?

d. What else did East need to do for you to do better there?

9. What are some of the things that East did really well?

a. Offer that Hope does not?

b. Opportunities that you may feel like you missed?

10. In my last interviews, students identified teachers who care, structure, fair treatment, being able to get help when they need it as key elements to their success. How did Hope address those things? How did East? 
11. What have you accomplished that you are proud of? How would this be different if you weren't at Hope?

12. How would you change Hope if you could? Do you think that would make it better or weaker? How would you change East if you could?

13. What has Hope done to make you more successful in academics, behavior, and teacher relationships?

14. Think about high school as preparing you for life. How has Hope prepared you for life? Can you think about how this might be different if you had stayed at East?

15. What is the most important thing that East / Hope has done for you? How has East / Hope helped/hindered you as a person?

Bobby: Second Interview

1. You talked last time about having more teacher time at Hope. How does that help you? What kinds of things do teachers do when they're spending time with you?

2. How do teachers at Hope explain the lesson better?

3. What does Mitchell do to help you with your difficulties in reading and math? Any issues in Intro to Business?

4. Why is it important that you can talk to the adults at Hope?

5. When you had the situation with the pocket knife at Mitchell, you said that they believed another student over you. Did you feel like you were treated fairly in that situation?

6. When you used to see the social worker at Hope, what kinds of issues did you discuss? How are you doing with those things now? 
7. When you said that Hope is worried about everybody, what do you mean? Can you give me an example?

8. Give me an example of how Mrs. (resource teacher) helps you.

9. You said that your grades were kind of shaky. How did your semester turn out?

10. Why do you think your behavior is more successful here?

11. I'm trying to get an overall perspective of your experiences in both Mitchell and Hope. What do you think of your experience at Mitchell overall? What about at Hope?

12. You seem pretty satisfied with the progress you have made at Hope. Why do you think you have made that kind of progress?

a. Do you think you could have done better? How?

b. What did Hope provide that was essential to your progress?

c. Do you think you could have done this well at Mitchell?

d. What else did Mitchell need to do for you to do better there?

13. What are some of the things that Mitchell did really well?

a. Offer that Hope does not?

b. Opportunities that you may feel like you missed?

14. In my last interviews, students identified teachers who care, structure, fair treatment, being able to get help when they need it as key elements to their success. How did Hope address those things? How did Mitchell?

15. What have you accomplished that you are proud of? How would this be different if you weren't at Hope?

16. How would you change Hope if you could? Do you think that would make it better or weaker? How would you change Mitchell if you could? 
17. What has Hope done to make you more successful in academics, behavior, and teacher relationships?

18. Think about high school as preparing you for life. How has Hope prepared you for life? Can you think about how this might be different if you had stayed at Mitchell?

19. What is the most important thing that Mitchell / Hope has done for you? How has Mitchell / Hope helped/hindered you as a person? 
Evan: Second Interview

1. Tell me a little bit more about Columbia Heights. You said that was the worst school you've been to. Why?

2. Think about your freshman year and the beginning of your sophomore year. How did you adjust to Wright after being at Hope? What went well for you? What was difficult?

3. Talk to me about the differences between teachers here and at Wright. How $\mathrm{did} /$ does each help you?

4. You said English and math were the most difficult classes for you. How did Wright and Hope help with those classes?

5. You said that you didn't do well in freshman English because you didn't like the teacher. Why is that?

6. You talked about football and sports being really important at Wright, being part of the school culture. What things are really important to the school culture at Hope?

7. I'm trying to get an overall perspective of your experiences in both Wright and Hope. What do you think of your experience at Wright overall? What about at Hope?

8. You seem pretty satisfied with the progress you have made at Hope. Why do you think you have made that kind of progress?

a. Do you think you could have done better? How?

b. What did Hope provide that was essential to your progress?

c. Do you think you could have done this well at Wright?

d. What else did Wright need to do for you to do better there?

9. What are some of the things that Wright did really well? 

a. Offer that Hope does not?
b. Opportunities that you may feel like you missed?

10. In my last interviews, students identified teachers who care, structure, fair treatment, being able to get help when they need it as key elements to their success. How did Hope address those things? How did Wright?

11. What have you accomplished that you are proud of? How would this be different if you weren't at Hope?

12. How would you change Hope if you could? Do you think that would make it better or weaker? How would you change Wright if you could?

13. What has Hope done to make you more successful in academics, behavior, and teacher relationships?

14. Think about high school as preparing you for life. How has Hope prepared you for life? Can you think about how this might be different if you had stayed at Wright?

15. What is the most important thing that Wright/ Hope has done for you? How has Wright/ Hope helped/hindered you as a person? 
Hailey: Second Interview

1. Did you have any difficulties when you were at Gable? How could things have been better for you?

2. Why do you think you're a better student at Hope?

3. When you said teachers here explain things really good, what do you mean?

4. Why do you think that students have better relationships with teachers at Hope? Why do you think you have better grades?

5. You said that you don't talk to a social worker here, because you don't really need one? Why do you think that is?

6. I know you took an anger management class for probation and that helped you. Is there anything else Hope does that helps you to stay out of trouble and deal with conflict?

7. What makes you nervous about going to East? What are you doing about your worries? Are you seeking any help?

8. I'm trying to get an overall perspective of your experiences in both Gable and Hope. What do you think of your experience at Gable overall? What about at Hope?

9. You seem pretty satisfied with the progress you have made at Hope. Why do you think you have made that kind of progress?

a. Do you think you could have done better? How?

b. What did Hope provide that was essential to your progress?

c. Do you think you could have done this well at Gable?

d. What else did Wright need to do for you to do better there?

10. What are some of the things that Gable did really well?

a. Offer that Hope does not? 
b. Opportunities that you may feel like you missed?

11. In my last interviews, students identified teachers who care, structure, fair treatment, being able to get help when they need it as key elements to their success. How did Hope address those things? How did Gable?

12. What have you accomplished that you are proud of? How would this be different if you weren't at Hope?

13. How would you change Hope if you could? Do you think that would make it better or weaker? How would you change Gable if you could?

14. What has Hope done to make you more successful in academics, behavior, and teacher relationships?

15. Think about high school as preparing you for life. How has Hope prepared you for life? Can you think about how this might be different if you had stayed at Gable?

16. What is the most important thing that Gable / Hope has done for you? How has Gable / Hope helped/hindered you as a person? 
Isaiah: Second Interview

1. Now that you have had more time at Hope, what's your favorite part?

2. Are you having any difficulties here? What are they doing to help you?

3. Talk to me more about the people here. Have you identified people you might talk to if needed? How are your relationships with adults here? Peers?

4. What do you do in your resource class? How does that help you? Do you need it?

5. What are some things you miss from Gable?

6. Besides Mr. Mears, have you met anyone here who has been helpful?

7. Tell me about a teacher at Gable that you had a good relationship with?

8. How have teachers related to you at Hope - at a better level, like you thought?

9. You told me that you didn't try hard at Gable. Is that different here (since it's your last stop)? Why /why not?

10. You said that the changes you needed to make are turning in work and being respectful to teachers. How are those things going for you?

11. I'm trying to get an overall perspective of your experiences in both Gable and Hope. What do you think of your experience at Gable overall? What about at Hope?

12. You seem pretty satisfied with the progress you have made at Hope. Why do you think you have made that kind of progress?

a. Do you think you could have done better? How? 
b. What did Hope provide that was essential to your progress?

c. Do you think you could have done this well at Gable?

d. What else did Gable need to do for you to do better there?

13. What are some of the things that Gable did really well?

a. Offer that Hope does not?

b. Opportunities that you may feel like you missed?

14. In my last interviews, students identified teachers who care, structure, fair treatment, being able to get help when they need it as key elements to their success. How did Hope address those things? How did Wright?

15. What have you accomplished that you are proud of? How would this be different if you weren't at Hope?

16. How would you change Hope if you could? Do you think that would make it better or weaker? How would you change Gable if you could?

17. What has Hope done to make you more successful in academics, behavior, and teacher relationships?

18. Think about high school as preparing you for life. How has Hope prepared you for life? Can you think about how this might be different if you had stayed at Gable?

19. What is the most important thing that Gable / Hope has done for you? How has Wright/ Gable helped/hindered you as a person? 
Luke: Second Interview

1. Have you had any academic or behavioral difficulties at Gable or Hope?

2. Who was your favorite teacher at Gable? Why was she your favorite? What made that a good relationship? (same for Hope).

3. You said that Gable helped you work through things. Can you give me an example?

4. What would have helped you get better grades at Gable? Have better attendance?

5. Why do you think you're doing better here than at Gable?

a. Why did you skip there but not here?

6. What do you miss about Gable?

7. I'm trying to get an overall perspective of your experiences in both Gable and Hope. What do you think of your experience at Gable overall? What about at Hope?

8. You seem pretty satisfied with the progress you have made at Hope. Why do you think you have made that kind of progress?

a. Do you think you could have done better? How?

b. What did Hope provide that was essential to your progress?

c. Do you think you could have done this well at Gable?

d. What else did Gable need to do for you to do better there?

9. What are some of the things that Gable did really well?

a. Offer that Hope does not?

b. Opportunities that you may feel like you missed?

10. In my last interviews, students identified teachers who care, structure, fair treatment, being able to get help when they need it as key elements to their success. How did Hope address those things? How did Gable? 
11. What have you accomplished that you are proud of? How would this be different if you weren't at Hope?

12. Would you have graduated from Gable if you had stayed there? Why/why not?

13. Are you sorry that you didn't return to Gable? Why/why not?

14. How would you change Hope if you could? Do you think that would make it better or weaker? How would you change Gable if you could?

15. What has Hope done to make you more successful in academics, behavior, and teacher relationships?

16. Think about high school as preparing you for life. How has Hope prepared you for life? Can you think about how this might be different if you had stayed at Gable?

17. What is the most important thing that Gable / Hope has done for you? How has Gable / Hope helped/hindered you as a person? 
Zach: Second Interview

1. What kinds of obstacles has Hope helped you with?

2. Why do you think Adams offered you the opportunity to attend Hope? What did you see in the brochures that made you think this would be a good place for you?

3. I'm trying to get an overall perspective of your experiences in both Adams and Hope. What do you think of your experience at Adams overall? What about at Hope?

4. You seem pretty satisfied with the progress you have made at Hope. Why do you think you have made that kind of progress?

a. Do you think you could have done better? How?

b. What did Hope provide that was essential to your progress?

c. Do you think you could have done this well at Adams?

d. What else did Adams need to do for you to do better there?

5. What are some of the things that Adams did really well?

a. Offer that Hope does not?

b. Opportunities that you may feel like you missed?

6. You said that you liked Adams because it was big and had a lot of opportunities but Hope because it is small and teachers can focus more on students. Which is more effective for you?

7. In my last interviews, students identified teachers who care, structure, fair treatment, being able to get help when they need it as key elements to their success. How did Hope address those things? How did Adams?

8. What have you accomplished that you are proud of? How would this be different if you weren't at Hope? 
9. How would you change Hope if you could? Do you think that would make it better or weaker? How would you change Adams if you could?

10. What has Hope done to make you more successful in academics, behavior, and teacher relationships?

11. Think about high school as preparing you for life. How has Hope prepared you for life? Can you think about how this might be different if you had stayed at Adams?

12. What is the most important thing that Adams / Hope has done for you? How has Adams / Hope helped/hindered you as a person? 


\section{APPENDIX C}

THIRD INTERVIEW PROTOCOLS 
Andrea: Third Interview

1. What did East do for you that was especially effective in helping you be successful? Hope?

2. Which classes were most difficult for you at East? At Hope?

3. What did East/ Hope do to help you in those classes?

4. Why do you think your grades are so much better at Hope? Behavior?

5. You have said a few times that it helps you that Hope is a smaller setting. Why do you think that helps you?

6. Why do you care more about grades now?

7. What kind of things have you learned at Hope that will help you with your life?

8. You said that having teachers who care is important to your success. How is that different at East and Hope? Which has been more effective for you?

9. You said that structure in the environment is important to your success. How is the structure different at Hope and East? Which has been more effective for you?

10. You said that fair treatment is sort of important to your success. How did fair treatment help you at East? At Hope? Examples?

11. You said that being able to get help when you need it is important to your success. How did being able to get help when you need it help you at East? At Hope? Examples?

12. How do you know that you have been successful at Hope? 
Bobby: Third Interview

1. What did Mitchell do for you that was especially effective in helping you be successful? Hope?

2. Which classes were most difficult for you at Mitchell? At Hope?

3. What did Mitchell / Hope do to help you in those classes?

4. Why do you think your grades are so much better at Hope? Behavior?

5. You have said a few times that it helps you that Hope is a smaller setting. Why do you think that helps you?

6. Why do you care more about grades now?

7. What kind of things have you learned at Hope that will help you with your life?

8. You said that having teachers who care is important to your success. How is that different at Mitchell and Hope? Which has been more effective for you?

9. You said that structure in the environment is important to your success. How is the structure different at Hope and Mitchell? Which has been more effective for you?

10. You said that fair treatment is sort of important to your success. How did fair treatment help you at Mitchell? At Hope? Examples?

11. You said that being able to get help when you need it is important to your success. How did being able to get help when you need it help you at Mitchell? At Hope? Examples? 
12. How do you know that you have been successful at Hope? 
Evan: Third Interview

1. What did Wright do for you that was especially effective in helping you be successful? Hope?

2. Why do you think your grades are so much better at Hope? Behavior?

3. You have said a few times that it helps you that Hope is a smaller setting. Why do you think that helps you?

4. Why do you care more about grades now?

5. What kind of things have you learned at Hope that will help you with your life?

6. You said that having teachers who care is important to your success. How did having teachers who care help you at Wright? At Hope? Examples?

7. Why do you think that teachers at Hope nag you so much?

8. Is being able to get help when you need it important to your success. How did being able to get help when you need it help you at Wright? At Hope?

Examples?

9. Do you think that fair treatment is important to your success? As it relates to getting the help you need? How did fair treatment help you at Wright? At Hope? Examples?

10. You said that structure in the environment is important to your success. How did structure in the environment help you at Wright? At Hope? Examples? 
Hailey: Third Interview

1. What did Gable do for you that was especially effective in helping you be successful? Hope?

2. Which classes were most difficult for you at Gable? At Hope?

3. What did Gable/ Hope do to help you in those classes?

4. Why do you think your grades are so much better at Hope? Behavior?

5. You have said a few times that it helps you that Hope is a smaller setting. Why do you think that helps you?

6. Why do you care more about grades now?

7. What kind of things have you learned at Hope that will help you with your life?

8. You said that having teachers who care is somewhat important to your success. How did having teachers who care help you at Gable? At Hope? Examples?

9. You said that structure in the environment is important to your success. How did structure in the environment help you at Gable? At Hope? Examples?

10. You said that fair treatment is important to your success. How did fair treatment help you at Gable? At Hope? Examples?

11. You said that being able to get help when you need it is important to your success. How did being able to get help when you need it help you at Gable? At Hope? Examples? 
Isaiah: Third Interview

1. You talked about your resource class at Hope being helpful to you. Can you talk about some of the things that Mrs. (resource teacher) does that are really helpful?

2. Did you have a resource class at Gable?

3. What did Gable do for you that was especially effective in helping you be successful? Hope?

4. You told me that you changed when you came to Hope? How did you change? Why?

5. Which classes were most difficult for you at Gable? At Hope?

6. What did Gable/ Hope do to help you in those classes?

7. Why do you think your grades are so much better at Hope? Behavior?

8. You have said a few times that it helps you that Hope is a smaller setting. Why do you think that helps you?

9. Why do you care more about grades now?

10. What have you learned here that will help you when you return to Gable? How did you learn it? Why did it take you coming to Hope to learn that?

11. What kind of things have you learned at Hope that will help you with your life?

12. You said that having teachers who care is important to your success. How did having teachers who care help you at Gable? At Hope? Examples? 
13. Why do you think that teachers at Hope nag you so much?

14. You said that being able to get help when you need it is important to your success. How did being able to get help when you need it help you at Gable? At Hope? Examples?

15. You said that fair treatment is important to your success. How did fair treatment help you at Gable? At Hope? Examples?

16. You said that structure in the environment is important to your success. How did structure in the environment help you at Gable? At Hope? Examples? 
Luke: Third Interview

1. What did Gable do for you that was especially effective in helping you be successful? Hope?

2. Which classes were most difficult for you at Gable? At Hope?

3. What did Gable/ Hope do to help you in those classes?

4. Why do you think your grades are so much better at Hope? Behavior?

5. You have said a few times that it helps you that Hope is a smaller setting. Why do you think that helps you?

6. Why do you care more about grades now?

7. What kind of things have you learned at Hope that will help you with your life?

8. Why did you make such a major change in your attendance when you came to Hope?

9. You said that having teachers who care is not important to your success, but you also said that teacher's here push you to do your work, and they wouldn't if they didn't care. Do you think you needed that push? Did you get that at Gable? At Hope? Examples?

10. You said that structure in the environment is not important to your success. How is the structure different at Hope and Gable? Which has been more effective for you?

11. You said that fair treatment is sort of important to your success. How did fair treatment help you at Gable? At Hope? Examples? 
12. You said that being able to get help when you need it is important to your success. How did being able to get help when you need it help you at Gable? At Hope? Examples?

13. How do you know that you have been successful at Hope? 
Zach: Third Interview

1. What did Adams do for you that was especially effective in helping you be successful? Hope?

2. Why do you think your grades are so much better at Hope? Behavior?

3. You have said a few times that it helps you that Hope is a smaller setting. Why do you think that helps you?

4. Why do you care more about grades now?

5. What kind of things have you learned at Hope that will help you with your life?

6. You said that having teachers who care is important to your success. How did having teachers who care help you at Adams? At Hope? Examples?

7. Is being able to get help when you need it important to your success. How did being able to get help when you need it help you at Adams? At Hope? Examples?

8. Do you think that fair treatment is important to your success? As it relates to getting the help you need? How did fair treatment help you at Adams? At Hope? Examples?

9. You said that structure in the environment is important to your success. How did structure in the environment help you at Adams? At Hope? Examples? 